\title{
Archaeological Investigations Along James Bayou in Marion County, Texas and Caddo Parish, Louisiana
}

Timothy K. Perttula

Heritage Research Center, Stephen F. Austin State University

Bo Nelson

Heritage Research Center, Stephen F. Austin State University

Claude McCrocklin

Follow this and additional works at: https://scholarworks.sfasu.edu/ita

Part of the American Material Culture Commons, Archaeological Anthropology Commons, Environmental Studies Commons, Other American Studies Commons, Other Arts and Humanities Commons, Other History of Art, Architecture, and Archaeology Commons, and the United States History Commons

Tell us how this article helped you.

This Article is brought to you for free and open access by the Center for Regional Heritage Research at SFA ScholarWorks. It has been accepted for inclusion in Index of Texas Archaeology: Open Access Gray Literature from the Lone Star State by an authorized editor of SFA ScholarWorks. For more information, please contact cdsscholarworks@sfasu.edu. 
Archaeological Investigations Along James Bayou in Marion County, Texas and Caddo Parish, Louisiana

\section{Creative Commons License}

\section{(c) (1) (8)}

This work is licensed under a Creative Commons Attribution-NonCommercial 4.0 International License 


\title{
Archaeological Investigations Along James Bayou in Marion County, Texas and Caddo Parish, Louisiana
}

\author{
Timothy K. Perttula and Bo Nelson, with contributions by Claude McCrocklin
}

\section{INTRODUCTION}

This is a report on archaeological investigations conducted along James Bayou in Marion County, Texas, and Caddo Parish, Louisiana, between 19911993. This work was done primarily by Claude McCrocklin (Shreveport, Louisiana) and a large group of volunteers, some from the Northeast Texas Archeological Society and others from the Northwest Chapter of the Louisiana Archaeological Society, assisted by Perttula and Nelson on occasion. With the permission of McCrocklin, we analyzed the recovered artifacts and available notes/records/ site reports to prepare this article summarizing the archaeological findings of the project.

James Bayou, also known as Coushatta Jim's Bayou, Jim's Bayou, and Jeems Bayou (Bagur 2001:3), is an eastward and southward-flowing tributary to Big Cypress Bayou and Caddo Lake (Figure 1a-c). "On an upper portion of this bayou there was a small, deep lake formed by stream scour between bluffs that later came to be known as Monterey Lake. Before the 1800s, this was the only permanent lake in the region" (Bagur 2001:3). Caddo Lake at its maximum extent may have reached elevations (although fluctuating) between 173-180 feet amsl, based on historic maps, studies of lacustrine deposits on the lake bed, and relict shorelines (U.S. Department of the Interior 1914; Albertson and Dunbar 1993).

The main purpose of the archaeological investigations was to identify the location or locations of the early $19^{\text {th }}$ century Caddo Indian village known to have been situated in the vicinity of James Bayou (McCrocklin 1992a; see also Bagur 2001:37-44; Flores 1977, 1984), at the upper end of what was then Caddo Lake. The archaeological investigations reported on herein began in the Monterey Lake area of James Bayou.

During the course of these archaeological investigations, a number of archaeological sites were located along James Bayou, and the findings from these sites are discussed below (Figures 2 and 3).
"Several possible components of the [Caddo] village were located, but for one reason or another, no conclusive identifications could be made" (Parsons et al. 2002:15). McCrocklin, however, continued to periodically conduct archaeological survey and metal detecting investigations along James Bayou, and in 1998, he located several areas of an early $19^{\text {th }}$ century Caddo archaeological site (41MR211) on the south side of James Bayou (McCrocklin 1998). The location and character of this site is consistent with the historical and archival sources concerning the James Bayou Caddo village, that being "on a bayou or creek... which is navigable for pirogues only, within about six miles of their village, and that only in the rainy season" (Bagur 2001:37). This site in the recent archaeological literature has been identified as the site of Timber Hill or Sha'chahdinnih (Parsons et al. 2002; Bagur 2001), although other locations for that village south of Caddo Lake have been proposed by Tiller (2007, 2008). The Texas Historical Commission conducted excavations at one area (Area 3) of 41MR211 in 1999 (Parsons et al. 2002:17-22).

\section{INVESTIGATED SITES}

The archaeological investigations at the James Bayou sites (see Figures 2 and 3) consisted of several different approaches, including surface collections of visible artifacts, metal detector scans, shovel tests, and hand excavations of units; the latter was done only at the Monterey Lake site (41MR77) in work done on January 16, 1993. The majority of the work consisted of metal detector scans, followed by the rapid excavation of small areas to investigate the metal detector findings. In most cases, the location of those metal detector scans within each of the sites was not recorded or formally mapped, although in some instances, the depth of the metal detector scan excavations was noted. 


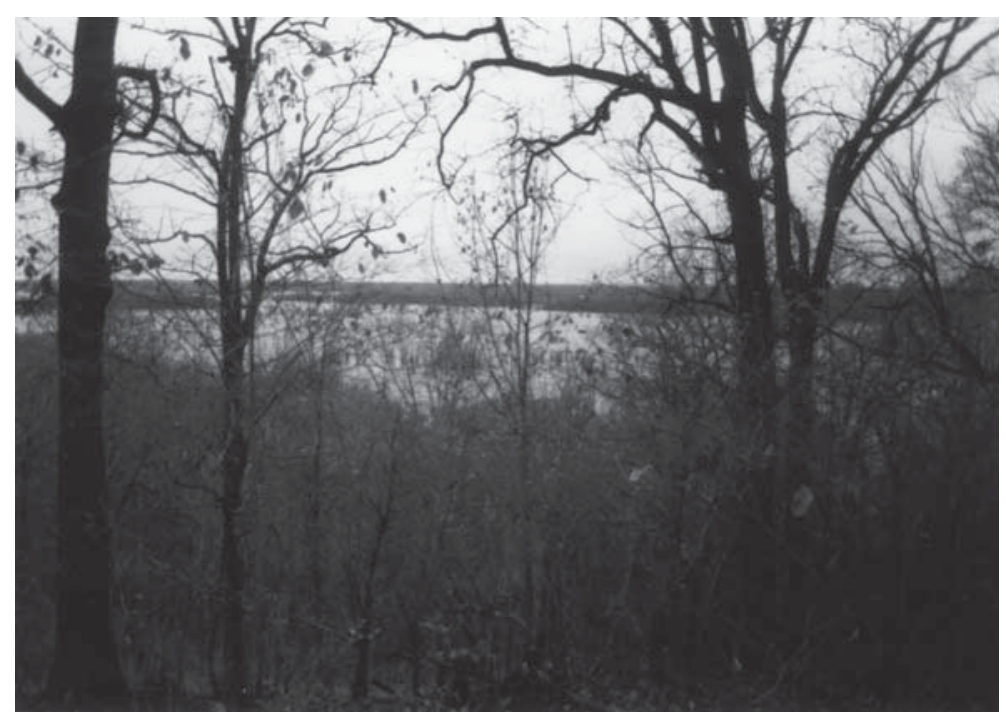

a

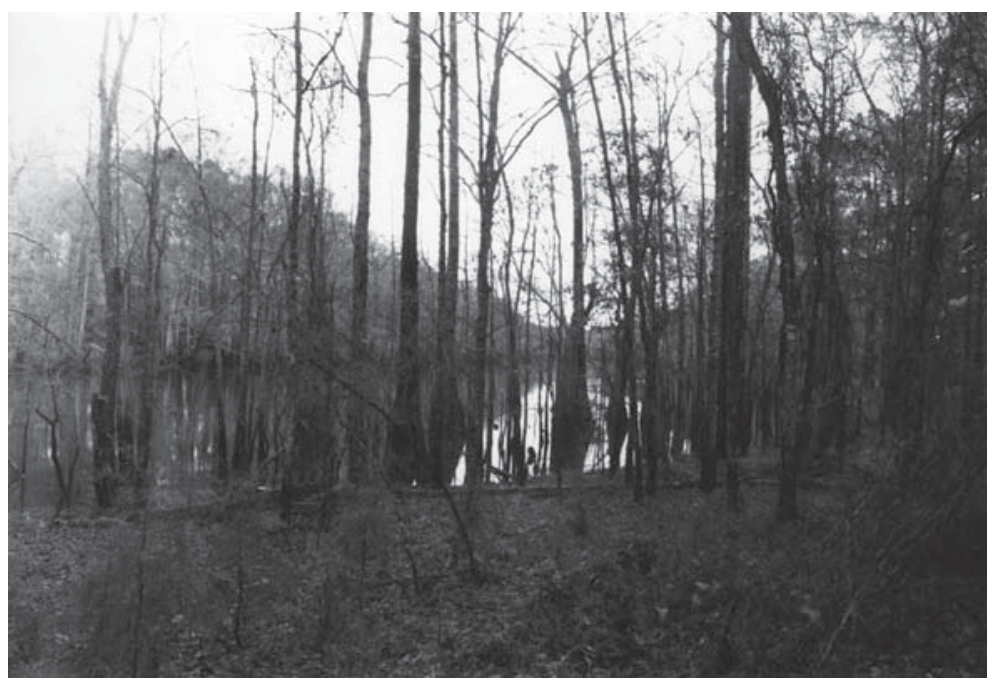

b

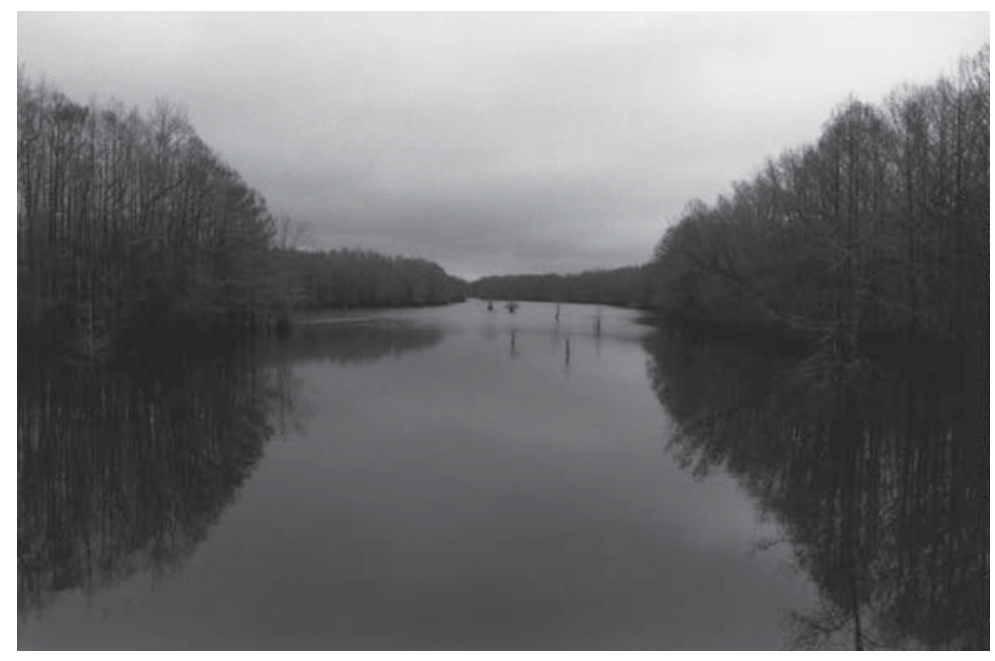

C

Figure 1. James Bayou and Caddo Lake: a, Caddo Lake, in the vicinity of Potter's Point, looking south; b, James Bayou immediately below Monterey Lake; c, James Bayou in Louisiana, downstream from Monterey Lake. 


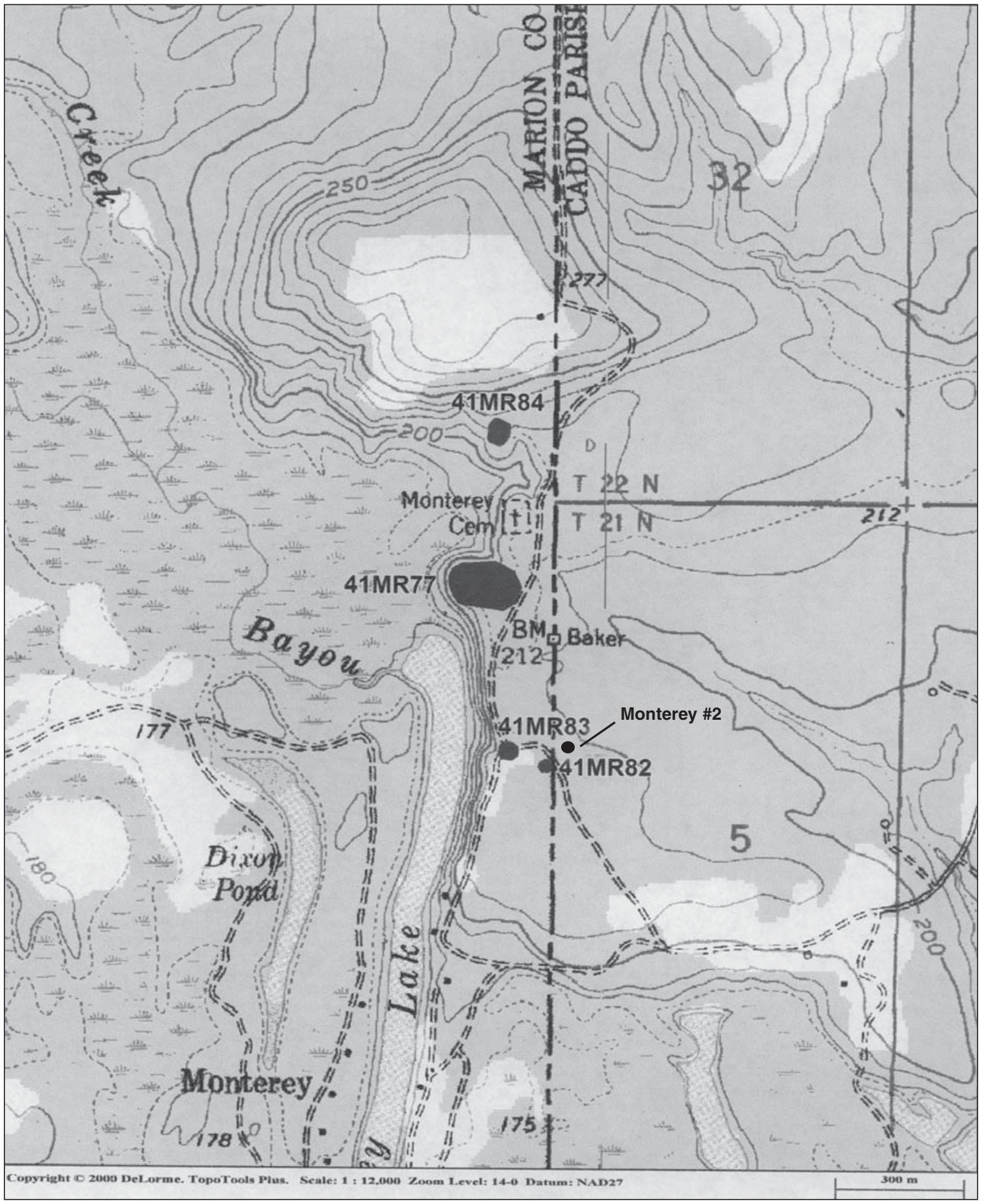

Figure 2. Sites recorded in the vicinity of Monterey Lake in Marion County, Texas, and Caddo Parish, Louisiana. Trees 7.5' USGS topographic quadrangle. 


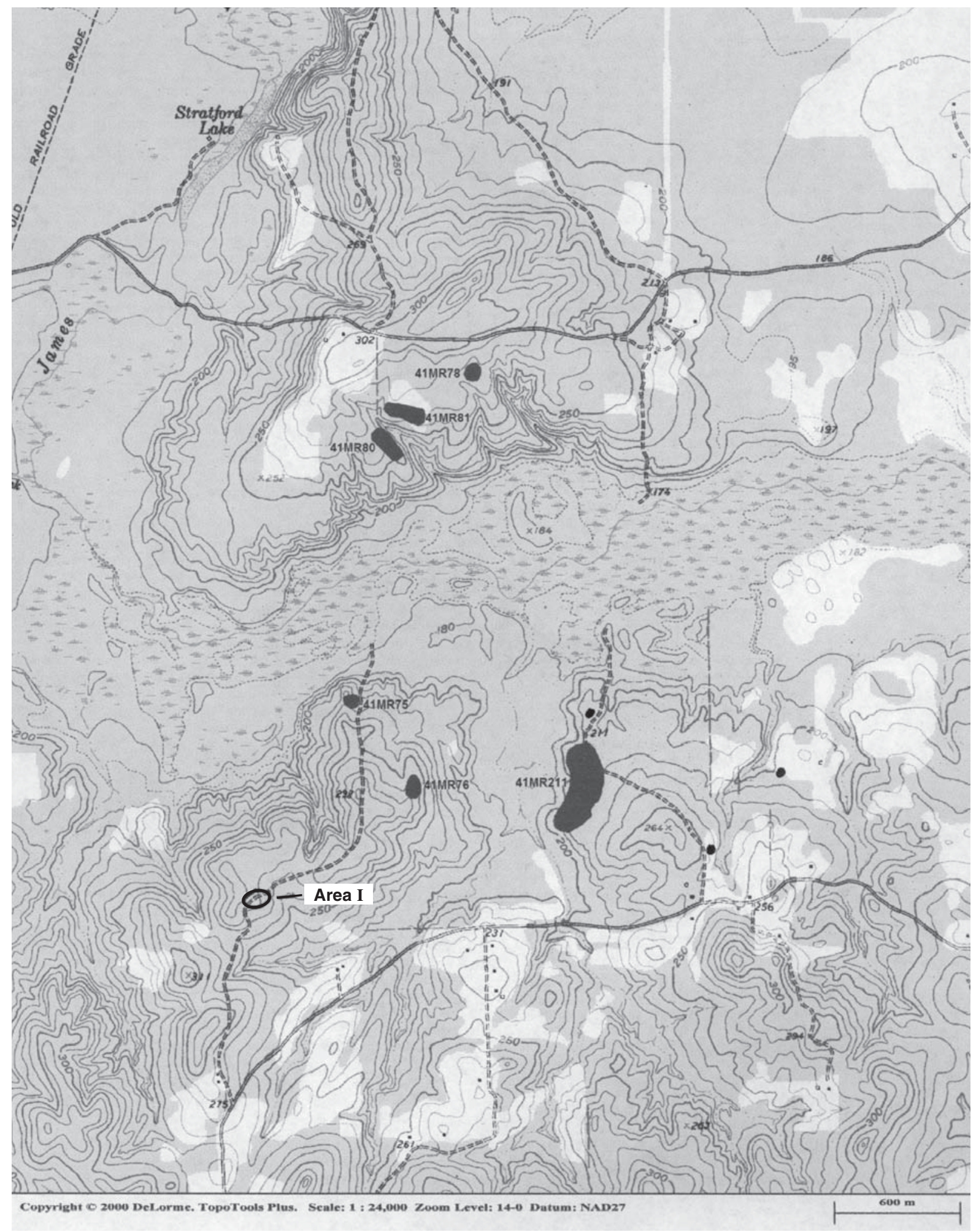

Figure 3. Other sites recorded along James Bayou, upstream from Monterey Lake, in Marion County, Texas, including 41MR211, Areas 1-5. Trees 7.5' USGS topographic quadrangle. 


\section{Clements Field (41MR75)}

The Clements Field site (see Figure 3) is located on a ridge toe slope (220-230 ft. amsl) on the south side of the James Bayou valley, overlooking a swampy floodplain. Only surface collections were completed at the Clements Field site. The recovered artifacts indicate that the site is multi-component, with evidence for both prehistoric and $19^{\text {th }}$ century historic occupations on the same landform.

The first component is a Late Caddo period (ca. A.D. 1400-1680) occupation marked by 13 decorated ceramic sherds. Most of the sherds are from brushed $(n=6)$, brushed-punctated $(n=1)$, brushedappliqued $(\mathrm{n}=2)$, or brushed-appliqued-punctated $(n=1)$ utility war cooking jars. There is also one Sinner Linear Punctated sherd, another body sherd with parallel incised lines, and a carinated bowl rim sherd with a hatched vertical bracket or panel divider.

The second component dates to the early to mid-19th century. The few recovered artifacts include one sherd of colorless bottle glass and seven whiteware sherds. Four of these are plain, one is a blue annular ware, a second has a hand-painted green band, and the last decorated sherd is a green shell-edged piece, broken so that the rim form (cf. Hunter and Miller 1994) is unknown. Given that in general green shell-edged plates began to diminish in frequency after 1800 relative to blue shell-edged plates (Sussman 2000:51) suggests this ceramic plate may have been discarded on the site in the early part of the 19th century.

\section{MR76}

41 MR76 is situated on a broad upland ridge (260-290 feet amsl) on the south side of the James Bayou valley (see Figure 3). There are two areas of artifacts and features at 41MR76 (see Figure 3 and McCrocklin 1992b). In Area I a single historic $19^{\text {th }}$ century feature was identified in a forest road that consisted of a chimney fall from a log cabin. After clear cutting, a second area of the site (Area II) was discovered well to the north of Area I. In the latter area, after surface collections, metal detector scans, and the screening of sediments from investigating metal detector hits was done in January and February 1992 , four $19^{\text {th }}$ century features were identified here (Figure 4). The features included a chimney fall from a $\log$ cabin (Feature 1), a well (Feature 2), a possible small root cellar (Feature 3 ), and a midden deposit (Feature 4).
The recovered artifacts from Area II at 41MR76 are listed in Table 1 . The most abundant kinds of artifacts are machine cut nails (1820-1891) from wood house construction, and ceramic plates and glass bottles from kitchen/domestic activities. These latter kinds of artifacts are commonly seen on early to mid-19 ${ }^{\text {th }}$ century farmsteads in Northeast Texas.

The 24 refined earthenware ceramics from the site are whiteware (post-1830) sherds from plates and bowls (see Table 1). The decorated sherds include three floral green transfer-printed, five annular ware with an earthen-colored palette (i.e., white, black, yellow, earthen blue, suggesting earlier annular wares, cf. Price 1979:18), and one blue transferprinted sherd with hand-painted red flowers over the transfer print; this latter decorative combination is seen in ca. 1840-1860 whiteware ceramics (Perttula 1989:74-75). The range of production of green transfer-printed wares is $1818-1859$ with mean beginning and end production dates of 1830 to 1846 (Samford 2000:Table 5).

The stoneware sherds (see Table 1) are from two different alkaline-glazed stoneware crocks (ca. 1839-1875) that were probably manufactured in a Northeast Texas stoneware kiln. One stoneware sherd is a ca. 1870s brown lead-glazed handle from a crock or jar.

McCrocklin (1992b) noted that a single sherd of French faience was recovered from Area II at the site, although from what context is not known. A slide of the sherd provided by Claude McCrocklin suggests that the sherd is a piece, probably from a plate, of Faience Brune (Avery et al. 2007:Figures 25 and 26). According to Avery et al. (2007:467), Faience Brune is most common in northwestern Louisiana sites between 1770-1820, and began to be replaced by hard paste English ceramics after 1800 . Faience Brune has also been found in similar temporal contexts in sites in the Nacogdoches area of East Texas (see Perttula 2008). The occurrence of faience at $41 \mathrm{MR} 76$ suggests that the site may have been first settled or used by a group of Caddo in the late $18^{\text {th }}$ to early $19^{\text {th }}$ century, perhaps contemporaneously with the earliest occupation at nearby 41MR211; no faience was recovered from there, however (Parsons et al. 2002:43). The second, and most substantial (based on the whiteware sherds), occupation took place beginning about 1840 .

The bottle glass from 41MR76, Area II ( $n=13)$ includes sherds from at least four bottles (see Table 1 ); one of these melted from exposure to a fire. Most of the sherds are from hand-blown dark green 


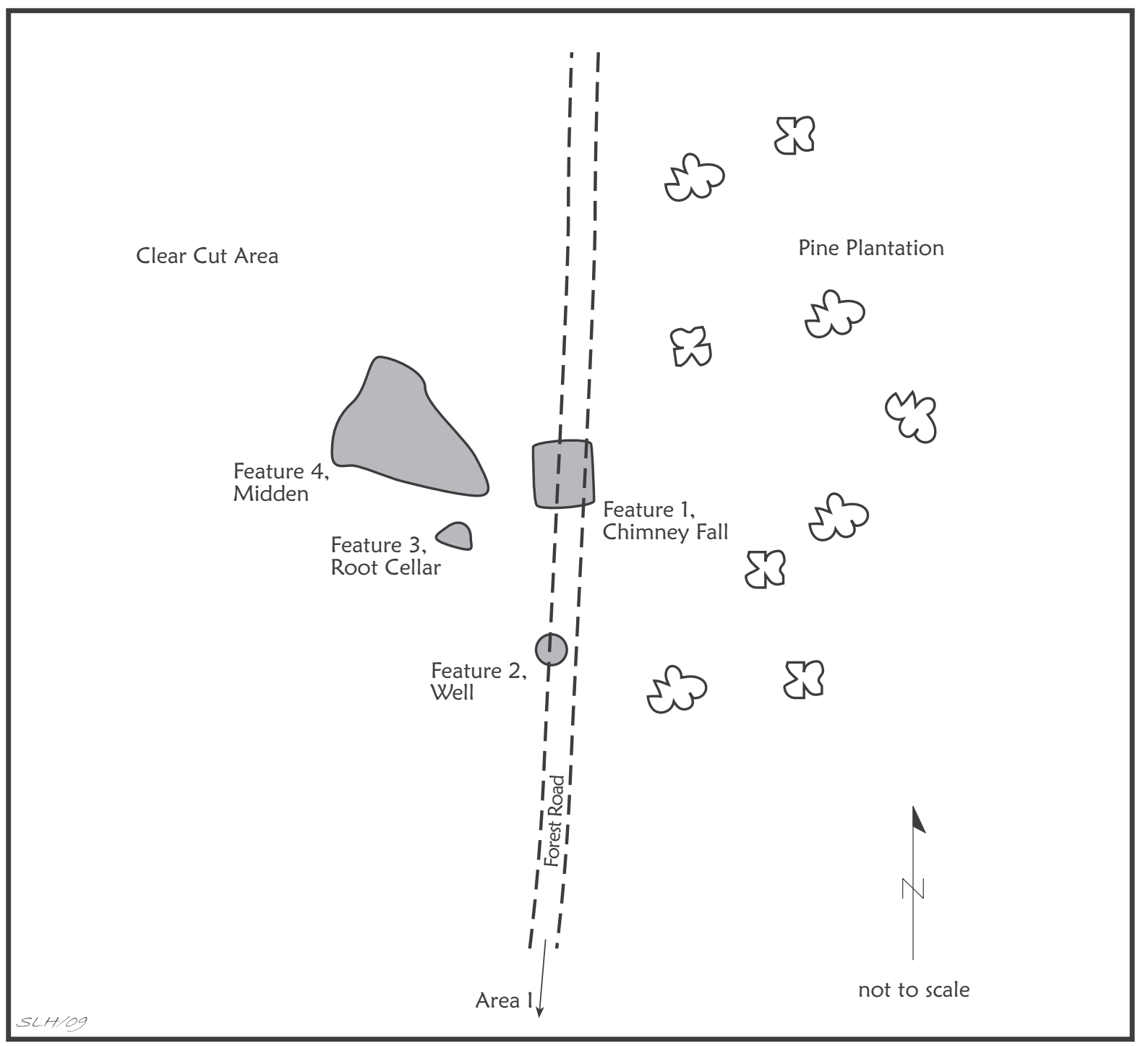

Figure 4. Map of Area II at 41MR76.

wine bottles ( $n=9)$, including two applied lips; the remainder are colorless bottle sherds $(n=4)$.

Several items of clothing are in the collections, including a ca. 1847-1880 silver military button, "Series D, Symmetrical Spread Eagle, Line Shield" (Wyckoff 1984:88), and two porcelain 4-hole buttons. The military button was made by the Scillfield Mfg. Company. A related clothing item is an iron ("WINDSOR") sewing machine pedal (see Table 1).

The inhabitants of the site had firearms, probably muskets, based on the recovery of a 0.31 caliber lead ball and a brass trigger guard (Figure 5a-b). Other metal artifacts include iron tools (knife, drill bit, hook, plow parts), horse equipment (circular iron ring), a cast iron kettle/pan lid, and an iron handle to a piece of cutlery (probably a fork).
There is apparently some use of 41MR76, Area II, during prehistoric times. The evidence of this consists of a mano/pitted stone and a smoothed hematite cobble, probably a mano (see Table 1 ).

\section{Monterey Lake Site (41MR77)}

Most of the investigations during the James Bayou archaeological investigations took place at the Monterey Lake site (41MR77). The Monterey Lake site is on a wooded alluvial terrace (210-212 feet amsl) on the east side of James Bayou (Figure 6), at the northern end of Monterey Lake (see Figure 2); the Monterey cemetery lies a short distance to the north. This archaeological work included October 1991 metal detector scans, units excavated and screened 
Table 1. Recovered artifacts from 41MR76, Area II.

\begin{tabular}{|c|c|c|}
\hline Artifact Type & No. & Comments \\
\hline metal military button & 1 & ca. 1847-1880 (Wyckoff 1984:88) \\
\hline porcelain buttons & 2 & \\
\hline decorated whiteware sherds & 9 & \\
\hline plain whiteware sherds & 15 & \\
\hline alkaline-glazed stoneware sherds & 3 & \\
\hline lead-glazed stoneware sherds & 1 & \\
\hline bottle glass sherds & 13 & 2 melted \\
\hline cupreous strap handle & 1 & cut nail punched holes \\
\hline lead ball & 1 & 0.31 caliber \\
\hline brass trigger guard & 1 & \\
\hline machine cut nails & 17 & \\
\hline iron sewing machine pedal & 1 & "Windsor" \\
\hline iron knife blade & 1 & \\
\hline iron handle & 1 & for a fork? \\
\hline iron drill bit & 1 & \\
\hline iron kettle/pan lid & 1 & \\
\hline iron utility hook & 1 & \\
\hline iron nut & 1 & \\
\hline iron ring & 1 & horse gear \\
\hline cast iron piece & 2 & embossed with "E" and "IA" \\
\hline iron plow parts & 2 & \\
\hline unidentified iron piece & 1 & with tacks \\
\hline aluminum strap & 1 & \\
\hline hematite cobble & 1 & smoothed \\
\hline mano/pitted stone & 1 & \\
\hline Total & 80 & \\
\hline
\end{tabular}

to examine metal detector find areas and defined features (Features 1-3) in a midden deposit (Figure $7)$, extensive shovel testing ( $\mathrm{n}=33$ shovel tests) on January 16, 1993 (Figure 8a-b), and the excavation on that same day of a single unit (Figure 9a) adjacent to excavations in Feature 2 described by McCrocklin (1991). Thirty-one of the 33 shovel tests excavated at the Monterey Lake site had either historic $19^{\text {th }}$ century and aboriginal artifacts (see Figure 7).

The 1 x 1 m unit (Unit 1) excavated in 1993 in Feature 2 first encountered a concentration of wood charcoal and daub at $17 \mathrm{~cm}$ bs; the sediments at that depth were otherwise a dark brown sandy loam. Below this was a dark brown to black sandy loam pit fill that was first detected about $30 \mathrm{~cm}$ bs. There was a 3-4 cm thick lens of gray ash at the top of the pit (covering a maximum of at least a 50 x $50 \mathrm{~cm}$ area), and the pit itself extended to ca. 70 $\mathrm{cm}$ bs. It had sloping sides and a rounded base. The ash deposit ended at ca. $60 \mathrm{~cm}$ bs, above the base 


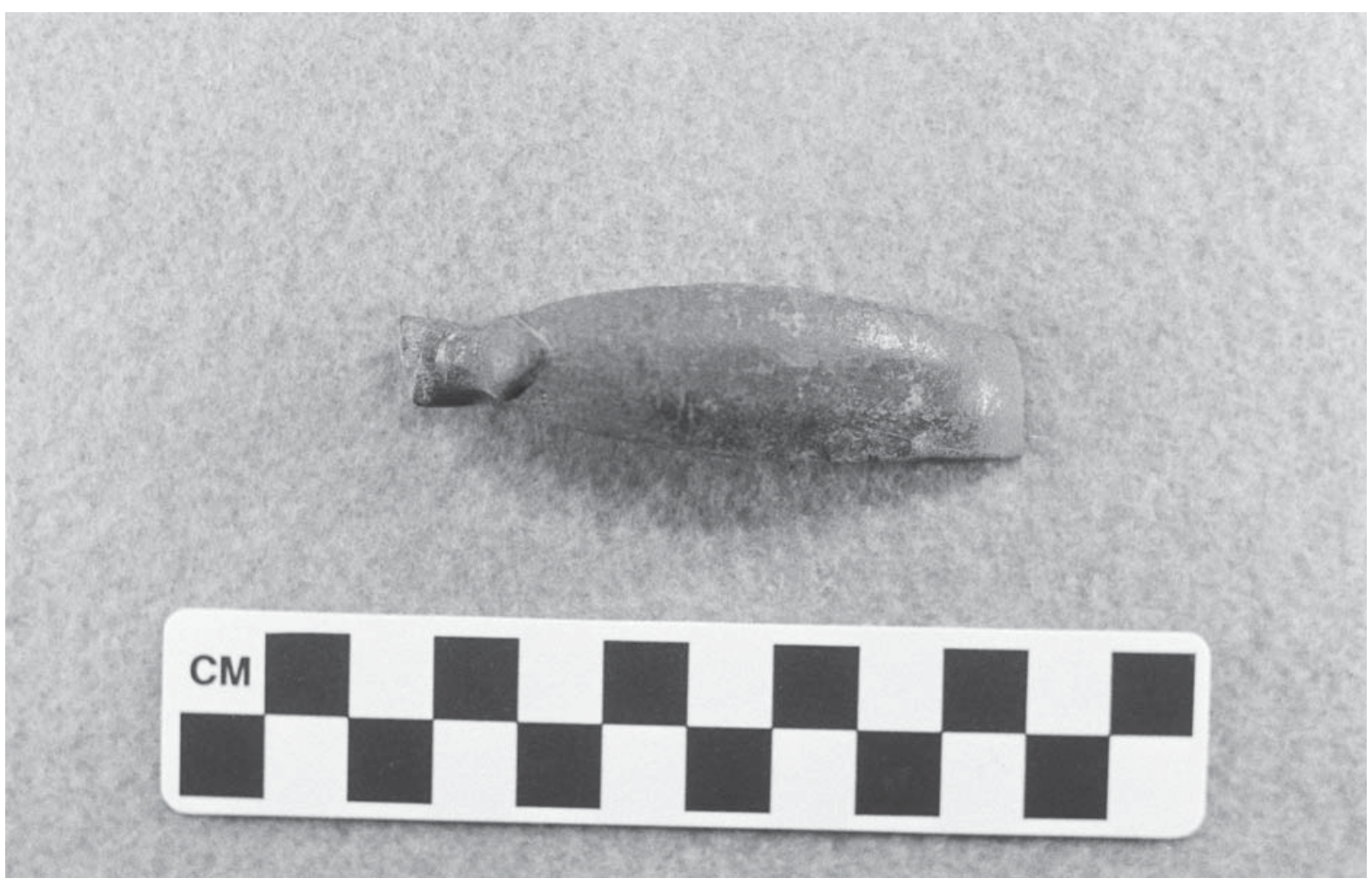

a

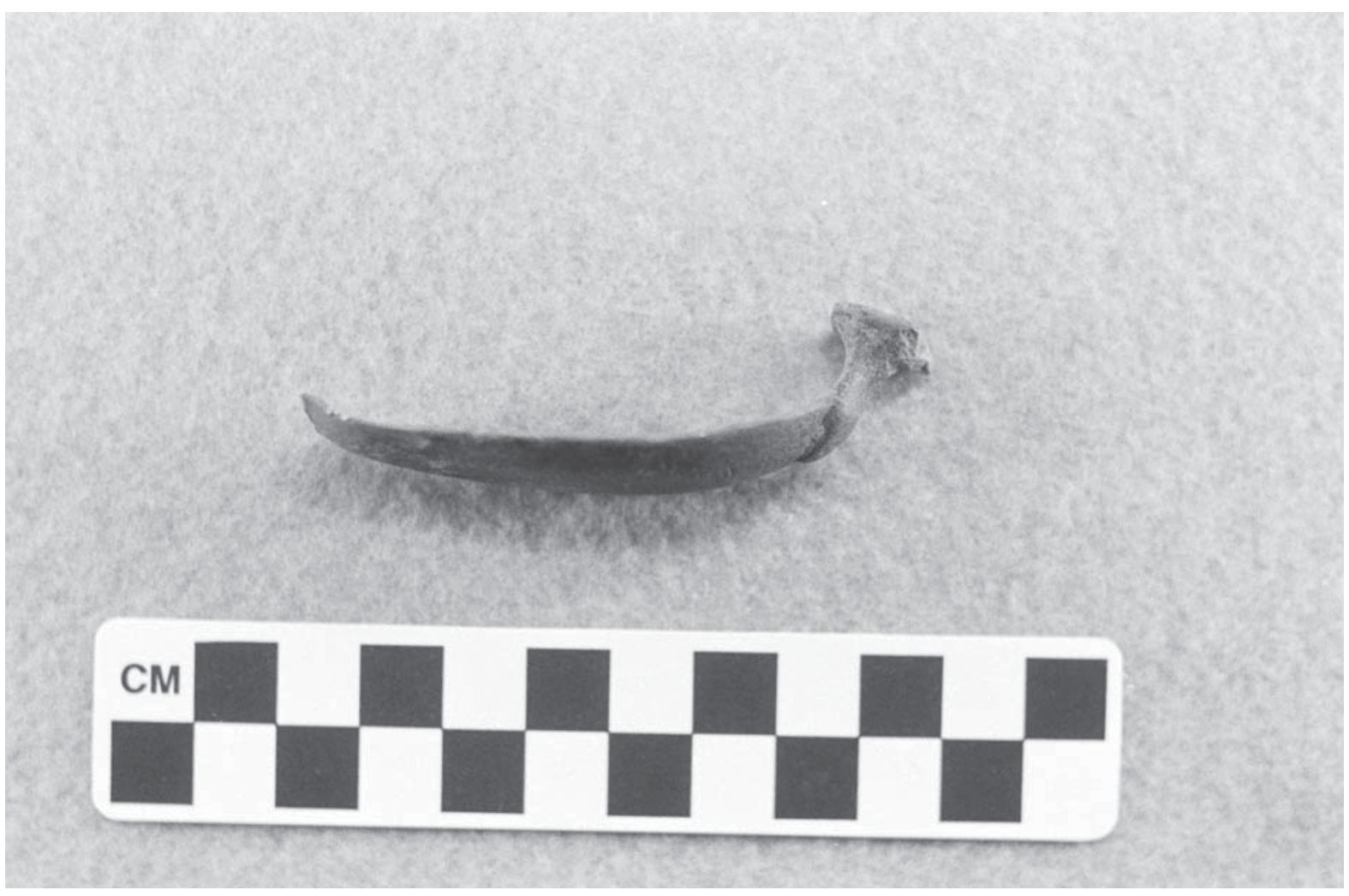

b

Figure 5. Brass trigger guard from 41MR76, Area II: a, front view; b, side view. 


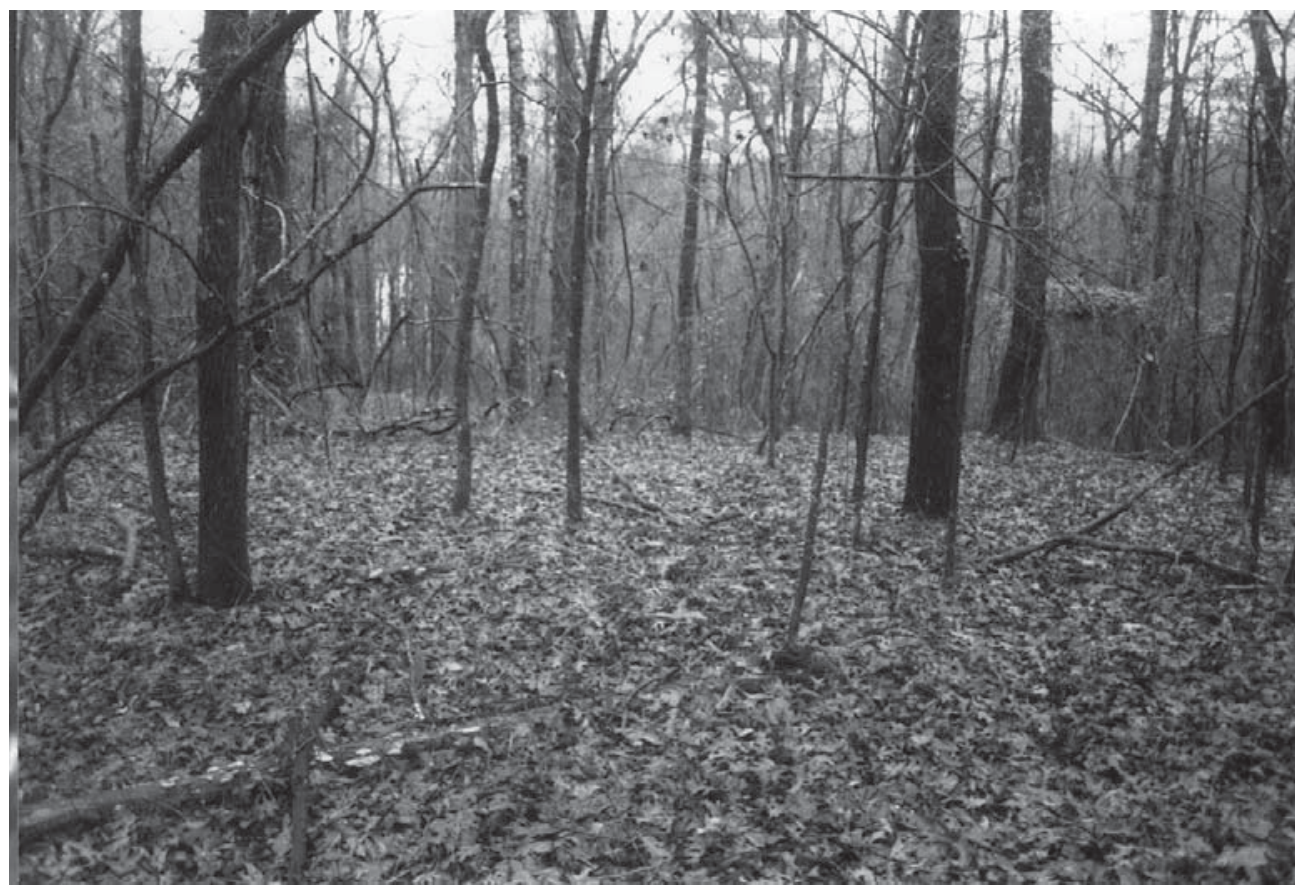

Figure 6. View south of the midden area at the Monterey Lake site, with Monterey Lake visible in the background.

of the pit. Outside of the midden deposits and pit features, the sediments were a light brown sandy loam E-horizon (Figure 9b).

A wide variety of historic artifacts $(n=2816)$ were recovered in the work at the Monterey Lake site, particularly from the investigations in two large trash pits (Features 1 and 2) in a midden deposit (see Figure 7). In addition, a large assortment of faunal remains was also found in the archaeological deposits (see below), although these remains have not been analyzed in any detail. The results of the shovel testing indicates that the $19^{\text {th }}$ century archaeological deposits at the site cover an area at least $56 \times 48 \mathrm{~m}$ in size (Figure $10 \mathrm{a}$ ), about 0.7 acres; the highest density of historic artifacts is in the central and northern part of the investigated site area, north of the midden deposits. Faunal remains from this historic occupation are primarily concentrated in the midden (Figure 10b). Aboriginal artifacts, particularly lithic debris, have almost the same distribution as the historic artifacts (Figure 10c), although the aboriginal artifacts at the Monterey Lake site appear to predate the historic occupation by at least 10 centuries or more (see below).

Two categories of historic artifacts dominate the $19^{\text {th }}$ century archaeological materials recovered from the Monterey Lake site during the 1991-1993 investigations: structural/architectural (34\%) and kitchen/domestic (55\%). The structural/architectural items include many cut nails (1820-1891, see Wells 2000), a few earlier, but large spike-like forged nails, iron spikes, hand-made brick, daub, mortar/ chinking, and window glass (Table 2). These suggest that the area of excavations at the Monterey Lake site was in the vicinity of a wood-framed building, or a log structure (or in the vicinity of an area where structural/architectural artifacts were discarded), that may have had a mud cat chimney (see Jordan 1978) on a brick base.

The few pieces of window glass suggest that at some time, this structure had a window installed in one or more of the walls. The range in pane thickness $(1.8-2.5 \mathrm{~mm})$ suggests the window pane was manufactured and installed after the mid-1860s (Moir 1987).

Due in part to the extensive use of metal detectors during much of the archaeological investigations, a wide variety of iron tools were found at the Monterey Lake site, including horse and stable gear (Table 3). The occupants of the site were well-supplied with the tools they needed to harvest timber, as well as engage in a number of other farm-related tasks, including maintaining wagons, employing and controlling horses and other livestock, working wood and bone, cutting cloth 


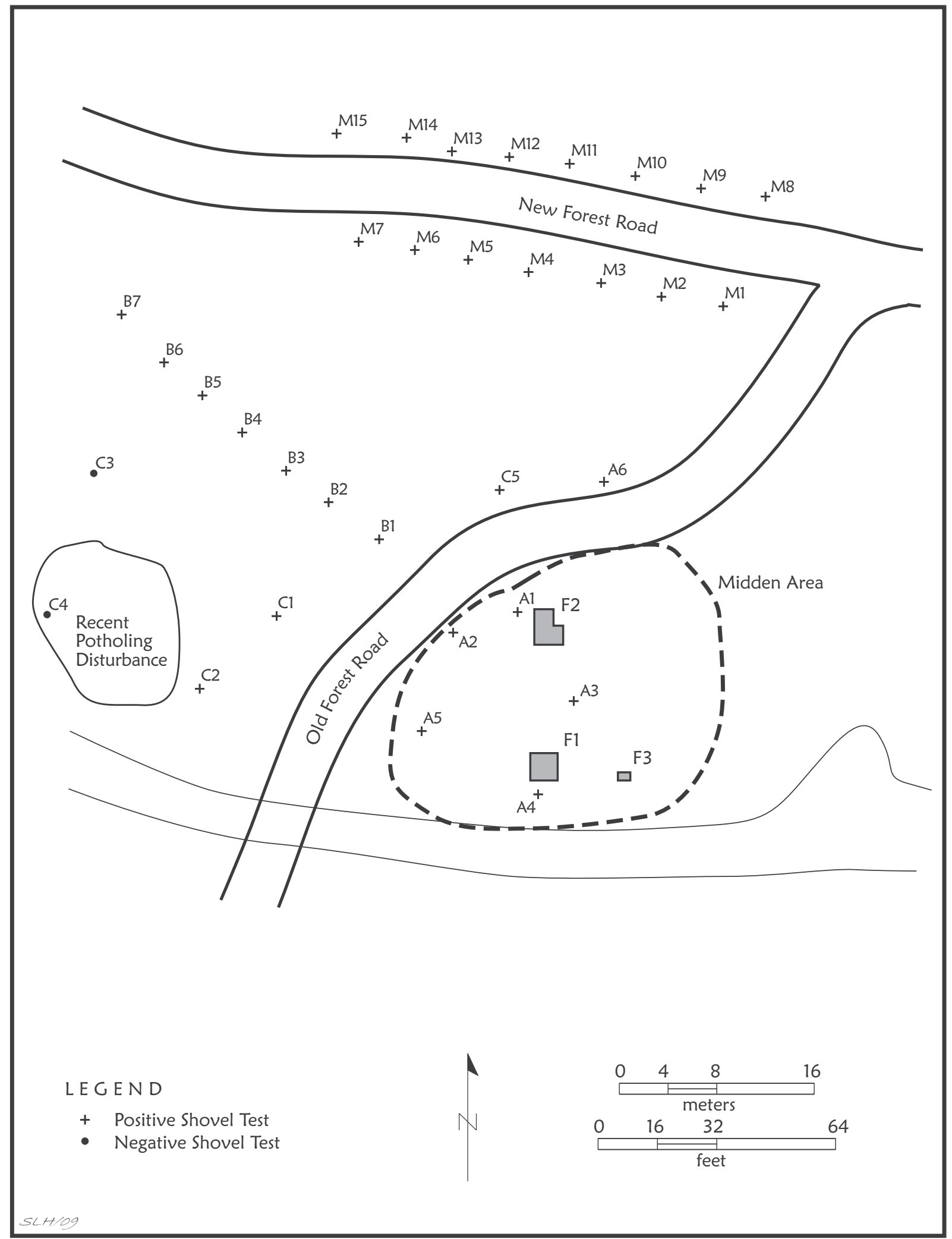

Figure 7. Map of the Monterey Lake site, with the midden area, excavation units, and shovel test locations. 


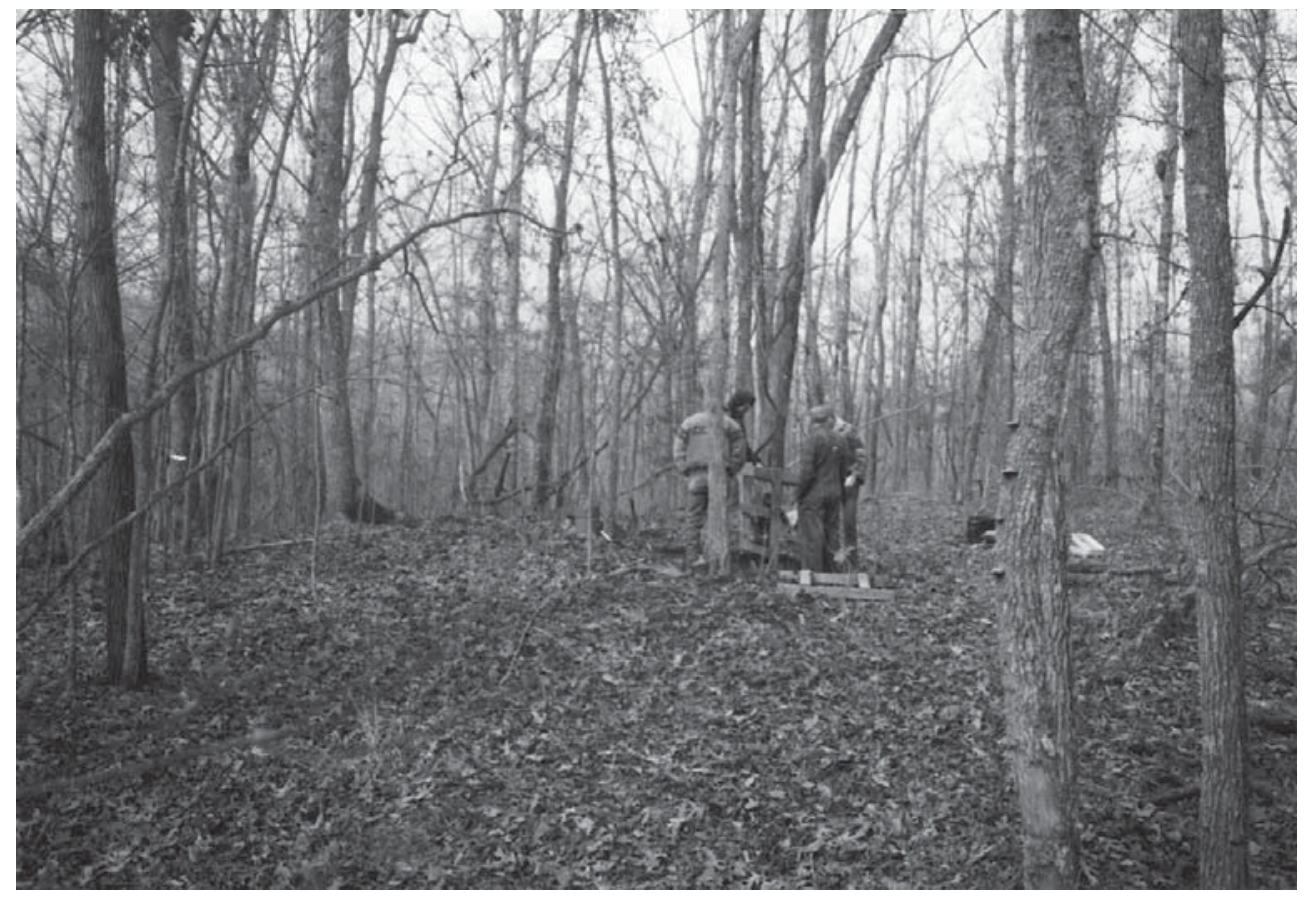

a

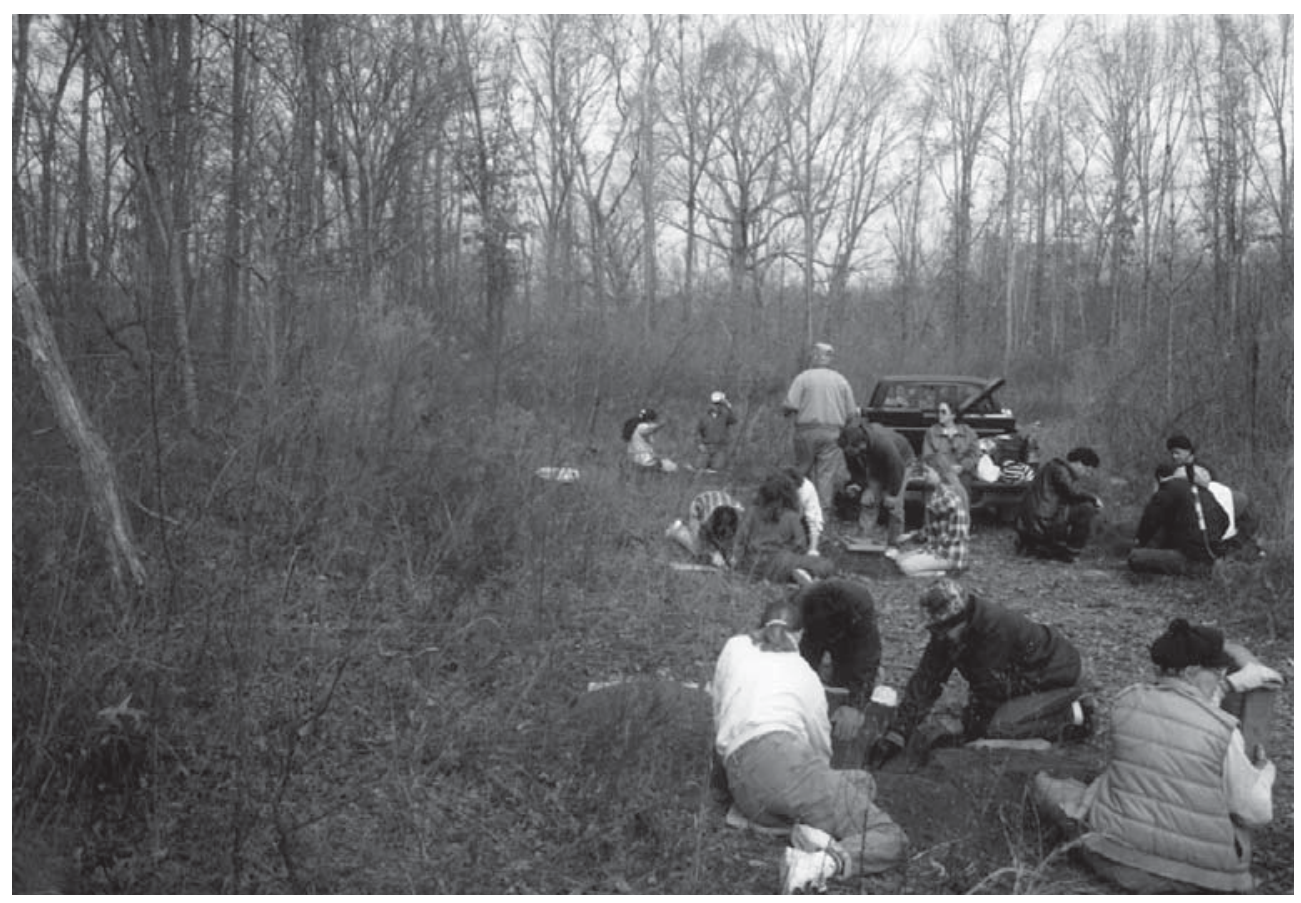

b

Figure 8. Shovel test investigations at the Monterey Lake site: $a$, in the midden area; $b$, the M line of shovel tests.

and leather, and bolting metal parts together. The most prevalent metal tool, horse, and stable artifacts include iron chain links, iron strips from working/ fabricating iron, and metal screws (Table 3).
There are also two large iron axes (Figure 11), an iron wedge, scissors, a barrel opener, iron case and butchering knives, including several with bone handles (Figure 12a-b), an iron fish hook (Figure 


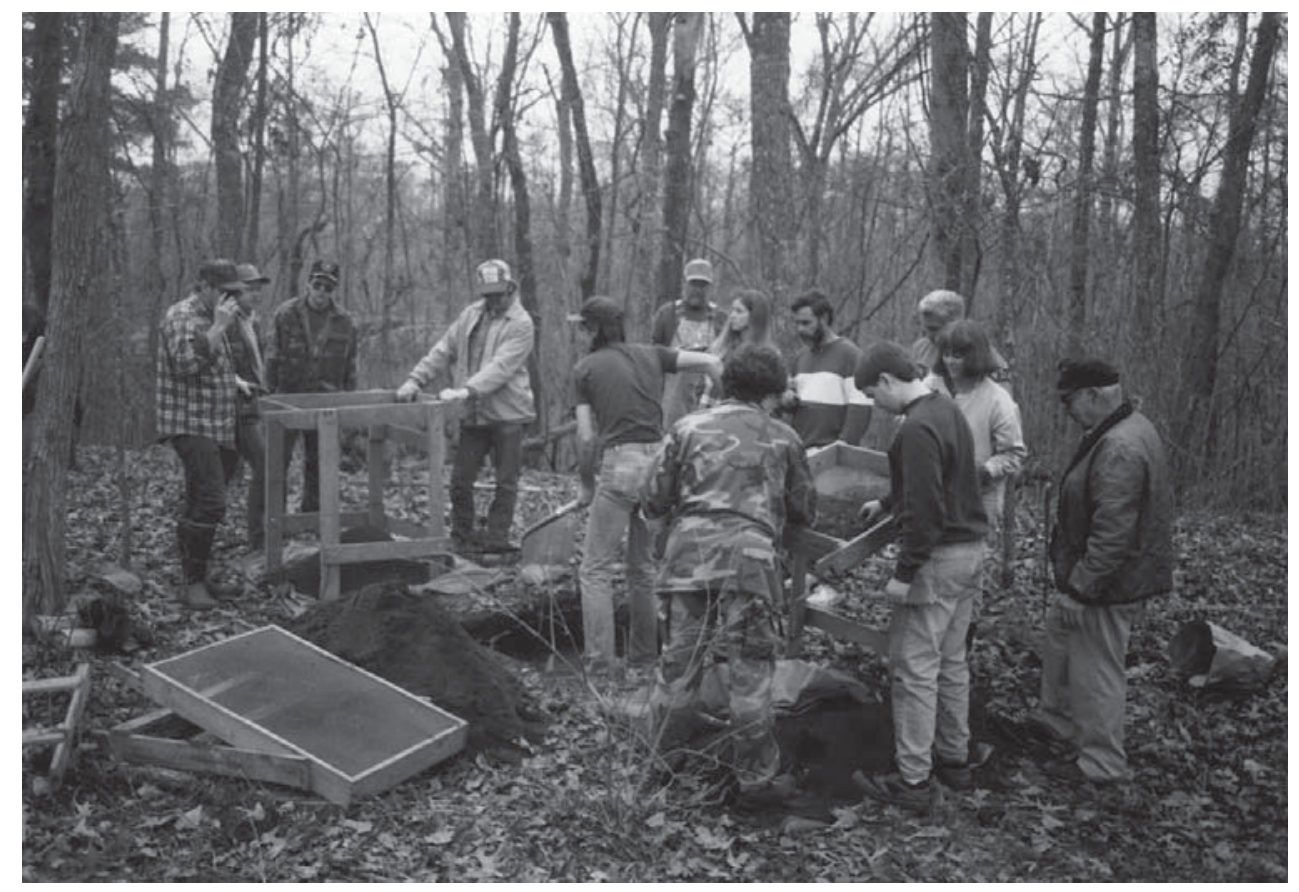

a

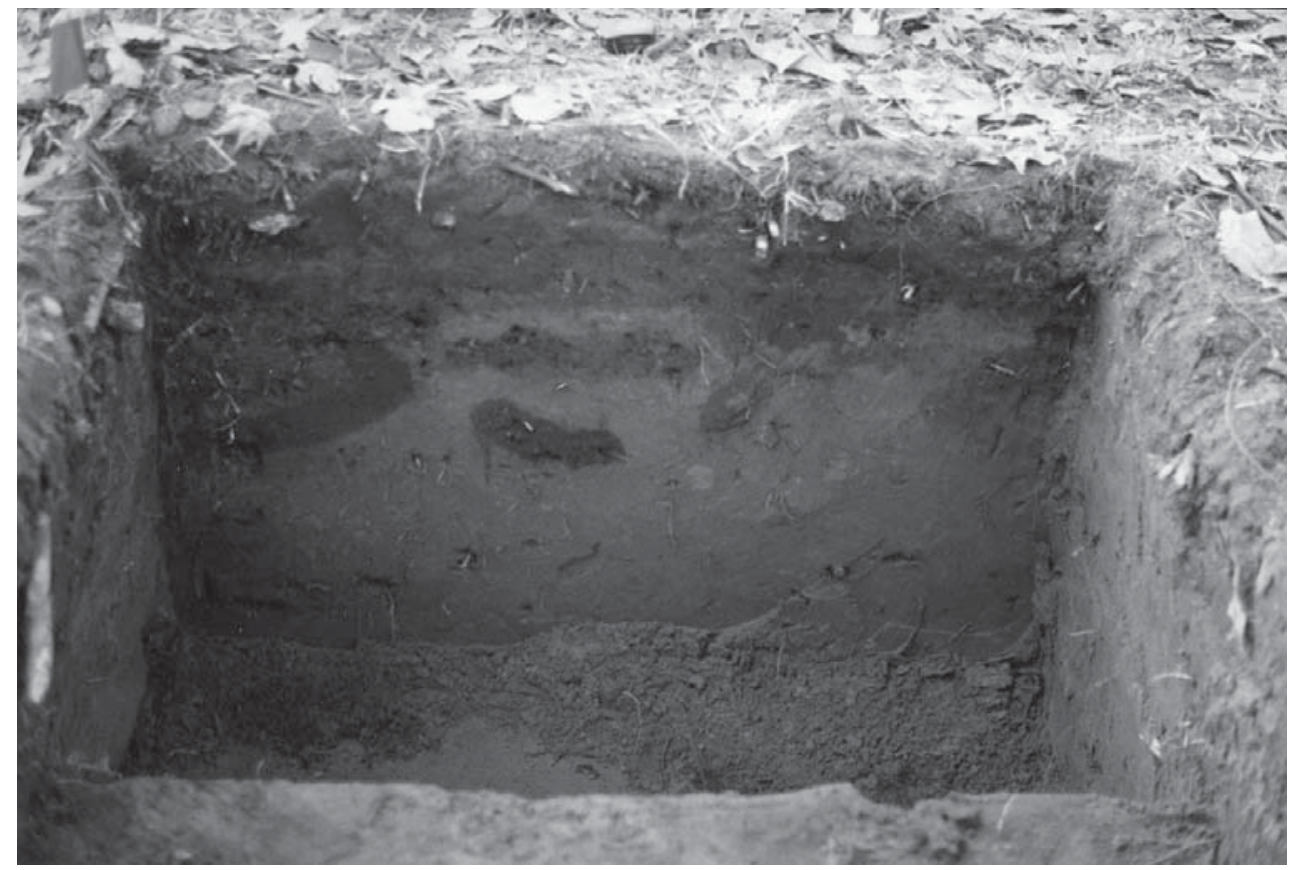

b

Figure 9. Unit 1 in Feature 2: a, excavations and screening of Unit 1; b, profile of Unit 1.

13d), wagon parts, and horse gear (Figure 14a-b). The majority of these metal artifacts were found in Feature 2 excavations.

Kitchen/domestic artifacts from the Monterey Lake site included refined earthenware and porcelain sherds from plates and cups $(n=925)$, several different kinds of stoneware $(n=76)$, much of this probably produced locally in stoneware kilns, bottle, snuff, and tableware glass sherds $(n=478)$, metal and silver-plated cutlery $(n=31)$ (Figure 15a-b), cast iron 


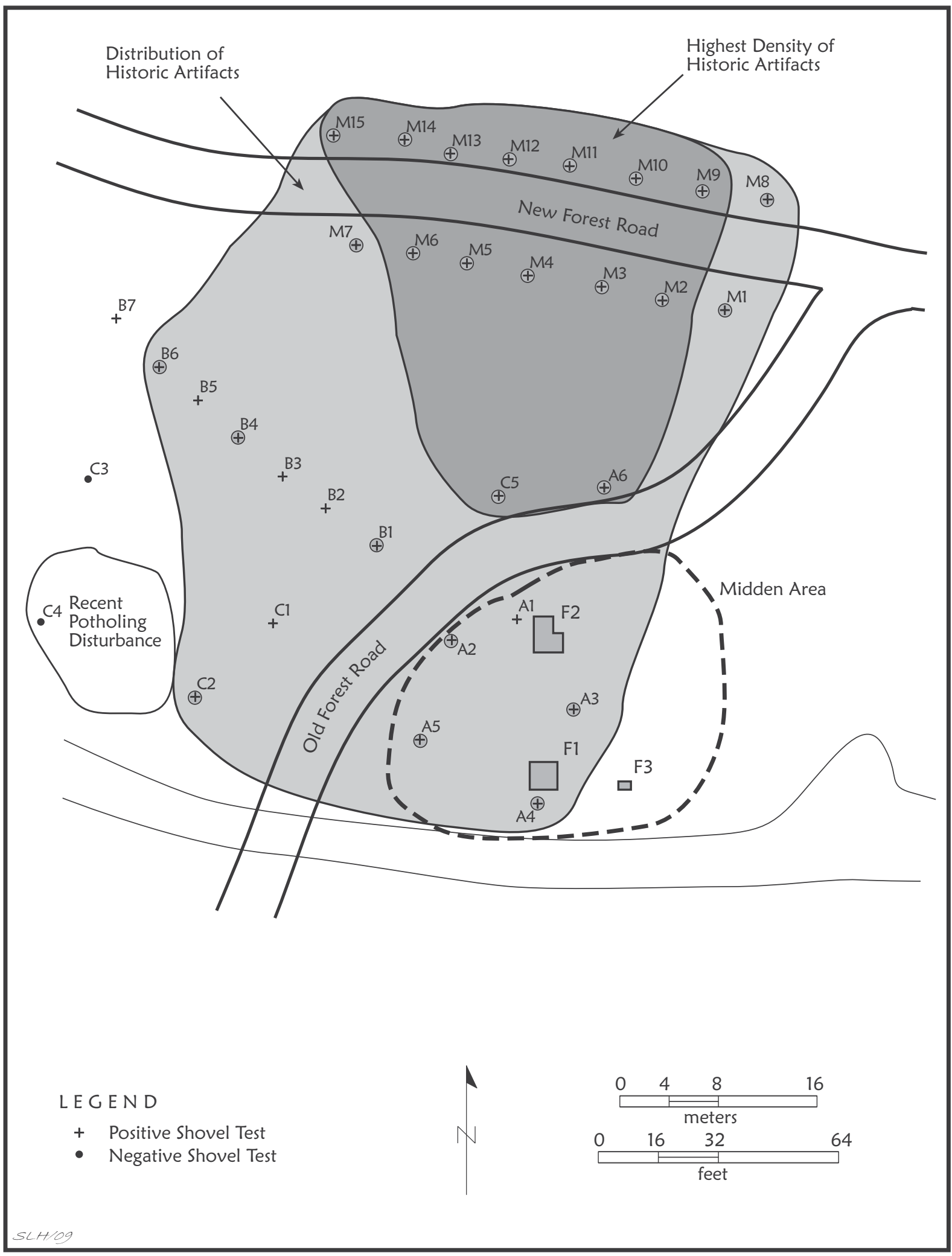

a

Figure 10. The distribution and density of artifacts from the shovel testing at the Monterey Lake site: a, $19^{\text {th }}$ century historic artifacts. 


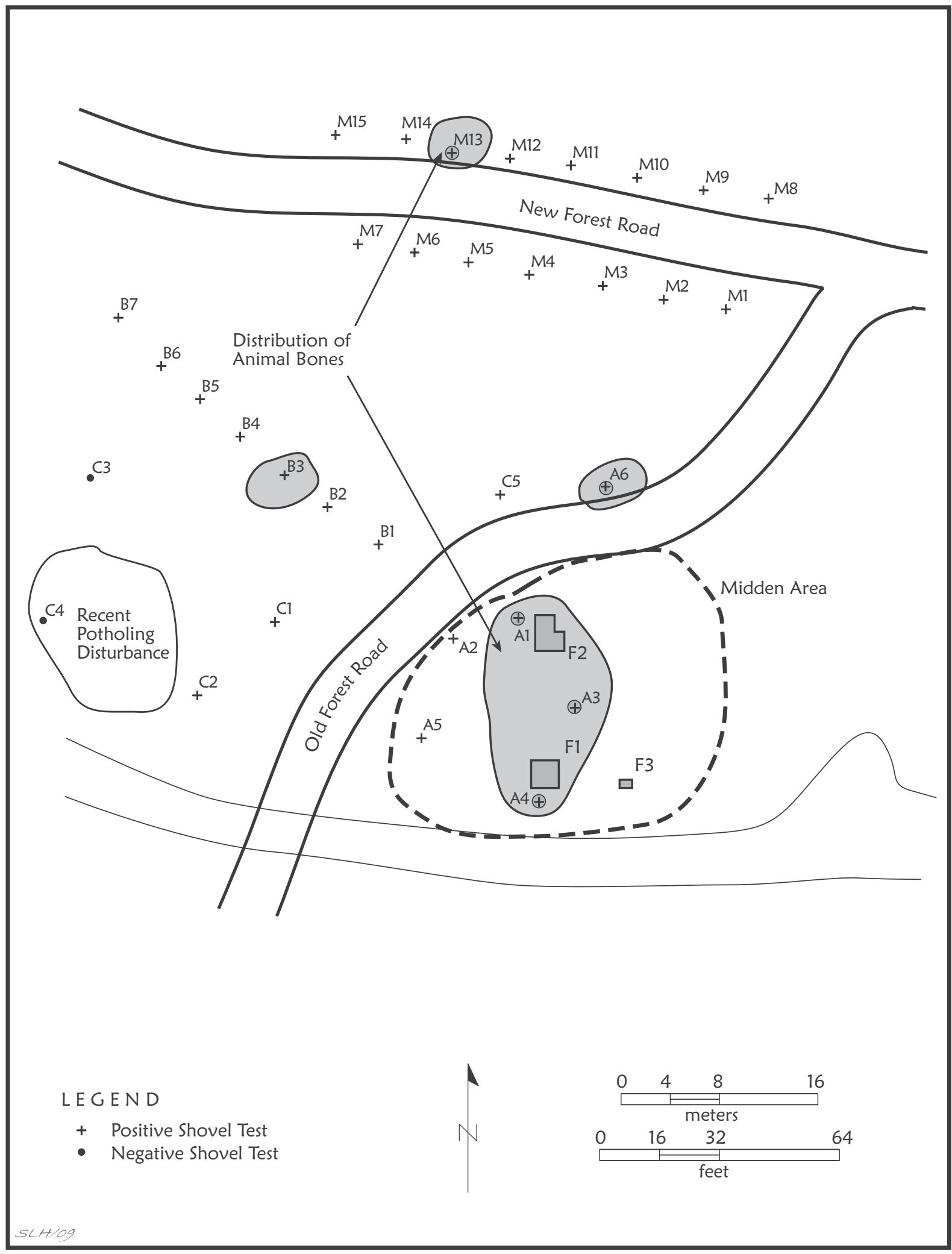

b

Figure 10. The distribution and density of artifacts from the shovel testing at the Monterey Lake site: b, faunal remains. 


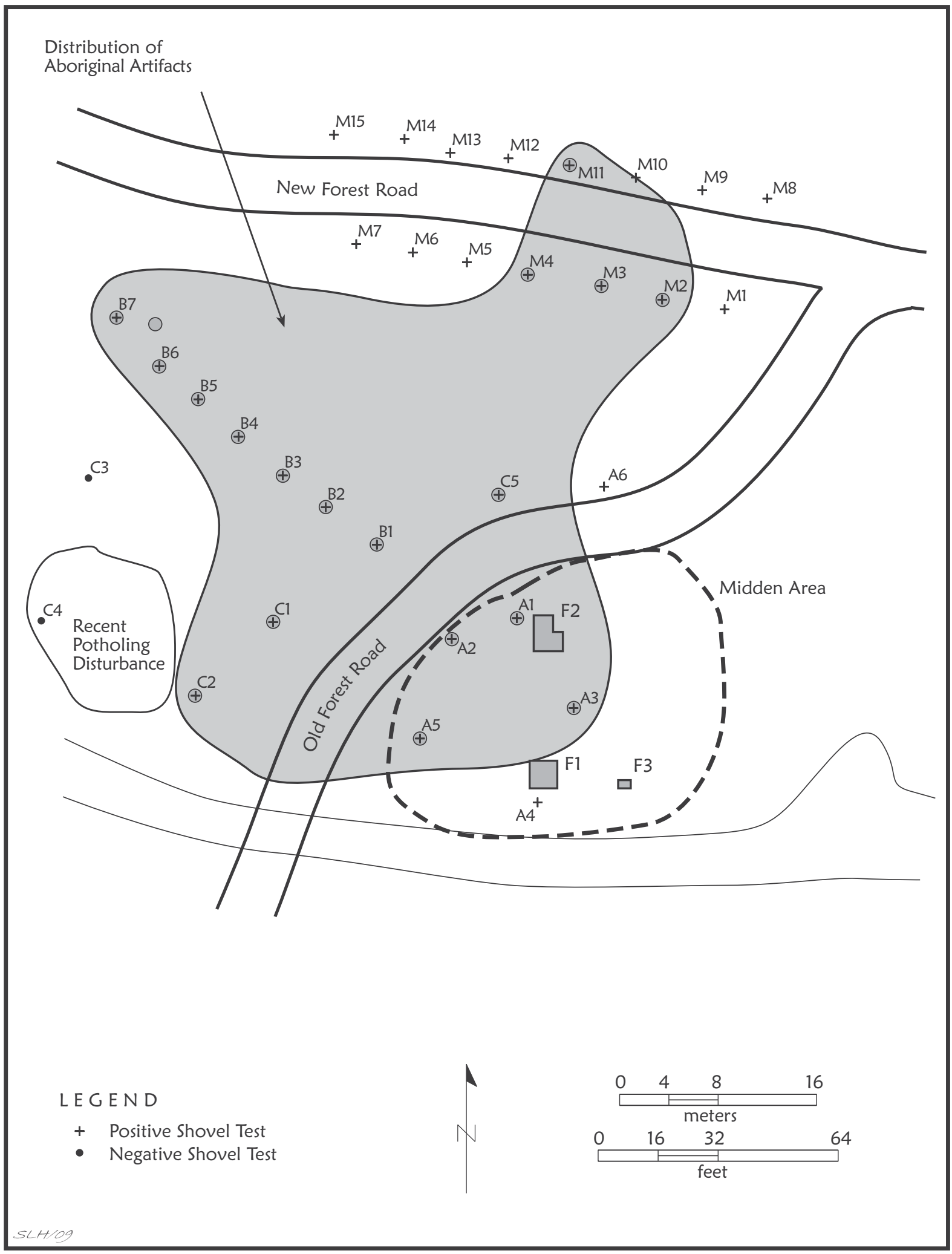

C

Figure 10. The distribution and density of artifacts from the shovel testing at the Monterey Lake site: c, aboriginal artifacts. 
Table 2. Structural/architectural artifacts.

\begin{tabular}{lcc}
\hline Artifact Description & No. & Comments \\
\hline cut nails & 841 & \\
hand-forged nail & 5 & \\
wire nails & 3 & \\
iron spikes & 10 & \\
& 52 & \\
hand-made brick fragments & 18 & thickness ranges from 1.8- \\
burned clay/daub & 11 & 2.5 mm \\
mortar/chinking & 29 & \\
window glass & & \\
& 969 & \\
\hline Total & & \\
\hline
\end{tabular}

Table 3. Tools, Horse, and Stable artifacts.

\begin{tabular}{lc}
\hline Artifact Description & No. \\
\hline iron chain link & 13 \\
iron spike-like item with barbed end & 1 \\
$\quad$ (fishhook) & \\
metal drill bit & 6 \\
iron disk & 1 \\
iron file & 2 \\
iron wedge & 1 \\
rolled piece of iron & 1 \\
iron axes & 2 \\
iron scissors & 3 \\
iron strips & 13 \\
iron knife handle & 5 \\
iron knife & 5 \\
bone-handled knife & 7 \\
pearl-handled jack knife & 1 \\
iron case knife & 5 \\
metal screw & 10 \\
metal gear & 1 \\
iron bar stock & 2 \\
iron nut & 1 \\
barrel opener & 1 \\
iron wagon parts & 92 \\
iron buckle or saddle girth & \\
iron bridle parts & 3 \\
iron stirrup & 2 \\
\hline Total & 5 \\
\hline
\end{tabular}




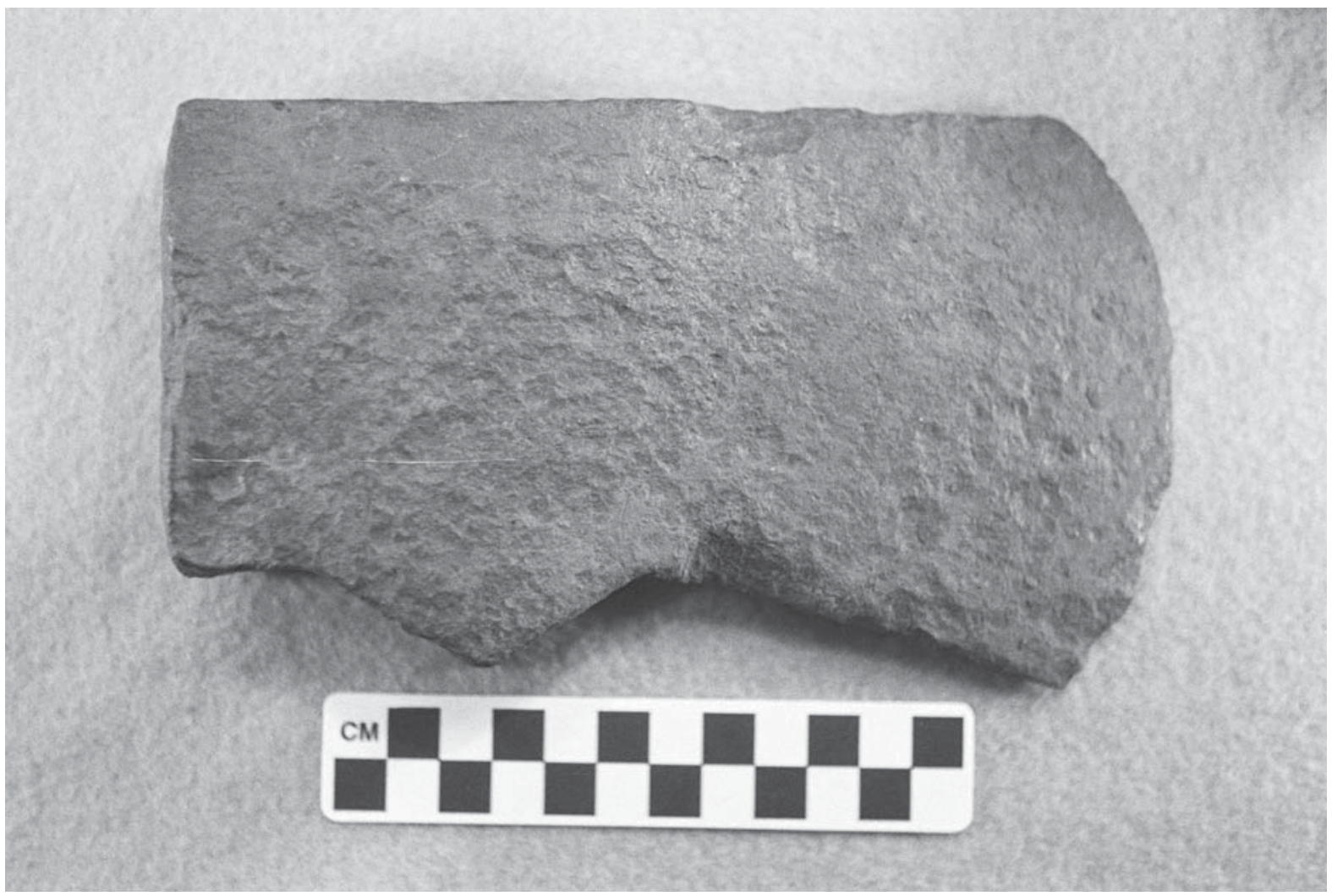

Figure 11. An iron axe from Feature 2 at the Monterey Lake site.

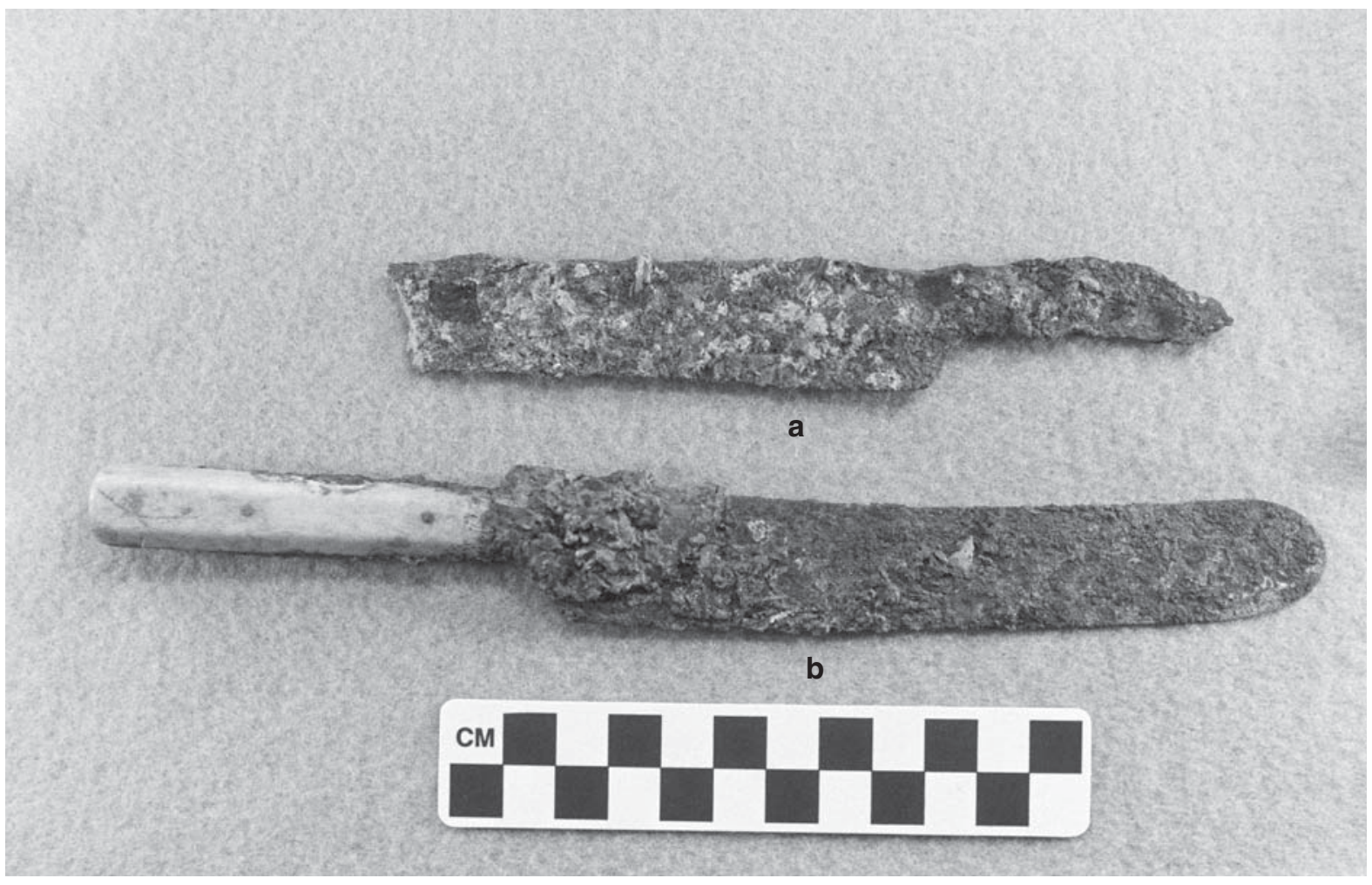

Figure 12. Knives from Unit 1 at the Monterey Lake site: $a$, iron case knife; b, bone-handled knife. 


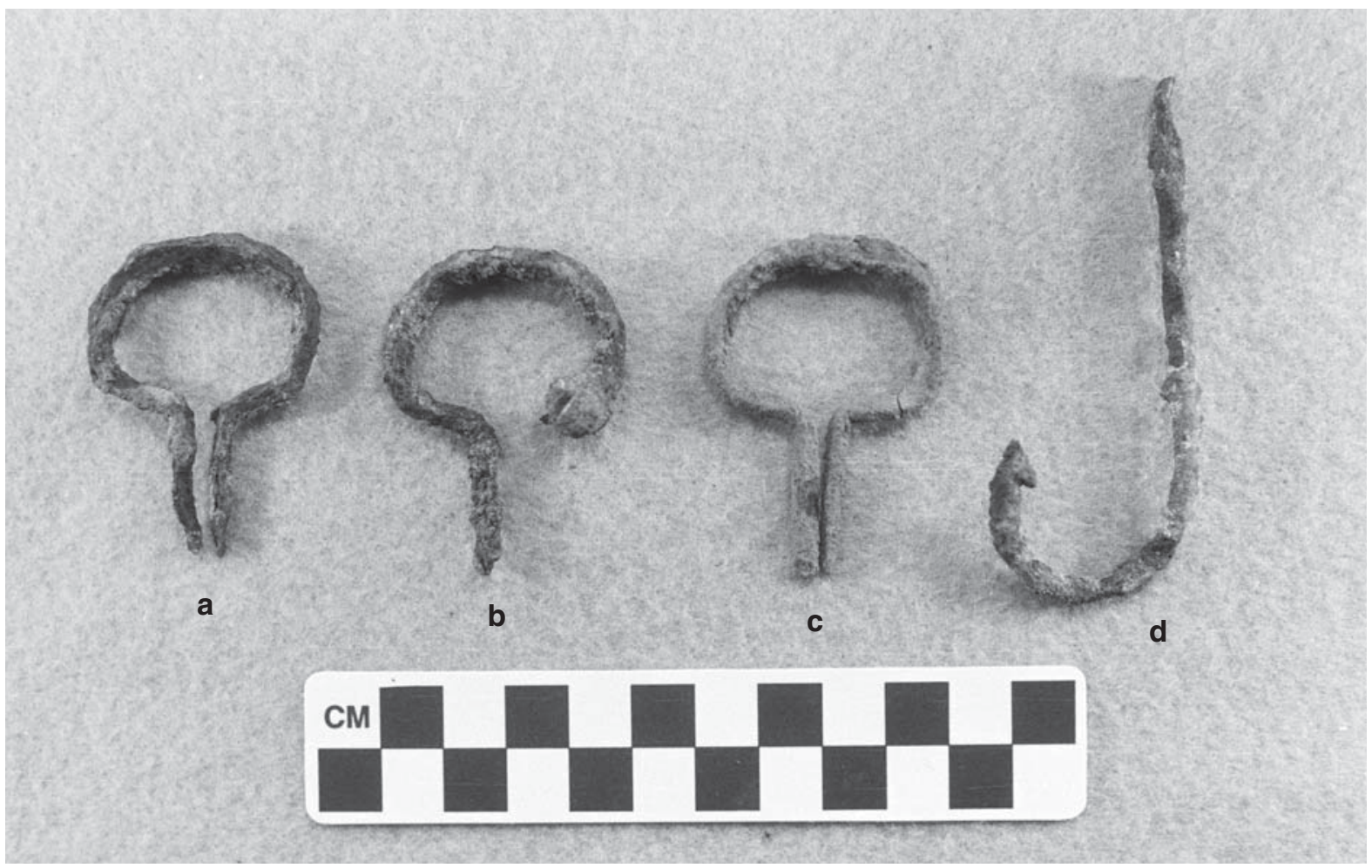

Figure 13. Jew's harps and a fish hook from Feature 2 at the Monterey Lake site: a-c, Jew's harps; d, fish hook.

kettle, pan, and stove parts $(n=7)$, and a few pieces of tin cans (Table 4). There are also two sherds from milk glass lid liners for glass fruit jars.

Randy Moir examined a large sample of the historic refined earthenware ceramic sherds from the Monterey Lake site as part of a workshop conducted during the 1999 Caddo Conference/East Texas Archeological Conference in Jefferson, Texas. His opinion was that the ceramic assemblage had:

paneled and molded white ironstone (some fairly early for that tradition) with cup and plate blanks of the late 1840 s and $1850 \mathrm{~s}$. I was amazed at the lack of decorated sherds/vessels which pushes much of the material after ca. 1845 and into the early 1850 s depending upon contexts and associations. There was a trace of pre 1845 material and one very elaborate vessel (tureen? platter?) that could be ca. 1835 to 1845 ...Last of all, there were several very nice porcelain/ soft paste porcelain vessels with enamel floral motifs of the ca. 1840 s to 1850 s period (molded in patterns just like the molded ironstones) (Randy Moir, March 15, 1999 e-mail communication).
Moir's inspection of the refined earthenware from the site is certainly corroborated by the decorated whiteware and porcelain sherds in the assemblage (Table 5). With the exception of a small amount of porcelain decalcomania dating from ca. 1880-1920 (Majewski and O'Brien 1987:147), and several ca. 1810-1835 blue shell-edged plate rims (Hunter and Miller 1994), the remainder of the decorated whiteware from the Monterey Lake site would seem to have been made and used between ca. 1830-1860 (cf. Price 1979; Majewski and O’Brien 1984, 1987). All of these decorated ceramic sherds are probably of English manufacture, and they likely were obtained through shipments of goods brought up the Red River and Caddo Lake to Jefferson and the small landing of Monterey.

The decorated whiteware from the site are dominated by transfer-prints of a variety of colors, especially blue and purple (Figure 16a-b), with floral, Chinese, and landscape motifs. The date ranges of production of the different colors of transfer-printed ceramics found at the site- blue (1784-1859); green (1818-1859); black (1785-1864); red (1818-1880); brown (1818-1869); and purple (1814-1867) (Samford 2000:Table 5) — and the fact that these transferprinted sherds are whitewares, would seem to indicate 


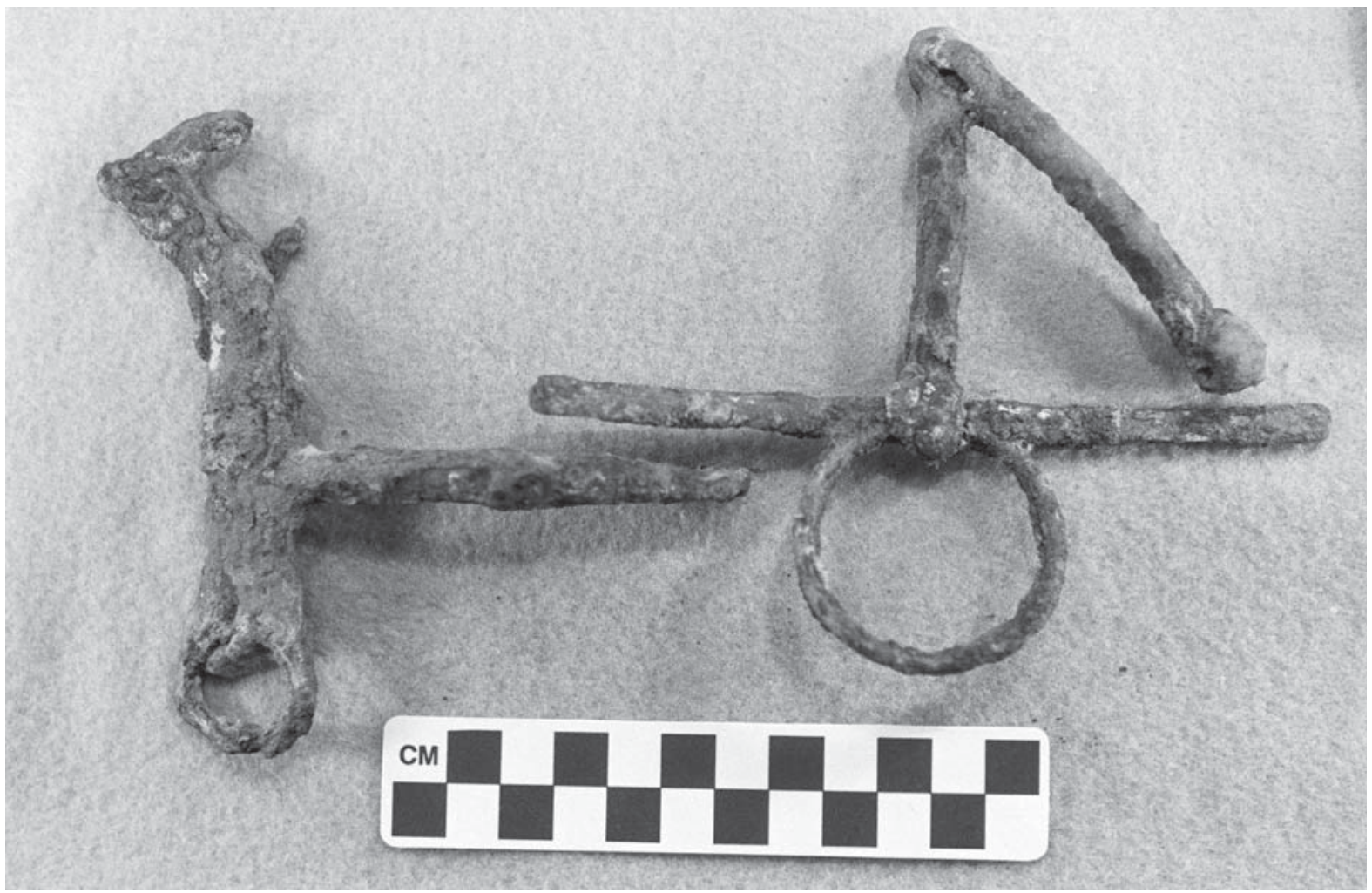

a

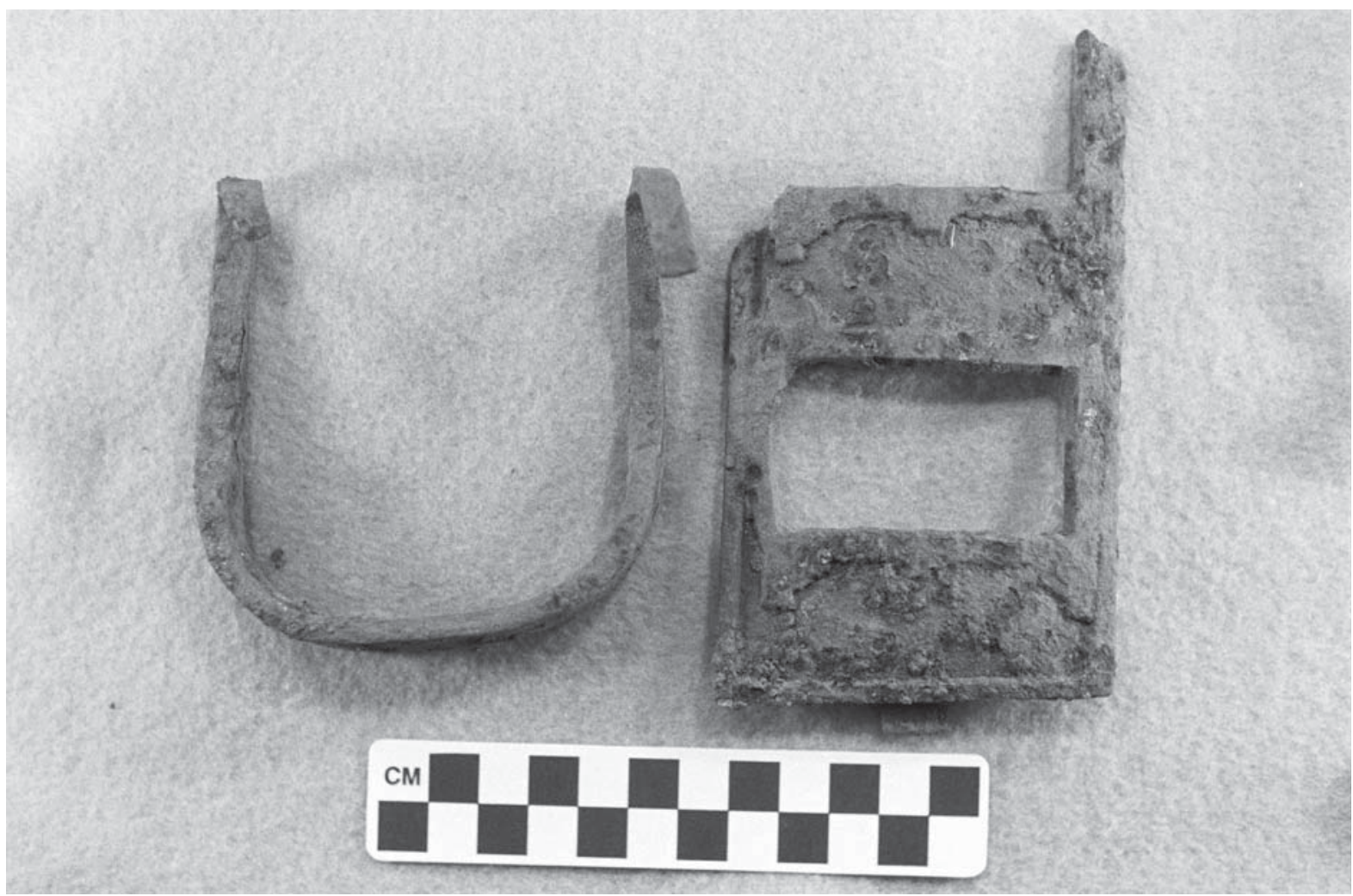

b

Figure 14. Horse gear from the Monterey Lake site: a, bridle parts, from Feature 1; b, horse gear from a miscellaneous context. 


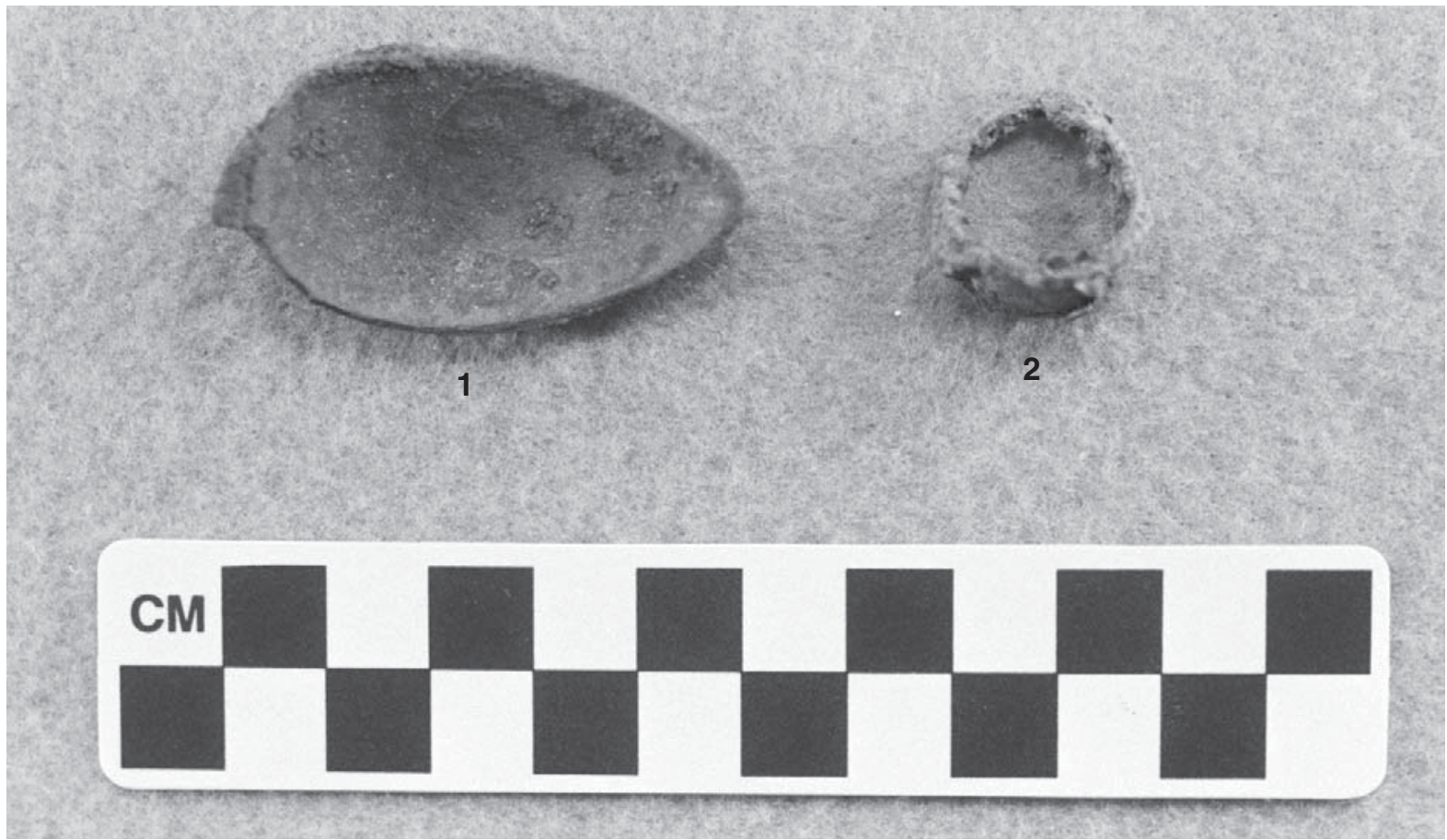

a

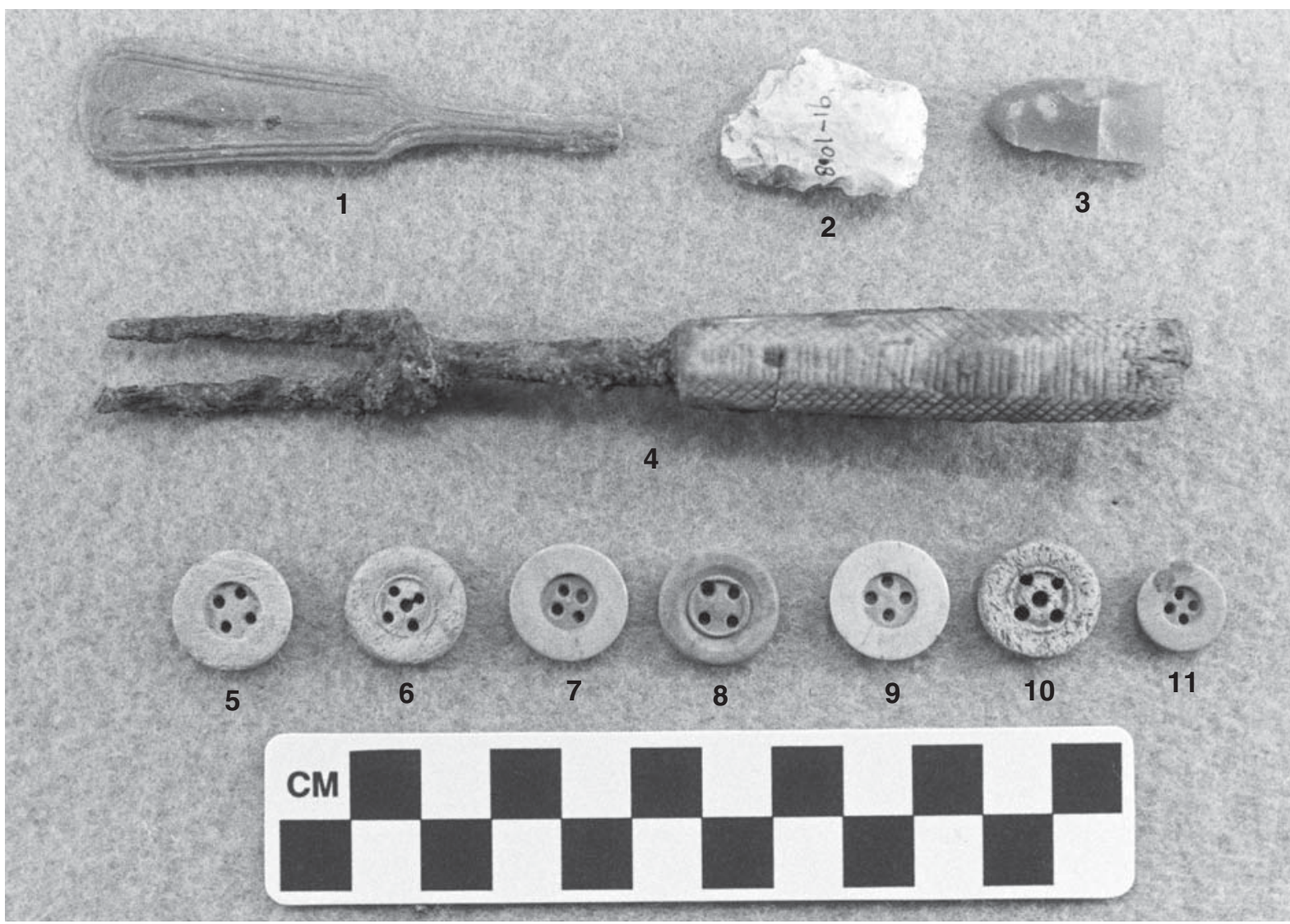

b

Figure 15. Kitchen cutlery, buttons, and gunflints from Unit 1/Feature 2 excavations at the Monterey Lake site: a, spoon (1), ring (2); b, spoon handle (1), gunflints (2-3), bone-handled fork (4), and bone buttons (5-11). 
Table 4. Kitchen/Domestic artifacts from the Monterey Lake Site (41MR77), Marion County, Texas.

\begin{tabular}{|c|c|c|}
\hline Artifact Description & No. & Comments \\
\hline decorated whiteware sherds & 349 & \\
\hline plain whiteware sherds & 515 & \\
\hline whiteware sherds with maker's marks & 11 & \\
\hline plain pearlware sherds & 1 & \\
\hline plain porcelain sherds & 29 & 1 is a sugar bowl lid \\
\hline decorated porcelain sherds & 12 & \\
\hline plain ironstone sherds & 8 & \\
\hline salt-glazed stoneware sherds & 24 & \\
\hline alkaline-glazed stoneware sherds & 25 & \\
\hline yellow ware sherds & 15 & \\
\hline lead-glazed stoneware sherds & 12 & \\
\hline bottle glass sherds & 435 & \\
\hline bottle stopper & 1 & \\
\hline snuff glass sherds & 4 & \\
\hline tableware glass sherds & 38 & \\
\hline milk glass sherds & 2 & \\
\hline metal spoon & 9 & $\begin{array}{l}1 \text { may have been worked into } \\
\text { a tool }\end{array}$ \\
\hline silver spoon & 19 & silver-plated \\
\hline metal two-tine fork & 3 & \\
\hline cast iron kettle sherds & 3 & \\
\hline cast iron pan sherds & 2 & \\
\hline cast iron stove parts & 2 & “...LPHIA" \\
\hline tin cans and fragments & 22 & \\
\hline Total & 1541 & \\
\hline
\end{tabular}

that the occupation at the Monterey Lake site could have ranged from ca. 1830-1867. Mean beginning and end production dates for the most common blue and purple transfer printed wares suggest that a number of these vessels were most likely manufactured between 1830-1843 (Samford 2000:Table 5), and then brought to the site after that time.

Several transfer-printed sherds from the site have hand-painted detail over the transfer-printed design (Figure 17c, e, h). Such decoration has been found in sites occupied between ca. 1840-1860 (Majewski and O'Brien 1987:143).
Annular wares (see Figure 17a, f) and flown blue sherds (see Figure 17b, d) comprise $14.8 \%$ of the decorated refined earthenware sherds from the site (see Table 5). The earthy tones of the annular wares from the Monterey Lake site-white, black, gray, and blue bands - suggest these sherds are from early (ca. 1840s) annular ware. Flown blue vessels became popular in the United States in the 1840s-1850s, especially those with landscape motifs (Samford 2000:79 and Table 7). Relief-molded sherds with panels and floral elements also became popular about 1840 (Majewski and O’Brien 1987:153). 
Table 5. Decorated whiteware and porcelain sherds from the Monterey Lake site (41MR77).

\begin{tabular}{|c|c|}
\hline Decoration & $\%$ \\
\hline hand-painted, floral, whiteware & 20.4 \\
\hline blue shell-edged, unscalloped rim and impressed lines & 6.8 \\
\hline blue shell-edged, unscalloped rim and painted lines & 0.6 \\
\hline green shell-edged, unscalloped rim and impressed lines & 1.5 \\
\hline blue shell-edged, even scalloped rim and impressed lines & 0.6 \\
\hline subtotal & 9.5 \\
\hline relief-molded, panels and floral & 3.0 \\
\hline purple transfer-printed & 7.1 \\
\hline green transfer-printed & 1.8 \\
\hline black transfer-printed & 0.6 \\
\hline red transfer-printed & 4.4 \\
\hline blue transfer-printed & 28.7 \\
\hline brown transfer-printed & 3.0 \\
\hline subtotal & 45.6 \\
\hline hand-painted over transfer-printed & 1.5 \\
\hline white-black-blue annular ware & 2.3 \\
\hline white-black-blue-gray annular ware & 5.6 \\
\hline blue-white annular ware & 2.7 \\
\hline blue-white-gray annular ware & 0.3 \\
\hline blue annular ware & 0.3 \\
\hline gray annular ware & 0.3 \\
\hline subtotal & 11.5 \\
\hline flown blue sherds & 3.3 \\
\hline sponge/spatter ware sherds & 1.8 \\
\hline hand-painted band, porcelain & 2.1 \\
\hline porcelain decalcomania & 1.5 \\
\hline
\end{tabular}

The hand-painted sherds from the site primarily have polychrome floral motifs, but a number of rim sherds have blue or red hand-painted rim bands (Figure 18a). Approximately $9.5 \%$ of the decorated whiteware are from blue or green shelledged plates (Figure 18b; see Table 5). About 84\% of the shell-edged plates are blue in color; green shell-edged plates began to diminish in frequency after 1800 relative to blue shell-edged plates
(Sussman 2000:51). With respect to the rim form of the Monterey Lake shell-edged ceramics, which is chronologically sensitive (cf. Hunter and Miller 1994), $87 \%$ have unscalloped rims and impressed lines (ca. 1830-1860); 7\% are from ca. 1860-1890 blue shell-edged plates that have unscalloped rims and painted, not impressed, lines and 6\% are from plates with even scalloped (ca. 1810-1835) and impressed lines. 


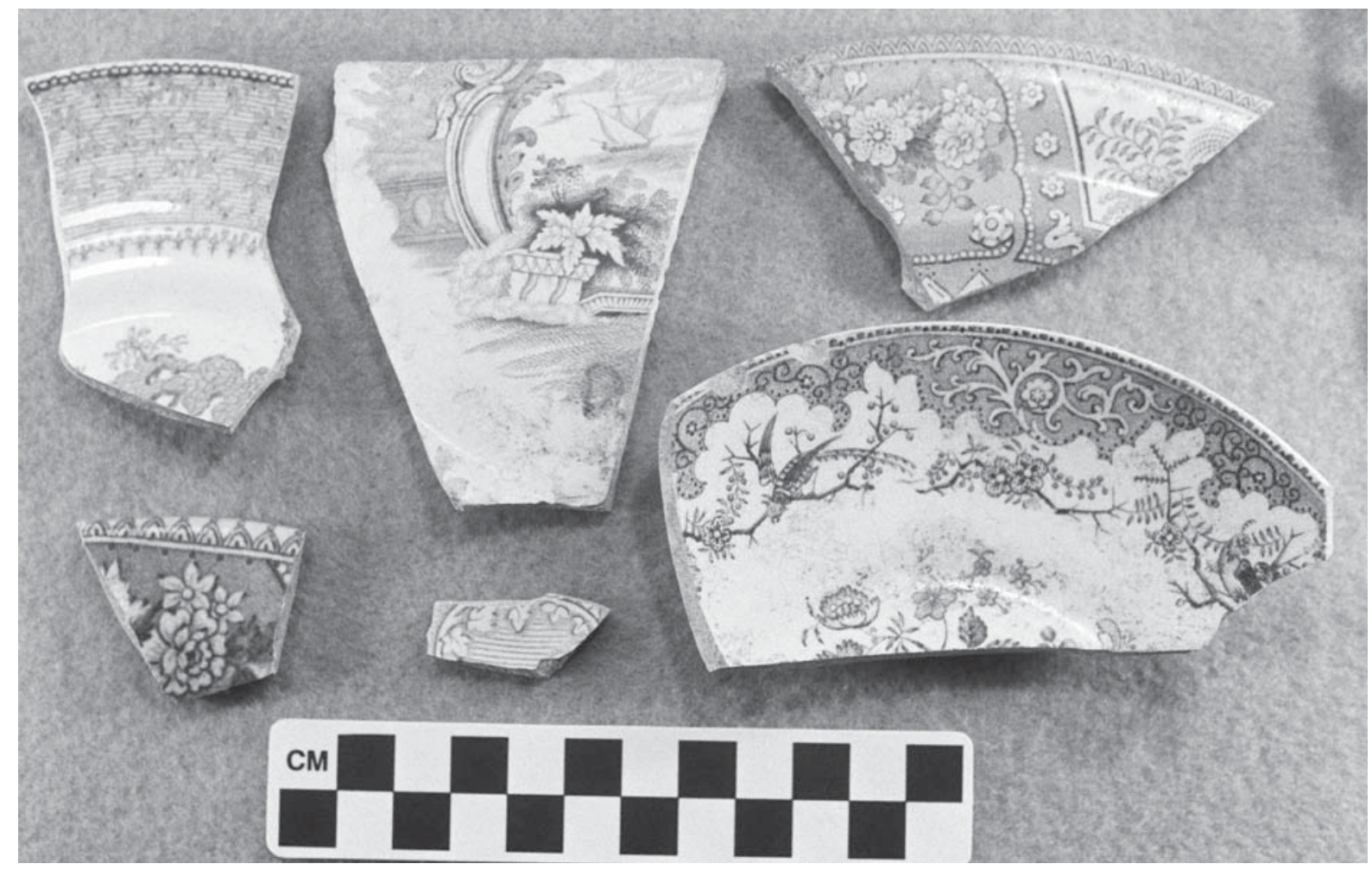

a

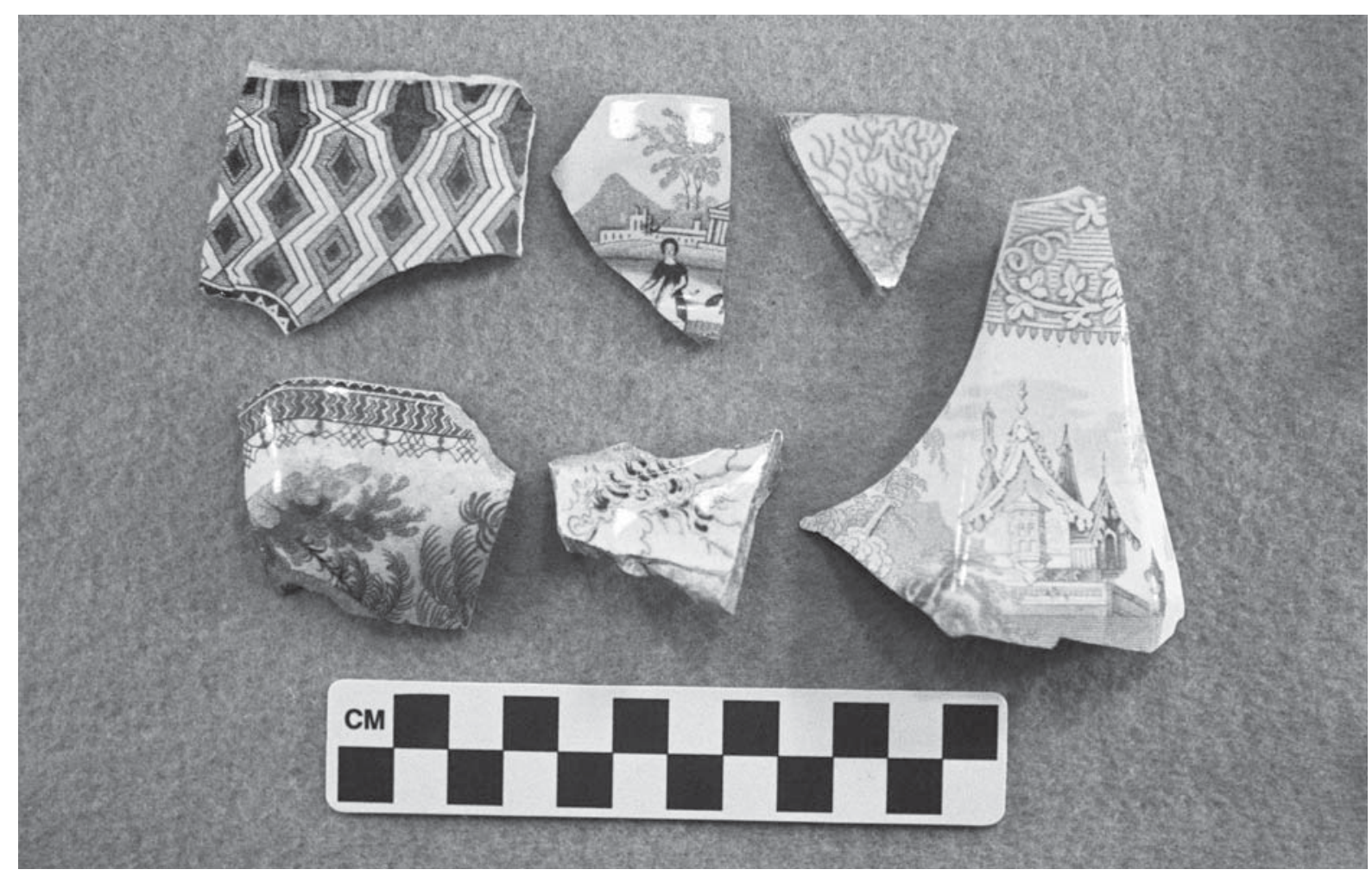

b

Figure 16. Transfer-printed sherds from the Monterey Lake site: a, blue, red, green, and purple transfer-printed sherds from Feature 2; b, blue and brown transfer-printed sherds from various contexts at the Monterey Lake site. 


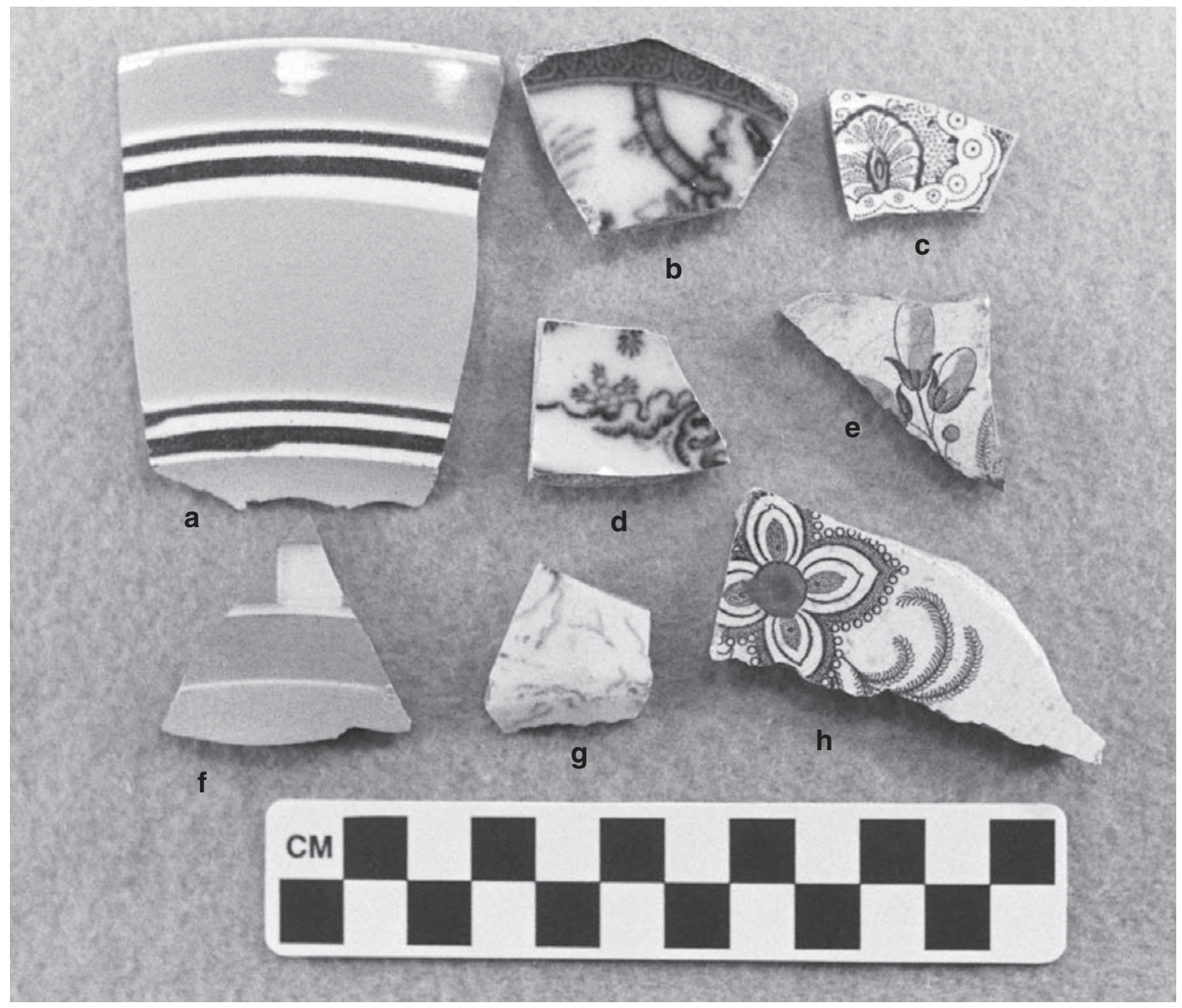

Figure 17. Annular, flown blue, hand-painted over transfer-printed, and sponge/spatter ware sherds from the Monterey Lake site: a, f, annular ware; b, d, flown blue; c, e, h, hand-painted over transfer-printed; g, sponge/spatter.

A number of whiteware sherds from the Monterey Lake site have impressed or stamped maker's marks. Six of them have impressed Davenport date marks - an anchor with the years of manufacture (i.e., 4/4 for 1844) (Godden 1963; Miller 1998) on either side of the anchor-that range from 1844 to 1848 ; most of the dates are concentrated on the year 1848. These occur on plain whiteware flatware $(n=4)$ and hand-painted (broad-lined polychrome) hollowware whiteware. The only other maker's marks in the assemblage are a British registration mark on a vessel of September 8, 1848, and a post-1837 Royal Arms mark on "Stone China" (Godden 1964:552). A transfer-printed plate from the site has an unascribed Scenic 1 pattern (Pollan et al. 1996:79), estimated to date from ca. 1828-1880. These established dates on the ceramics, as well as the estimated dates on the decorated whiteware discussed above, are consistent with the known occupation of Monterey, a steam boat stop along Caddo Lake (see Bagur 2001). The community was known from historic records to have been settled by 1848 , but had only 30 people living there by 1884 .

The stoneware sherds found in the archaeological deposits at the Monterey Lake site include salt-glazed $(n=24)$, alkaline-glazed $(n=25)$, lead-glazed $(n=10)$, and yellow ware ( $\mathrm{n}=15$ (see Table 5) (Figure 19). These particular kinds of stoneware would have been manufactured and used between the 1830s and ca. 1875. Salt glazing was one of the more commonly employed glazes in the manufacture of utilitarian stoneware (Greer 1981:180). The absence of saltglazed stoneware sherds with a natural clay slipped interior surface suggests that these particular stoneware vessels were made before ca. 1870 (Lebo 1987:140).

Alkaline-glazed stoneware was relatively cheap to manufacture compared to salt-glazed stoneware because the ingredients (ash, clay, and sand) were locally 


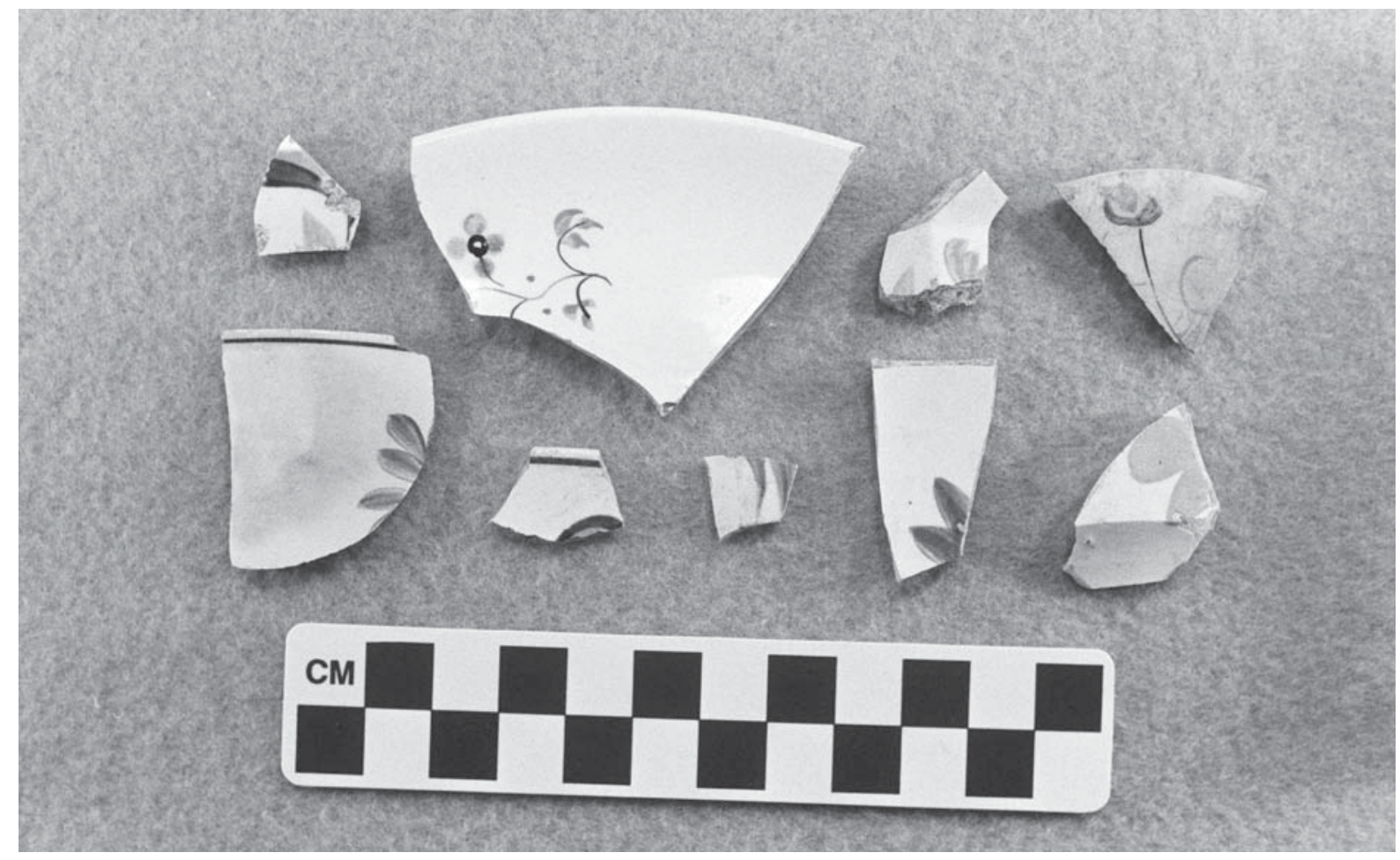

a

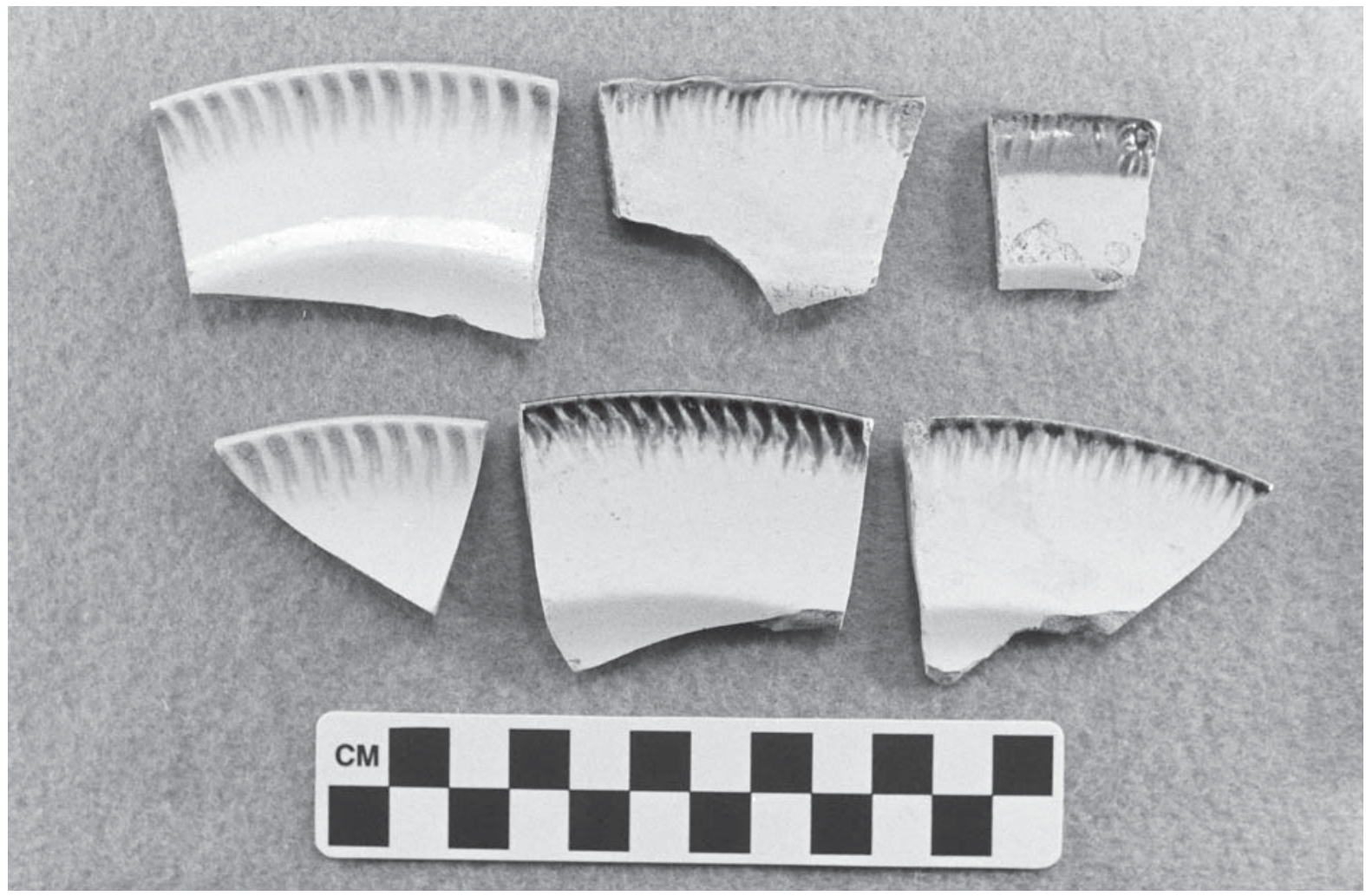

b

Figure 18. Hand-painted and shell-edged whiteware sherds from Feature 2 at the Monterey Lake site: a, hand-painted rim and body sherds; $b$, blue and green shell-edged rims. 


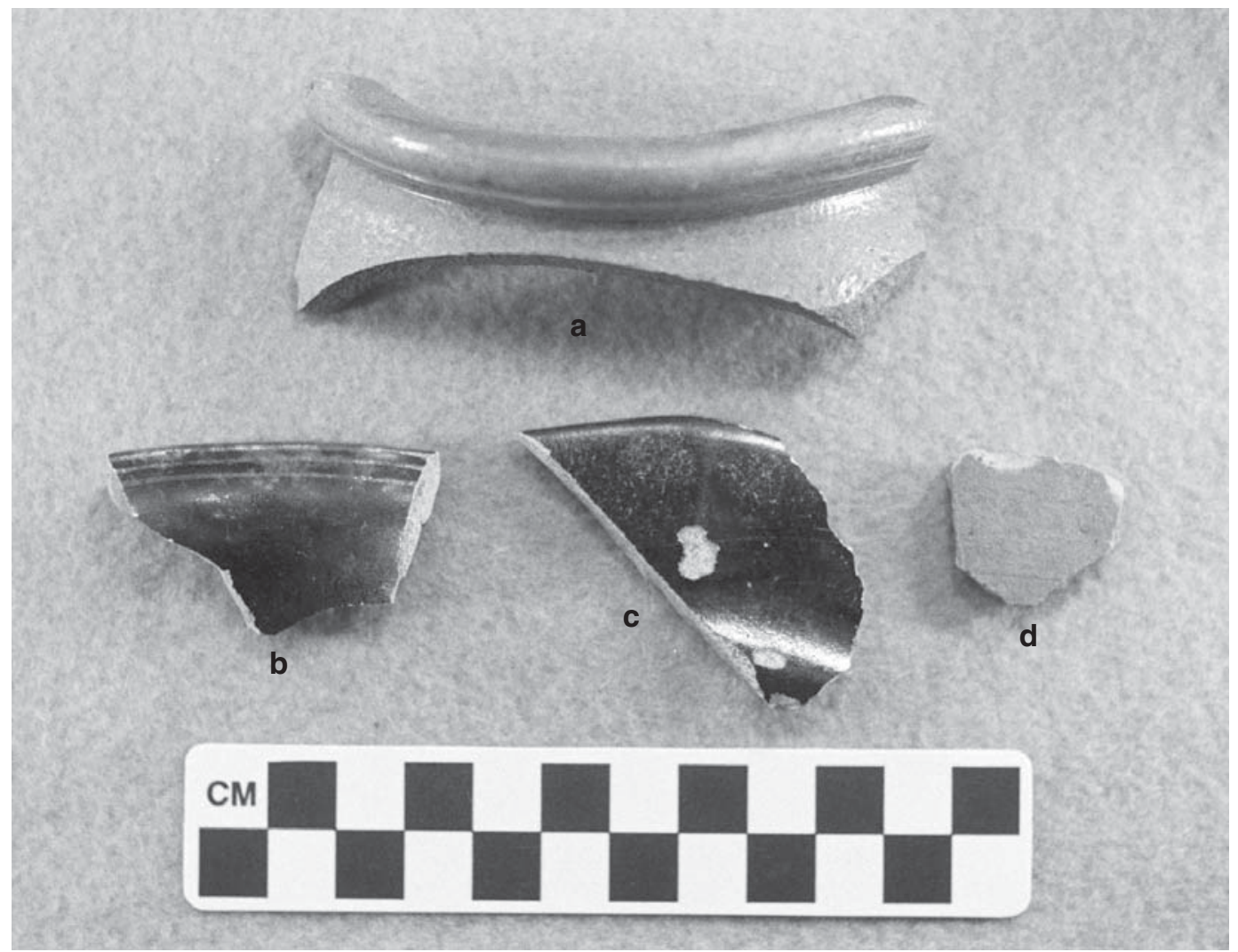

Figure 19. Stoneware from Feature 2: a, salt-glazed; b-c, lead-glazed; d, yellowware.

and readily available. The use of the alkaline glaze was particularly popular in rural settings in the southern United States in the $19^{\text {th }}$ century (Burrison 1975). Alkaline-glazed pottery began to be manufactured in Texas in about 1839, and remained a popular stoneware until ca. 1875 (Lebo 1987:141). Alkaline-glazed stonewares were produced at a number of potteries in northeastern Texas, including several in Marion County (Lebo 1987:Table 8-1). A likely source for the alkaline-glazed stoneware at the Monterey Lake site would have been one of the potteries in Jefferson, such as the J. S. Nash pottery (41MR57), since it was the major and nearby commercial center in the region up to the 1870s (Bagur 2001).

The lead-glazed stonewares have a brown lead glaze on both interior and exterior surfaces (see Figure $19 \mathrm{~b}-\mathrm{c}$ ). This was a popular stoneware made and used between ca. 1870-1900, after which this form of stoneware greatly declined in popularity.

Yellowware began to be produced in the 1820 s in England, but by the 1840s it was also being manufactured in the United States, especially in the Midwest (Leibowitz 1985:4). The peak production of yellowware vessels was in the 1860s and 1870s, although it was still being made in the early $1900 \mathrm{~s}$ (Leibowitz 1985:14).

The bottle glass from the Monterey Lake site are from hand-blown bottles of several different colors, principally aqua, colorless, and olive green (Table 6). They have applied lips (Figure 20a) and iron-tipped pontil marks (cf. Jones 2000:158-159) on their base, marking a method of holding the bottle during the finishing process that was used from the early $19^{\text {th }}$ century until the 1870 s. These vessels or containers include small medicinal vials with handapplied lips (Figure 20b), liquor (beer and wine), case, and aqua, colorless, olive green, and purple paneled bottles.

Several of the aqua, colorless, olive green, and purple (1880-World War I manufacture) paneled bottle sherds have embossed lettering, a technique which began to be used about 1850 (Newman 1970:74). These paneled bottles likely contained medicines, either with patented (which were made between ca. 1867-1915) or unpatented mixtures of alcohol, herbs, cocaine, and opium (Torbenson et al. 2000).

The olive green to dark olive green bottle glass are probably from mid- $19^{\text {th }}$ century bottles that 
Table 6. Kinds of bottle glass found at the Monterey Lake site.

\begin{tabular}{|c|c|c|}
\hline Bottle glass description & $\%$ & Comments \\
\hline aqua bottle sherd & 43.2 & $\begin{array}{l}\text { pontil base; embossed } \\
\text { lettering; vials }\end{array}$ \\
\hline colorless bottle sherd & 33.0 & $\begin{array}{l}1 \text { stopper; pontil bases } \\
\text { embossed lettering }\end{array}$ \\
\hline olive green bottle sherd & 13.6 & $\begin{array}{l}\text { pontil base; embossed } \\
\text { lettering }\end{array}$ \\
\hline dark green bottle sherd & 4.1 & pontil base; Troy, NY \\
\hline amber bottle sherd & 2.5 & snuff bottles \\
\hline brown bottle sherd & 2.5 & includes snuff bottles \\
\hline purple bottle sherd & 0.9 & $\begin{array}{l}\text { paneled; embossed } \\
\text { lettering }\end{array}$ \\
\hline blue bottle sherd & 0.2 & flask \\
\hline Total & 440 & \\
\hline
\end{tabular}

contained wine, whiskey, or brandy. The amber glass and some of the brown bottle glass are from the body of a case container, probably a rectangular snuff bottle. Similar four-sided snuff containers ${ }^{1}$ with short necks and beveled shoulders have been found at the 1852-1857 James Frank site (41DT97) and the 1837-1846 Milligan Point site (41CP276) in northeastern Texas (Perttula 1989:90; Nelson and Perttula 2003:32). The remainder of the brown glass is likely from beer bottles or small case containers.

One sherd is from a light blue glass flask with a molded surface decoration (Figure 20b:6). According to Parsons et al. (2002:57-58), these flasks were 'made mostly between 1825-1852, [and] were decorated with depictions of famous statesmen or historical events."

There is a wide assortment of clothing/ adornment items and personal use artifacts in the Monterey Lake site assemblage (Table 7). These include several different kinds of buttons $(n=62)$ (Figure 21a), beads, a small silver ornament, and metal pins (Figure 21b), kaolin and stoneware pipe sherds (Figure 22), stone and clay marbles ( $n=13)$, a bone lice comb (Figure 23a), a reading glass frame (Figure 23f), brass cylinders, a copper thimble, mirror glass sherds, Jew's harps (see Figure 13a-c), and a pre-1900 graphite core for a pencil (Figure 23d).

The clothing buttons are 2-4 holed mussel shell, 3-4-holed porcelain (popular between 1850-1910, Meissner 1997a:120), and 4-5-holed bone buttons, as well as 4-holed iron and brass buttons (see
Figure 21a). The mussel shell buttons appear to be hand-cut; by ca. 1850, mussel shell buttons were machine cut (Meissner 1997a). It is possible that the shell buttons were made from mussel shells gathered from the Mississippi River (Claassen 1994), although it is possible that they were made from Caddo Lake mussels, though the full-scale shell button industry at Caddo Lake was not in operation until the early years of the $20^{\text {th }}$ century (Shira 1913; Dahmer 1995:40). Bone buttons, possibly used for jackets, coats, or vests, were produced in quantities in the United States up to ca. 1860 (Castille et al. 1982:5-109).

Toys found at the Monterey Lake site include stone and clay marbles as well as ca. mid-19 century to World War I-era porcelain china doll plate sherd (Meissner 1997b). Stone marbles were manufactured in Europe and North America from ca. 1700-1927, but with several peaks in production over that time, including one in the mid- $19^{\text {th }}$ century (Zapata 1997:104). Clay marbles began to be produced around 1840 .

The beads from the site, both from Feature 2 (see Figure 21b), include single examples of faceted and donut-shaped or hollow cane forms. Similar beads have been found in ca. 1800-late 1830s contexts at 41MR211 (Timber Hill) (Parsons et al. 2002), an historic Caddo site at Caddo Lake, as well as an 1837-1846 Anglo-American site on Big Cypress Creek (Nelson and Perttula 2003:33), and an 1852-1857 Anglo-American farm on the South 


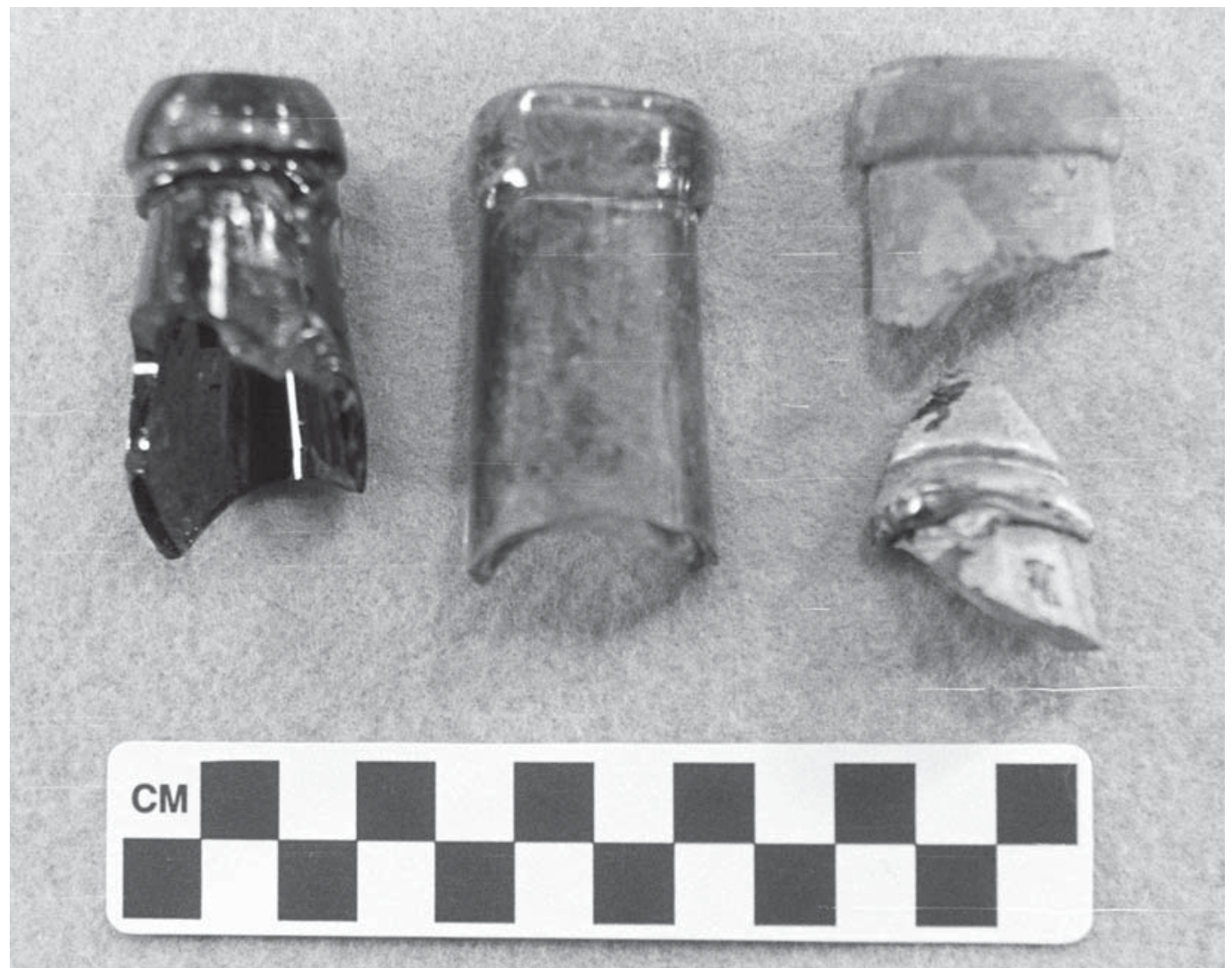

a

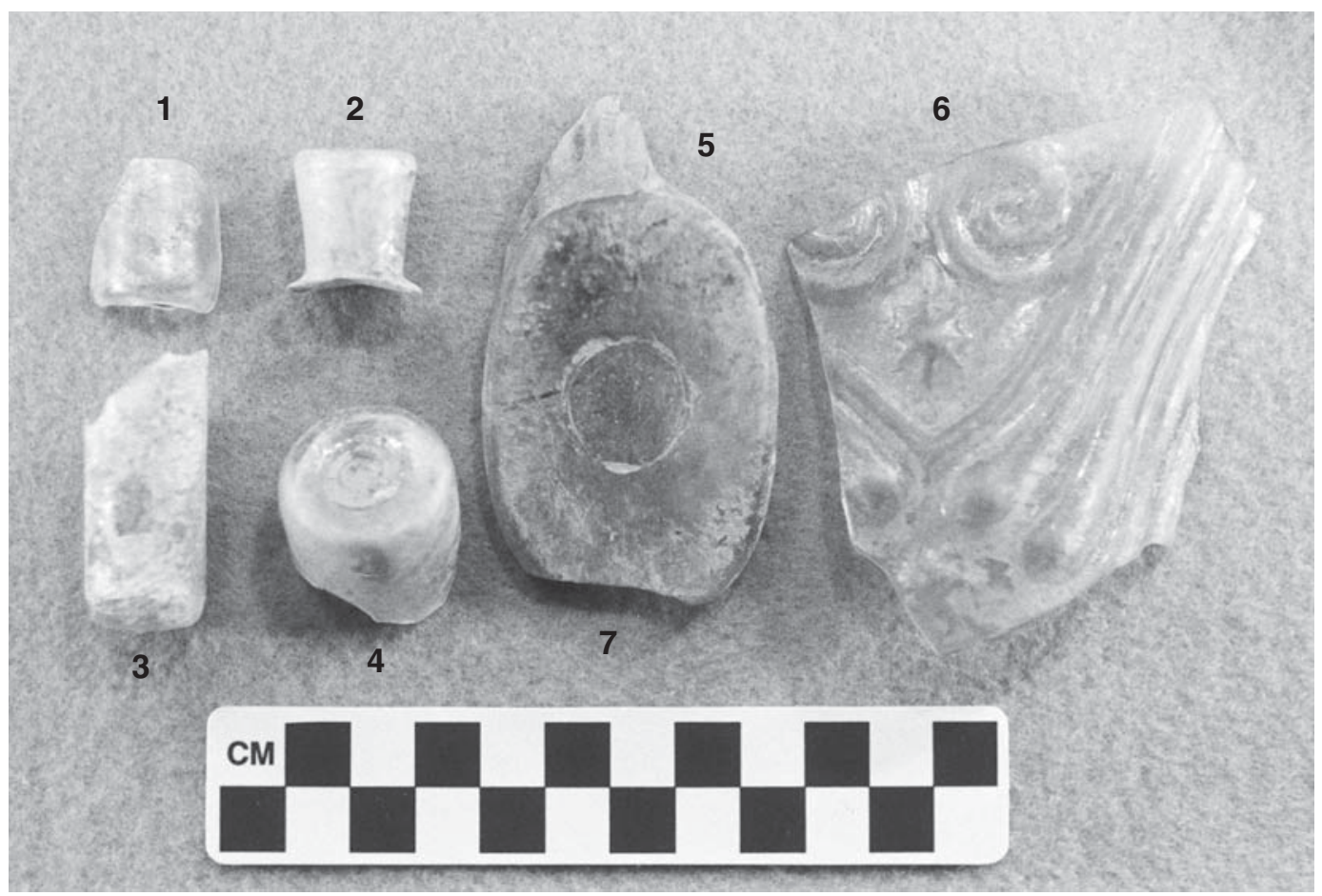

b

Figure 20. Bottle sherds from the Monterey Lake site: a, hand-blown bottle lips from Feature 2; b, aquacolored vials (1-4), bottle base with a pontil mark (5), and flask (6). 
Table 7. Clothing/Adornment and Personal use artifacts.

\begin{tabular}{|c|c|c|}
\hline Artifact Description & No. & Comments \\
\hline kaolin pipe sherds & 8 & \\
\hline stoneware pipe sherds & 7 & \\
\hline bone button & 30 & \\
\hline shell button & 14 & \\
\hline porcelain button & 5 & \\
\hline iron button & 9 & 1 is an overall button \\
\hline brass buttons & 4 & \\
\hline stone marble & 11 & \\
\hline clay marbles & 2 & \\
\hline glass beads & 2 & \\
\hline cupreous ring & 1 & \\
\hline brass clothing clasp & 2 & 1 with floral impressions \\
\hline brass pins & 3 & \\
\hline metal pin and clasp & 1 & \\
\hline metal pin & 1 & \\
\hline wire pin with hole thread & 1 & \\
\hline suspender clasp & 1 & \\
\hline shoe heel, with nails & 1 & \\
\hline brass reading glass frame & 1 & \\
\hline copper thimble & 1 & \\
\hline metal buckles & 7 & \\
\hline cut brass strips and ovals & 6 & \\
\hline brass cylinders & 2 & \\
\hline bone lice comb & 1 & \\
\hline Jew's harps & 3 & \\
\hline silver ornament & 1 & \\
\hline graphite core for pencil & 1 & \\
\hline slate & 2 & \\
\hline china doll toy plate sherd & 1 & \\
\hline mirror glass sherds & 38 & \\
\hline Total & 167 & \\
\hline
\end{tabular}




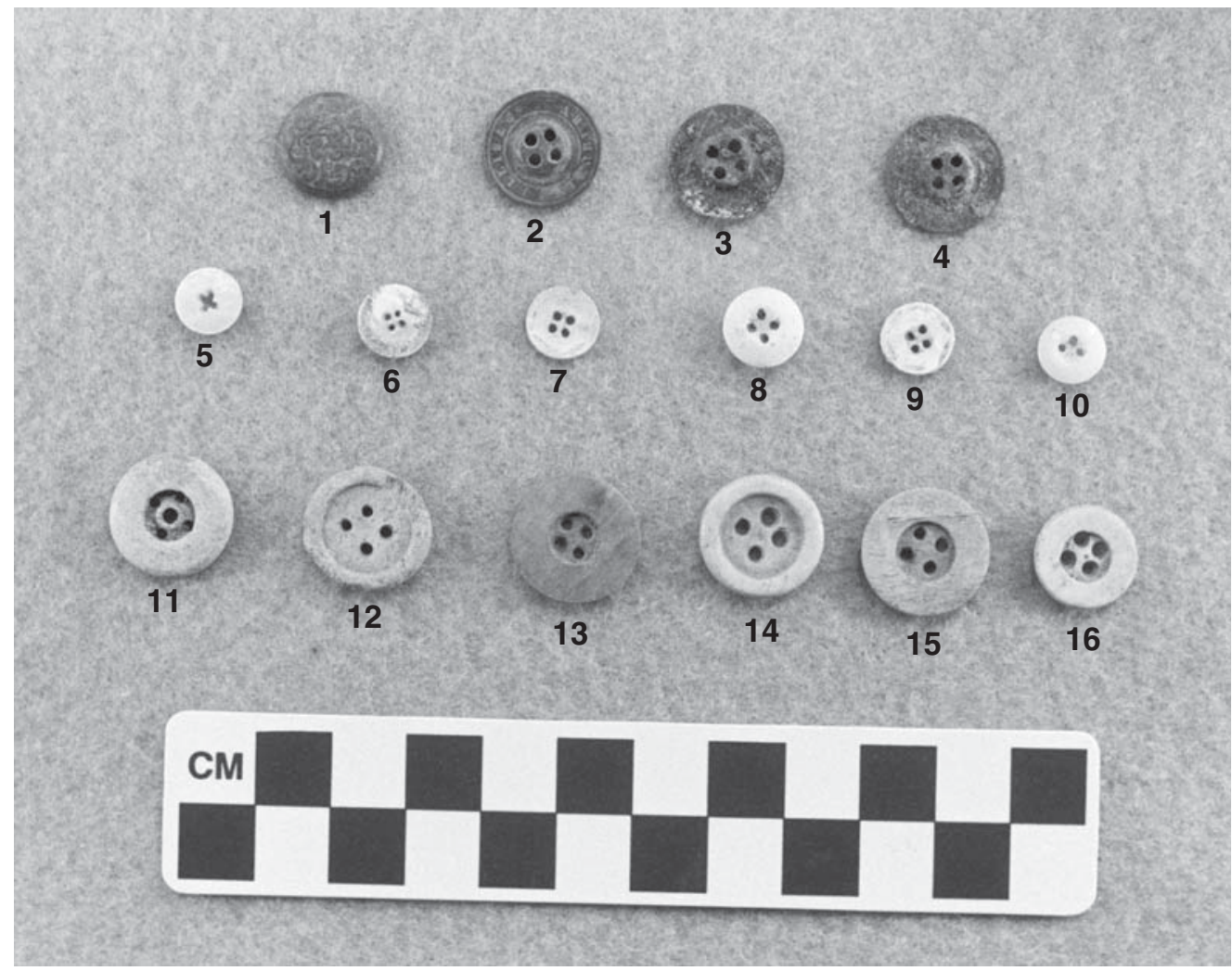

a

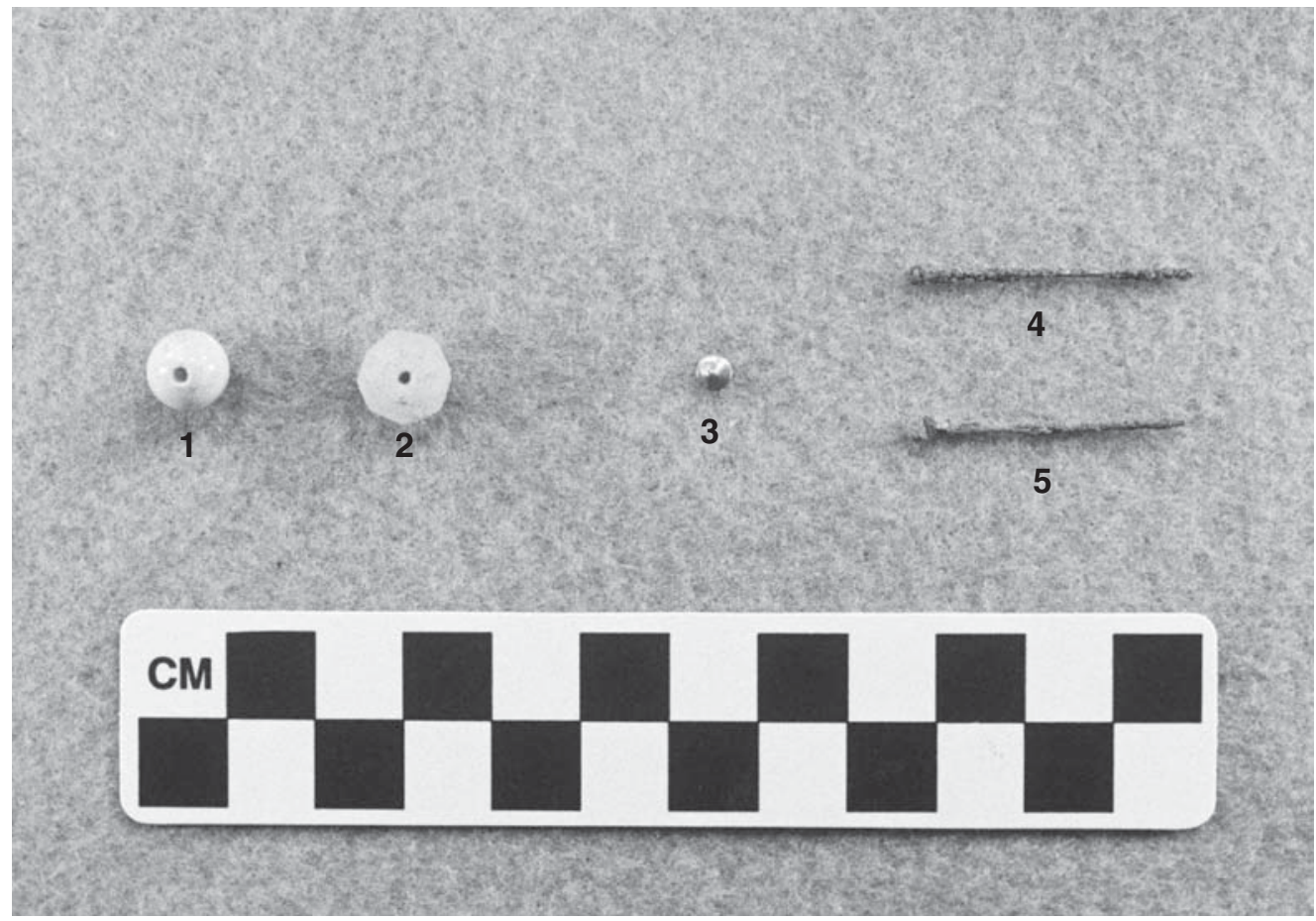

b

Figure 21. Clothing and personal use artifacts from the Monterey Lake site: a, buttons from Feature 2: 1-4, iron and brass buttons; 5-10, ceramic and shell buttons; 11-16, bone buttons; b, glass beads (1-2), silver ornament (3), and pins (4-5) from Feature 2. 


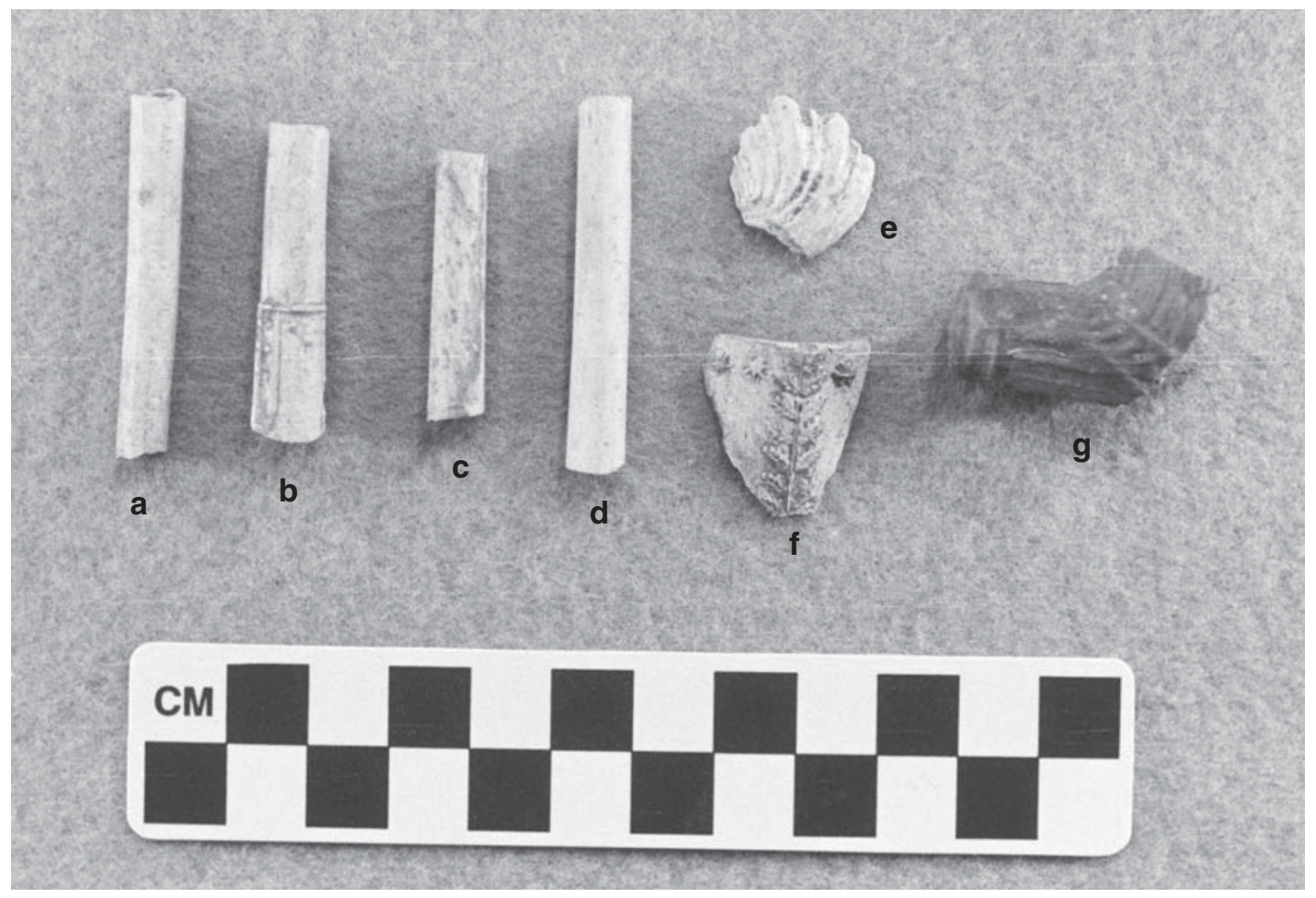

Figure 22. Pipe sherds from Feature 2: a-f, kaolin pipe stem and bowl sherds; g, stoneware pipe sherd.

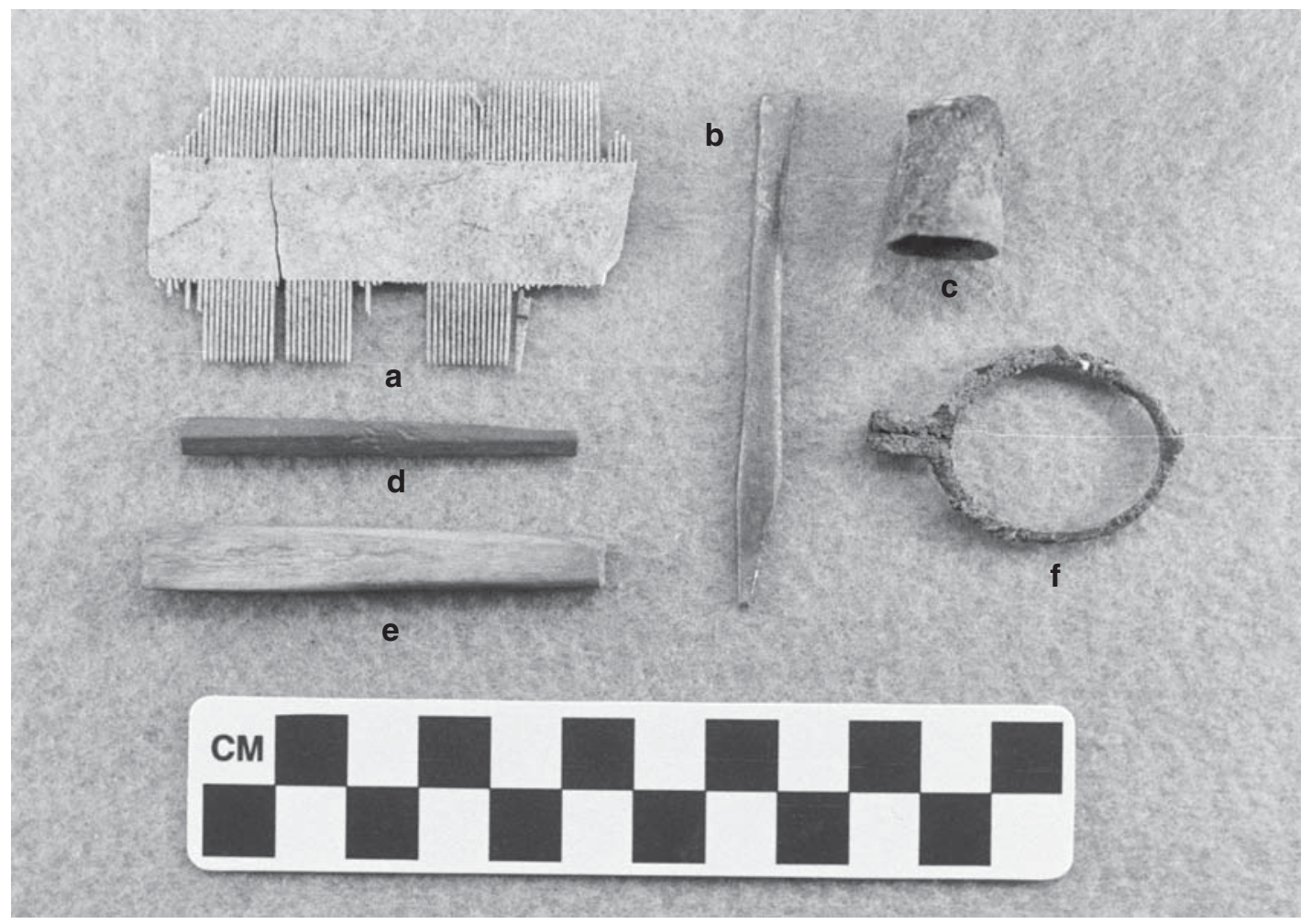

Figure 23. Personal use artifacts from Feature 2: a, bone lice comb; b, e, brass cylinders; c, thimble; d, graphite core for pencil; f, reading glass frame. 
Sulphur River (Perttula 1989:99), both in northeastern Texas. In other words, the presence of glass beads in an early to mid- $19^{\text {th }}$ century archaeological deposit is not necessarily indicative of an Historic Caddo occupation.

The pipe sherds from the Monterey Lake site are from early to mid- $19^{\text {th }}$ century kaolin or ball clay and stoneware forms. The elbow-shaped stoneware pipe, a reed stem pipe with a replaceable reed stem, is mold-made (see Figure 22g), with a ribbed bowl. These sorts of pipes were made at several pottery kilns in the region, including the J. S. Nash factory in operation in Marion County, Texas, between 1850-1880 (Lebo 1988:282). Similar styles of molded elbow pipes have been recovered from 1837 1846 and 1852-1857 Anglo-American farmsteads in northeastern Texas (Nelson and Perttula 2003; Perttula 1989:99).

The $19^{\text {th }}$ century firearm-related artifacts from the Monterey Lake site (Table 8) consist of a number of small caliber lead balls from use in a rifle, a lead flint pad, as well as the accoutrements to make lead balls on site, namely lead bar stock, and lead sprue, the evidence of on-site manufacture (Figure 24a-b). There are also two gunflints (see Figure 15a:2-3), one made from a gray weathered chert and the other from a French honey-yellow-colored chert, and a trigger guard fragment from Feature 2.

There are only two artifacts from the investigations at the Monterey Lake site that can be specifically identified as household furnishings (Table 9). This includes a metal drawer pull and a candle stick holder made of iron (the ring and base) and brass (Figure 25), both discarded in the midden deposits.

The recovered artifacts from the Monterey Lake site also include a small amount of aboriginal lithic and ceramic remains $(n=73)$, primarily lithic debris (Table 10). The plain sherds, grog-tempered, are indicative of either a Woodland period or a Caddo occupation, although the few sherds are not sufficient in and of themselves to argue either that they are associated temporally with the principal historic $19^{\text {th }}$ century occupation at the site, as at $41 \mathrm{MR} 211$ (Parsons et al. 2002). It is just as probable that these plain grog-tempered pottery sherds might be associated instead with the dart points.

The six dart points are contracting stem Gary points. Their recovery indicates some use, if not exclusive use, of the site during the lengthy Woodland period (cf. Schambach 2002). Given the occurrence of diagnostic Woodland period chipped stone tools, the plain grog-tempered sherds here may be best seen as part of this occupation, since grog-tempered pottery is one of the hallmarks of Woodland period material culture in this region of Northeast Texas (Perttula 2004:376).

The faunal remains from the Monterey Lake site are from the early $19^{\text {th }}$ century midden deposits and other associated historic archaeological contexts. These remains include one fish scale from Feature 2, 20+ pieces of egg shell from Feature 2, and 1065 animal bones, among them bones of cow, pig, whitetailed deer, fish, and a canid; some of the bone has butchering marks. These animal bones are from

Table 8. Firearm-related artifacts from the Monterey Lake site.

\begin{tabular}{lcc}
\hline Artifact Description & No. & Comments \\
\hline lead bar stock & 5 & \\
lead strips & 2 & $0.31-0.42$ caliber \\
lead balls & 25 & \\
lead sprue & 5 & \\
lead flint pad & 1 & \\
trigger guard & 1 & 1873-1912, United Metallic \\
percussion cap & 1 & Cartridge Company \\
gunflints & 2 & \\
Shotgun shell & 3 & \\
\hline Total & & \\
\hline
\end{tabular}




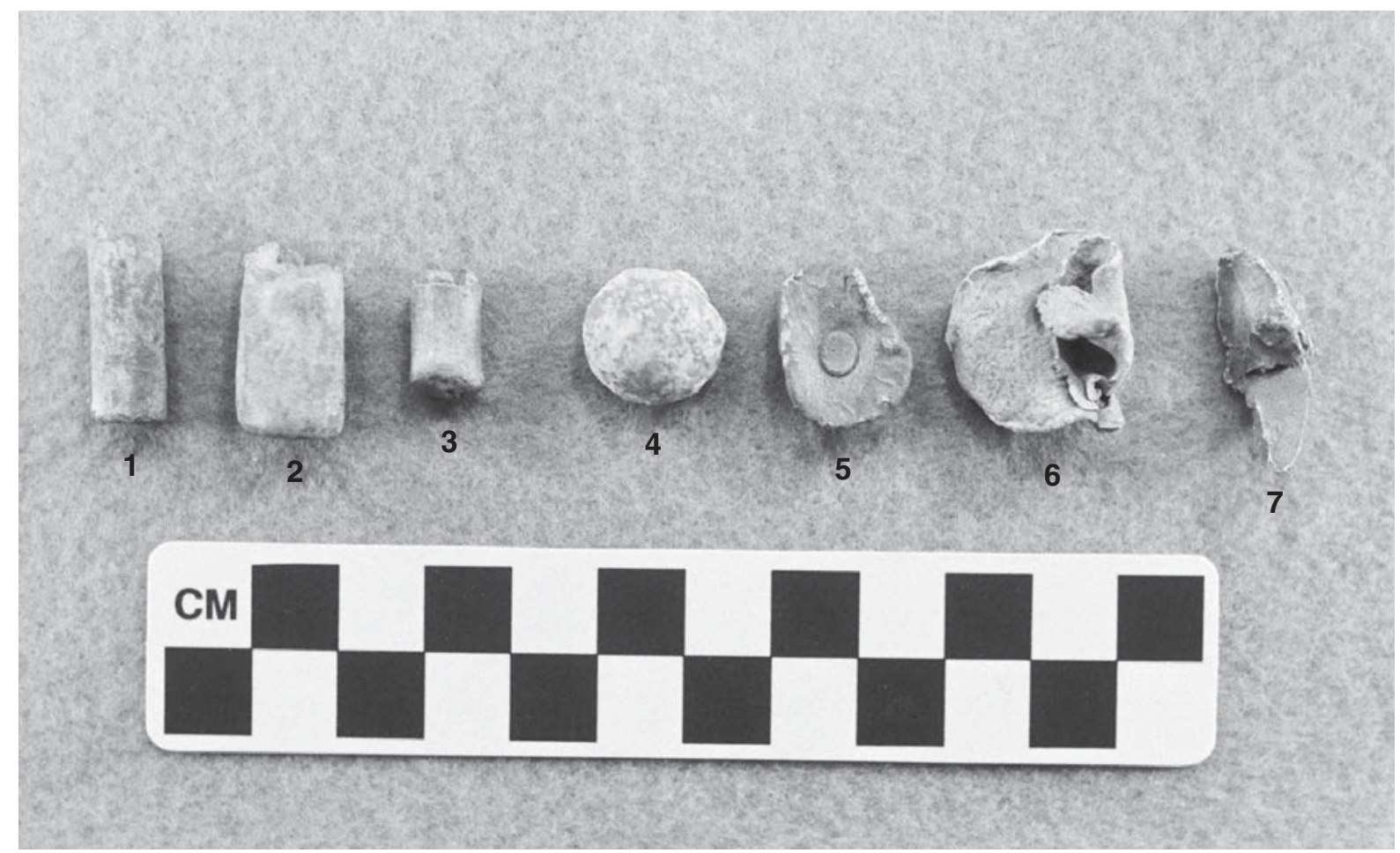

a

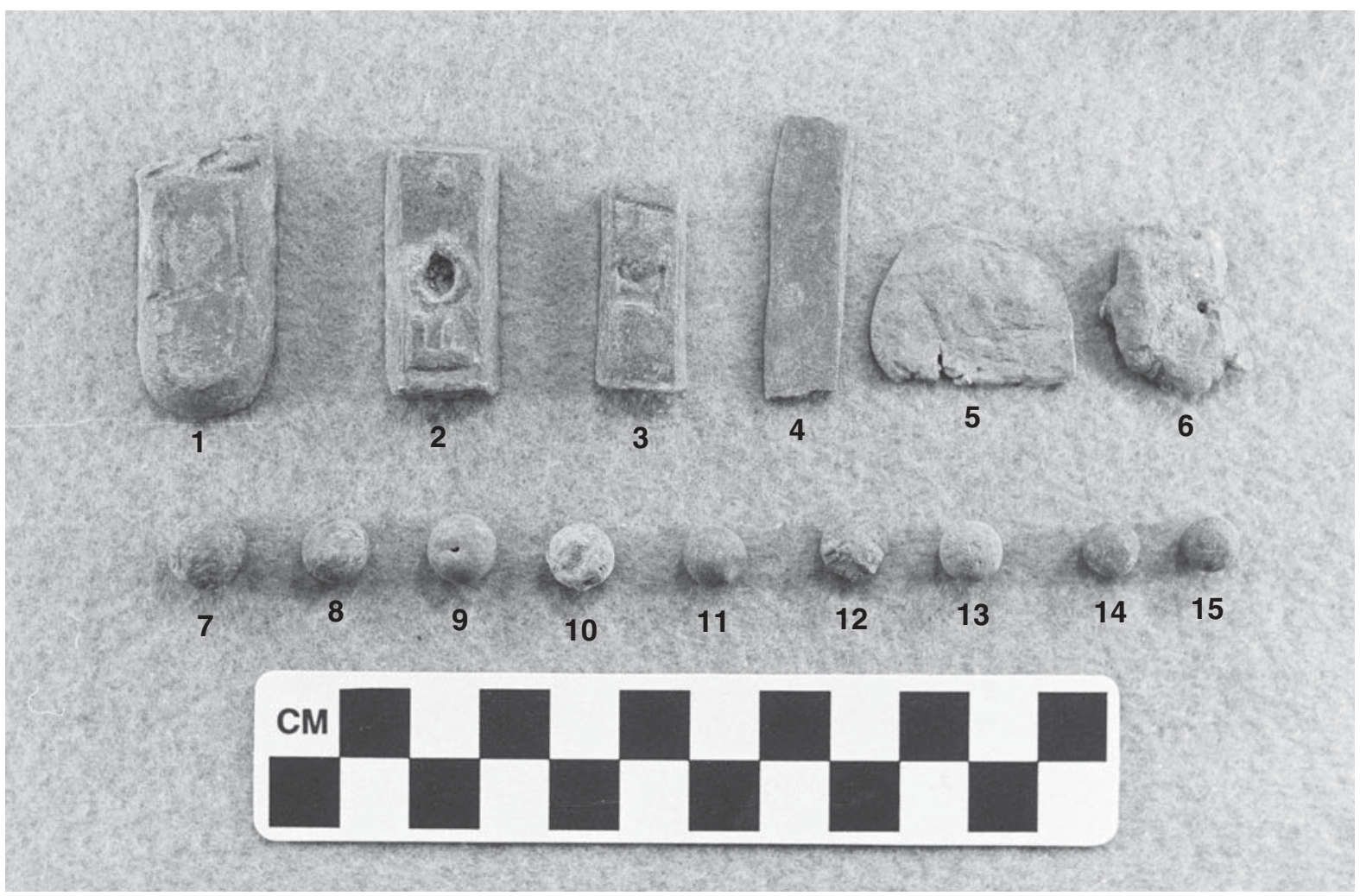

b

Figure 24. Firearm-related artifacts from Feature 2 at the Monterey Lake site: a, lead bar stock (1), lead canisters (2-3), lead balls 4-6), and sprue (7); b, lead bar stock (1-4), flint pad (5), sprue (6), and small caliber lead balls (7-15). 
Table 9. Household Furnishings.

\begin{tabular}{ll}
\hline Artifact Description & No. \\
\hline metal drawer pull & 1 \\
iron and brass candle stick holder & 1 \\
\hline Total & 2 \\
\hline
\end{tabular}

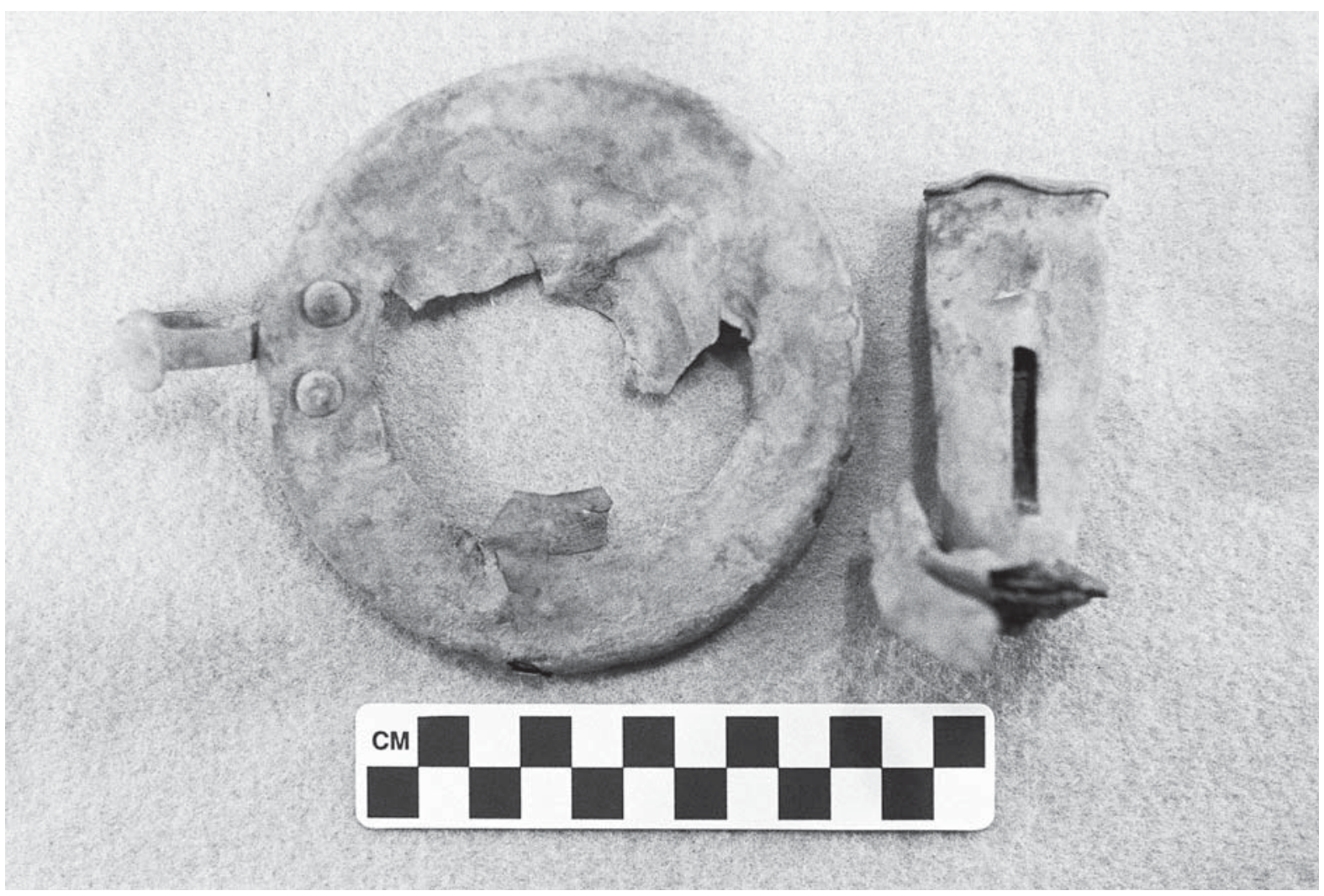

Figure 25. Iron and brass candle stick holder from Unit 1, Monterey Lake site (41MR77).

Table 10. Aboriginal artifacts from the Monterey Lake site.

\begin{tabular}{lc}
\hline Artifact Description & No. \\
\hline lithic debris & 59 \\
lithic core & 1 \\
dart point & 6 \\
ground stone tool & 1 \\
quartz crystal & 1 \\
plain ceramic sherds & 5 \\
\hline Total & 73 \\
\hline
\end{tabular}


Feature $1(\mathrm{n}=153)$ and Feature $2(\mathrm{n}=876)$, and from the shovel tests (see Figure 10b). In the single $1 \mathrm{x}$ $1 \mathrm{~m}$ unit excavated in $10 \mathrm{~cm}$ arbitrary levels in the Feature 2 area (see Figure 7), a total of 430 animal remains were recovered from controlled vertical proveniences: $86 \%$ are from $10-50 \mathrm{~cm}$ bs; $8 \%$ are from $0-10 \mathrm{~cm}$ bs; and $6 \%$ are from $50-70 \mathrm{~cm}$ bs.

\section{Pam Site (41MR78)}

The Pam site is on an upland ridge slope (270 feet amsl) on the north side of the James Bayou valley (see Figure 3). A small test excavation was completed on March 20, 1992, at the Pam site. This unit (of unspecified size and uncertain location on the site) was excavated to $70 \mathrm{~cm}$ bs in an area where historic archaeological materials were noted on the surface of the site.

The recovered artifacts suggest that the unit was placed in an area of a $19^{\text {th }}$ century collapsed mud cat chimney, because there were 86 pieces of hand-made brick and daub in the unit collection. Other artifacts found in the test excavations include two pieces of unglazed (or dry) stoneware sherds, one plain whiteware sherd, two colorless bottle glass sherds, 12 machine cut nails, an iron chain link, spike, and bolt, six pieces of animal bone, and a peach pit.

\section{Monterey \#2, Caddo Parish, Louisiana}

The Monterey \#2 site is on a broad and flat terrace (210-220 feet amsl) on the east side of James Bayou and Monterey Lake (see Figure 2). Archaeological investigations at the Monterey \#2 site took place on March 20, 1992. They consisted of surface collecting and metal detecting scans (Figure 26), with associated excavations to $20 \mathrm{~cm}$ bs.

The investigations at the Monterey \#2 site recovered 143 artifacts, including nine pieces of animal fauna (Table 11). The most common kinds of artifacts are cut nails and window glass $(n=55$, $38 \%$ ), refined earthenware, porcelain, and stoneware sherds $(\mathrm{n}=45,31 \%)$, and bottle and snuff glass $(\mathrm{n}=22,15 \%)$.

The many cut nails (1820-1891) are from a wood structure built on the site, probably a log cabin or an early framed building. It had at least one window; the mean thickness of the window glass suggests the window pane was manufactured in ca. 1864 (cf. Moir 1987:80).

The decorated whiteware and porcelain sherds in the assemblage from the Monterey \#2 site include the following: blue-white-black annular ware $(n=1)$; yellow annular ware $(\mathrm{n}=1)$; polychrome hand-painted $(\mathrm{n}=2)$; flown blue ( $\mathrm{n}=2$, with floral motifs, see Sam-

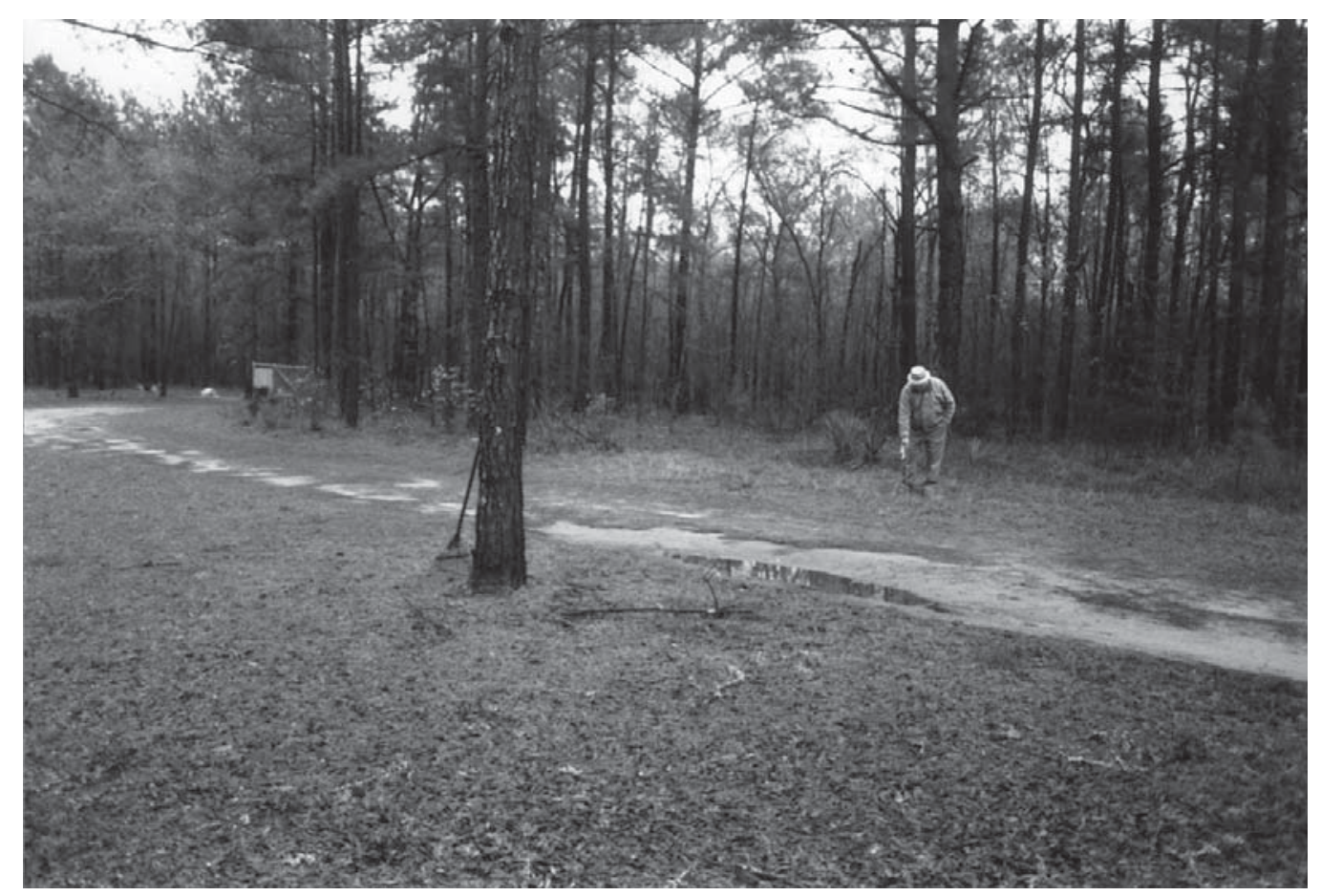

Figure 26. Claude McCrocklin metal detecting at the Monterey \#2 site in Caddo Parish, Louisiana. 
Table 11. Recovered artifacts from the Monterey \#2 site.

\begin{tabular}{lcl}
\hline Artifact Type & No. & Comments \\
\hline salt-glazed stoneware & 1 & \\
yellow ware sherd & 1 & \\
decorated whiteware sherds & 9 & \\
plain whiteware sherds & 33 & \\
decorated porcelain sherd & 1 & 1 purple glass; 1 porcelain \\
milk glass sherd & 1 & \\
snuff container & 1 & \\
bottle glass sherds & 20 & \\
& 2 & \\
buttons & 3 & \\
kaolin pipe sherds & 1 & \\
glass marble & 51 & \\
cut nails and nail shanks & 4 & \\
window glass & 2 & \\
iron stove parts & 1 & \\
iron pin & 1 & \\
iron hinge & 1 & \\
iron nut & & \\
tin can fragments & & \\
faunal remains & & \\
\hline Total & & \\
\hline & & \\
\end{tabular}

ford 2000:79); blue shell-edged $(n=2)$; blue transferprinted (on porcelain, Chinese motif, $\mathrm{n}=1$ ); and red transfer-printed on whiteware $(\mathrm{n}=1)$. The earth-toned annular ware and the floral motifs on the flown blue ceramics are consistent with a ca. 1840-1850s occupation, as are the blue (1784-1859 range of production, and a mean beginning and end production dates of 1817-1834) and red (1818-1880 range of production and an 1829-1842 mean beginning and end production dates) transfer-printed sherds (Samford 2000:Table 5). One of the blue shell-edged plates has an unscalloped rim with impressed lines (ca. 1830-1860), while the other has an unscalloped rim and painted lines (ca. 1860-1890) (Hunter and Miller 1994).

The stoneware sherds in the artifact assemblage include only a salt-glazed body sherd (ca. 18401860) and a ca. 1840-1860s yellow ware handle (see Table 11).
Nineteenth century bottle and snuff glass is relatively abundant at the Monterey \#2 site. It includes aqua-colored glass sherds $(n=9)$ from hand-blown and hand-applied bottles; brown bottle glass $(n=7)$ from a snuff container, a bottle with a glass-tipped pontil, and a third sherd from a paneled bottle; as well as purple (1880-1918, $n=1)$, olive green $(n=2)$, green $(n=1)$, and colorless $(n=1)$ bottle glass sherds.

There are clothing buttons in the artifact collection, a 2-hole purple glass button and a four-hole porcelain button. Personal items at the Monterey \#2 site include three kaolin pipe bowl/stem sherds and a blue glass marble (post-1846 manufacture, see Zapata 1997:109). If the marble was made in the United States, it probably dates after ca. 1880 (Zapata 1997:110), when American glass marble making companies began to be active.

Other domestic artifacts found on the Monterey 
\#2 site include iron stove parts, an iron pin and hinge, and tin can fragments. The milk glass sherd may be from a broken cosmetic container, as it is decorated on one side and has a handle.

\section{Corley \#1 (41MR80)}

The Corley \# 1 site is on a southward to southeastern-trending upland ridge (250-260 feet amsl) on the north side of the James Bayou valley (see Figure 3). The landform is in pasture with a fringe of pine trees and hardwoods along the slopes of the ridge (Figure 27).

Archaeological investigations at the Corley \#1 site included surface collections and metal detecting on March 20 and October 21, 1992, along with shovel testing on January 16, 1993. The 1992 surface collecting and metal detecting was concentrated on the crest of the landform, while aboriginal artifacts (pottery sherds and lithic debris) were found in the northern part of the site (Figure 28). A light scatter of animal bone and historic artifacts were noted on the surface in the southern part of the site. Overall, a wide variety of historic $19^{\text {th }}$ century artifacts were recovered during the investigations at the Corley \#1 site (Table 12).

The principal historic artifacts found at the Corley \#1 site include various structural/architectural remains $(\mathrm{n}=113)$ from a wood-framed structure, including square cut nails (1820-1891, see Wells 2000), daub/fired clay from a mud cat chimney, and window glass; whiteware and porcelain ceramic cups and plates $(n=104)$; and bottle glass $(n=58)$. The thickness of the few pieces of window glass from the site suggest they came from panes of glass manufactured around 1872.

The decorated whiteware sherds at the site, dating from ca. 1830-1860, are dominated by fine-line and polychrome hand-painted cup sherds $(\mathrm{n}=10)$, with smaller amounts of blue annular ware $(n=2)$, red transfer-printed $(n=2)$, and a blue shell-edged plate rim $(\mathrm{n}=1)$. The red transfer-printed sherds have an 1818-1880 range of production and 1829-1842 mean beginning and end production dates (Samford 2000:Table 5). The blue shell-edged plate has an even scalloped rim with impressed lines (ca. 18101835) (Hunter and Miller 1994). A sherd found on the surface of the Corley \#1 site is a whiteware bowl with a "Pearl" impressed maker's mark from an ca. 1840-1868 Wedgwood refined earthenware vessel (Godden 1964:658). The one decorated porcelain has a blue Chinese motif transfer-print.

The bottle glass includes 36 aqua-colored sherds, two with embossed letters, and 11 clear or colorless sherds (two with embossed letters) from paneled bottles, one dark olive green sherd from a

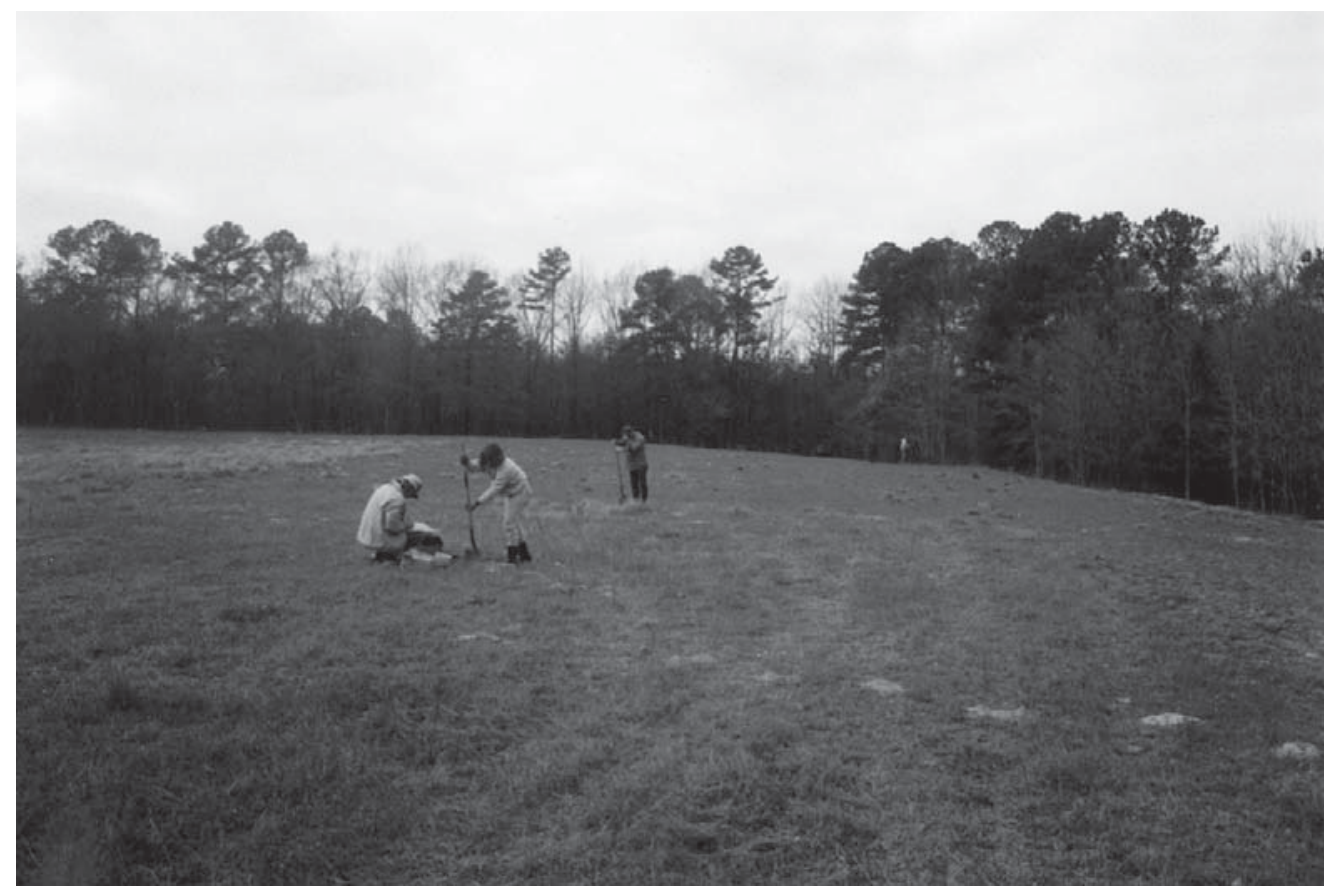

Figure 27. Looking southeast at 1993 shovel testing at the Corley \#1 site. 
38 Journal of Northeast Texas Archaeology 32 (2010)

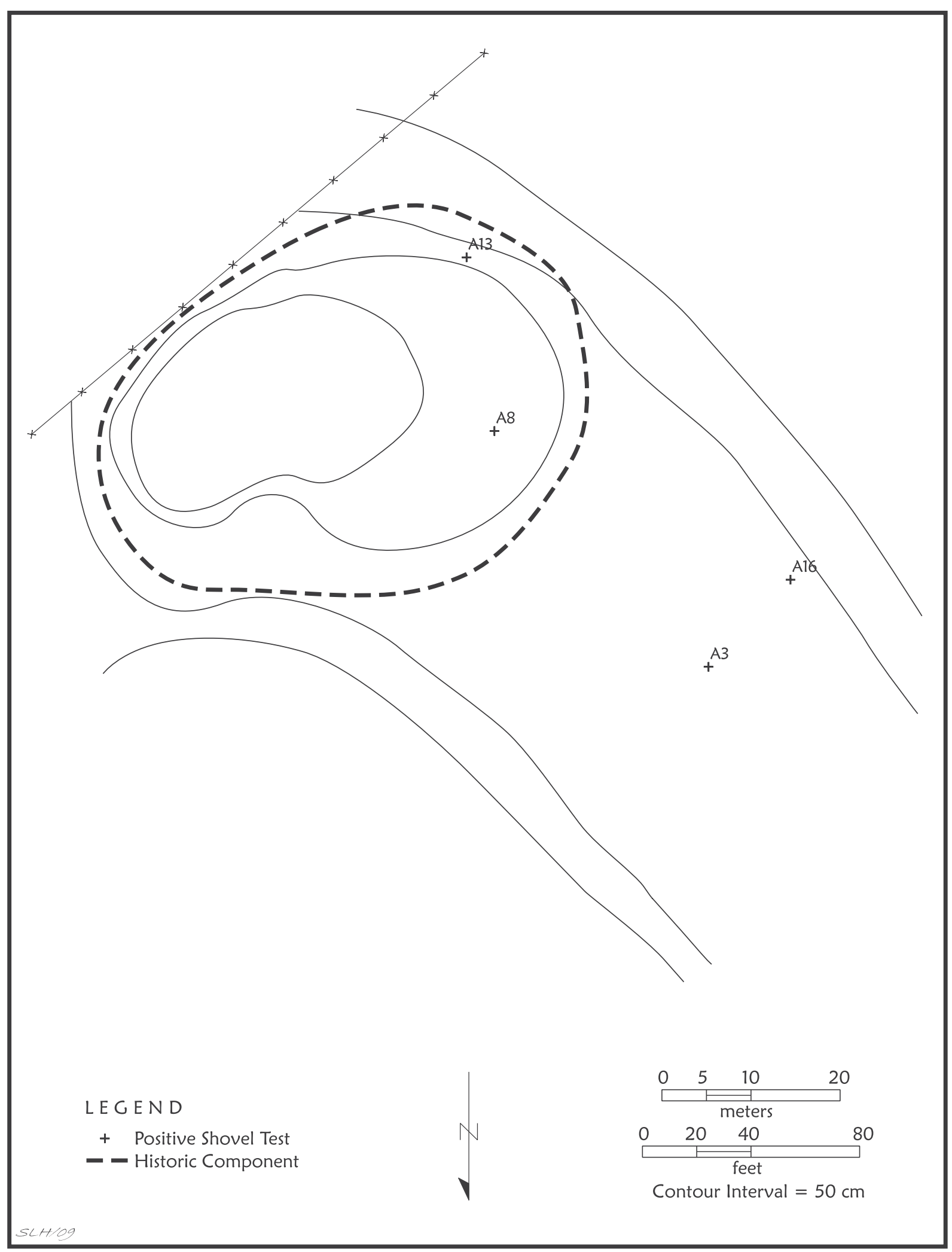

Figure 28. Map of the Conley \#1 site, with the location of positive shovel tests excavated in January 1993. 
Table 12. Recovered artifacts from the Corley \#1 site (41MR80).

\begin{tabular}{|c|c|c|}
\hline Artifact Type & No. & Comments \\
\hline plain whiteware sherds & 87 & \\
\hline decorated whiteware sherds & 15 & \\
\hline whiteware maker's mark & 1 & \\
\hline decorated porcelain sherds & 1 & \\
\hline bottle glass & 58 & \\
\hline ball clay pipe stem & 1 & \\
\hline brass buttons & 3 & \\
\hline brass tack & 1 & \\
\hline daub/fired clay & 60 & \\
\hline cut nails & 49 & \\
\hline window glass & 4 & mean thickness $=1.9 \mathrm{~mm}$ \\
\hline lead balls & 19 & 0.29 to 0.49 caliber \\
\hline lead sprue & 2 & \\
\hline brass patch box & 1 & \\
\hline small hollow lead canisters & 2 & \\
\hline iron axe & 1 & \\
\hline iron wedge & 1 & \\
\hline iron hoe & 1 & \\
\hline iron horseshoe section & 1 & \\
\hline iron buckle & 1 & \\
\hline iron locking mechanism & 1 & \\
\hline iron key & 1 & \\
\hline iron machine part & 1 & \\
\hline unidentified metal rod & 1 & \\
\hline brass lid & 1 & \\
\hline faunal remains & 12 & \\
\hline lithic debris & 1 & \\
\hline aboriginal pottery sherds & 6 & \\
\hline Total & 333 & \\
\hline
\end{tabular}


wine bottle, nine olive green liquor bottles, and one blue glass sherd from a medicinal container. All the glass bottle sherds appear to be from hand-blown bottles. The embossed bottle sherds are from paneled bottles that were made after about 1850 (Newman 1970:74).

Several personal items are among the artifacts found at the Corley \#1 site, among them a ball clay or kaolin clay pipe stem fragment from the surface, as well as a brass clothing button (also from surface contexts) and an iron key (see Table 12). Metal tools are apparently abundant in the archaeological deposits, and these include a large iron axe, an iron hoe, an iron buckle, a section of a horseshoe, and an iron locking mechanism.

Firearms were apparently in use at the site, based on the recovery of a number of lead balls (ranging in size from 0.29-0.49 caliber) from both surface contexts $(n=7)$ and test excavations $(n=12)$. Pieces of a brass patch box (Figure 29) also came from surface contexts at the Corley \#1 site, along with pieces of lead sprue. There were two small hollow lead canisters found in the test excavations (see Table 12).
Aboriginal artifacts from the Corley \#1 site were found in two shovel tests on the northern part of the landform (ST A-3 and ST A-16). This includes one piece of non-cortical claystone/siltstone lithic debris from ST A-16 $(0-20 \mathrm{~cm} \mathrm{bs})$ and six finely grog-tempered sherds from ST A-3 (0-24 $\mathrm{cm} \mathrm{bs)}$. The grog-tempered sherds are lower bodybase sherds with no surface treatment, decoration, or sooting. The thickness of the body sherds (10.0 $\mathrm{mm})$ and the base sherds $(13.4 \mathrm{~mm})$ suggest these sherds are from a vessel of considerable size and volume, probably a cooking or storage jar. The specific cultural or temporal affiliations of these plain grog-tempered sherds is not known, but in the absence of any sherds with decorations, the thickness of the recovered sherds suggests they may be from Woodland to Early Caddo period Williams Plain vessels.

\section{Corley \#2 (41MR81)}

The Corley \#2 site is on an upland ridge slope (260-270 feet amsl) not far north of the Corley \#1 site (see Figure 3). The two sites are separated by a small

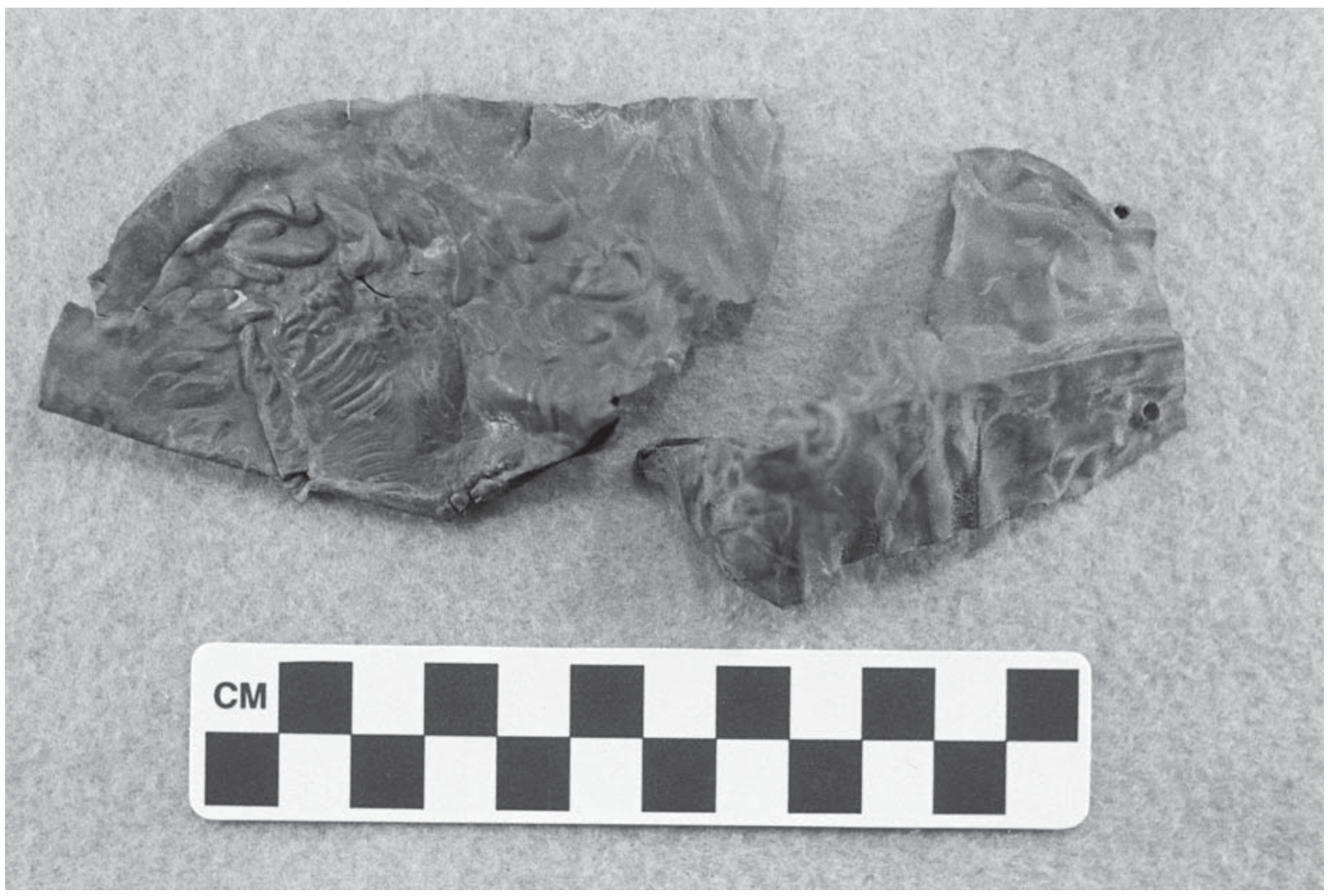

Figure 29. Brass patch box pieces from the Corley \#1 site. 
intermittent stream that dissected the ridge slope and drains to the southeast into the James Bayou floodplain. Surface collections and the excavation of metal detector scans (to depths of $10-30 \mathrm{~cm}$ bs) were completed on January 22, 1992, and February 3, 1992, at the Corley \#2 site. No cultural features were identified in the limited investigations completed at the site; the virtual absence of preserved faunal remains suggests there is no midden deposit here.

The small assortment of ca. 1830-1860 artifacts from the Corley \#2 site are from a domestic occupation, likely a farmstead with a wood structure. That structure was framed using cut nails (18201891) —although the one hand-forged nail (ca. 1769-
1820, Wells 2000:Figure 8) suggests recycling of nails from some earlier structure-had a window, as well as a mud cat chimney or clay plastered log walls. The mean thickness of the window glass suggests the window panes used in the building here were manufactured about 1852 (cf. Moir 1987).

Other artifacts include iron tools, buckets, and cook ware (cast iron kettle and pan fragments), clothing buttons (including overalls), lead balls from the use of a musket, a copper lamp cover, and a number of sherds from ceramic plates and stoneware crocks as well as glass bottles. Among the ceramic sherds are 22 pieces of post- 1830 whiteware plates, including three hand-painted polychrome sherds (see

Table 13. Recovered artifacts from the Corley \#2 site (41MR81).

\begin{tabular}{|c|c|c|}
\hline Artifact Type & No. & Comments \\
\hline alkaline-glazed stoneware & 4 & \\
\hline decorated whiteware sherds & 3 & \\
\hline plain whiteware sherds & 17 & \\
\hline \multicolumn{3}{|l|}{ whiteware sherds with } \\
\hline maker's marks & 2 & \\
\hline bottle glass & 19 & \\
\hline burned clay & 4 & \\
\hline window glass & 2 & mean thickness $=1.65 \mathrm{~mm}$ \\
\hline cut nails & 19 & \\
\hline hand-forged nail & 1 & \\
\hline lead balls & 4 & 0.29 caliber \\
\hline suspender fastener & 1 & \\
\hline brass button & 1 & \\
\hline copper lamp cover and sheet copper & 2 & \\
\hline iron hoe & 1 & \\
\hline iron nut & 1 & \\
\hline iron buckle & 1 & \\
\hline iron bucket handle & 1 & \\
\hline iron kettle fragment & 1 & \\
\hline iron pan base & 1 & \\
\hline faunal remains & 1 & \\
\hline Total & 86 & \\
\hline
\end{tabular}


Table 14) and two 1850s sherds with maker's marks: "IRONSTON..." and "ROYAL CROWN---IRONSTONE CHIN..." The bottle glass includes sherds from purple $(n=2)$, olive green $(n=3)$, colorless $(n=4)$, aqua $(n=6)$, amber $(n=3)$ bottles; there is also a green milk glass sherd from a fruit jar lid liner.

The stoneware recovered from the Corley \#2 site is also consistent with a early to mid-19 $9^{\text {th }}$ century occupation, as it includes four sherds of alkaline-glazed ware. This ware was popular in Texas between ca. 1839-1875, but primarily before the Civil War, and was likely obtained from one of the stoneware pottery kilns in the Jefferson, Texas, area (Lebo 1987:Table 8-1).

\section{Monterey \#3 (41MR82)}

The Monterey \#3 site lies a short distance to the south of the Monterey \#2 and Monterey \#4 sites, on a large and relatively flat terrace (210 feet amsl) on the east side of James Bayou and Monterey Lake (see Figure 2). A surface collection was obtained from the Monterey \#3 site in October and November 1991 from an area that had been recently cleared of vegetation, and consequently surface visibility was good (Figure 30). Follow-up investigations, employing metal detector scans, were completed in March
20, 1992. A large assemblage of artifacts were recovered during the work (Table 14), particularly early to mid- $19^{\text {th }}$ century stoneware and whiteware sherds, machine cut nails, bottle glass, and window glass sherds. A few pieces of lithic debris $(n=6)$ indicate that the site was used at some undefined time during the prehistoric era.

The recovered artifacts from the Monterey \#3 site primarily consist of kitchen/domestic $(n=247$, $70 \%)$ and structural/architectural $(n=80,23 \%)$ remains, of the kinds to be found on a rural farmstead in the Caddo Lake area, especially including plain and decorated whiteware vessel sherds, stoneware sherds, bottle and snuff glass, cut nails (1820-1891, see Wells 2000), and window glass (see Table 14). The mean thickness of the window glass $(1.76 \mathrm{~mm})$ suggests they are from panes of glass manufactured in ca. 1861 (see Moir 1987). There are also clothing items-a porcelain button-toy marbles, and a few miscellaneous pieces of metal in the artifact collections: an iron chain link, an iron strap with a hole, and four cut pieces of brass, one with perforations.

Marbles, both stone and clay, were produced in the United States and elsewhere (especially Germany) in the $18^{\text {th }}$ and $19^{\text {th }}$ centuries. Glass marbles — not present here-were first produced ca.

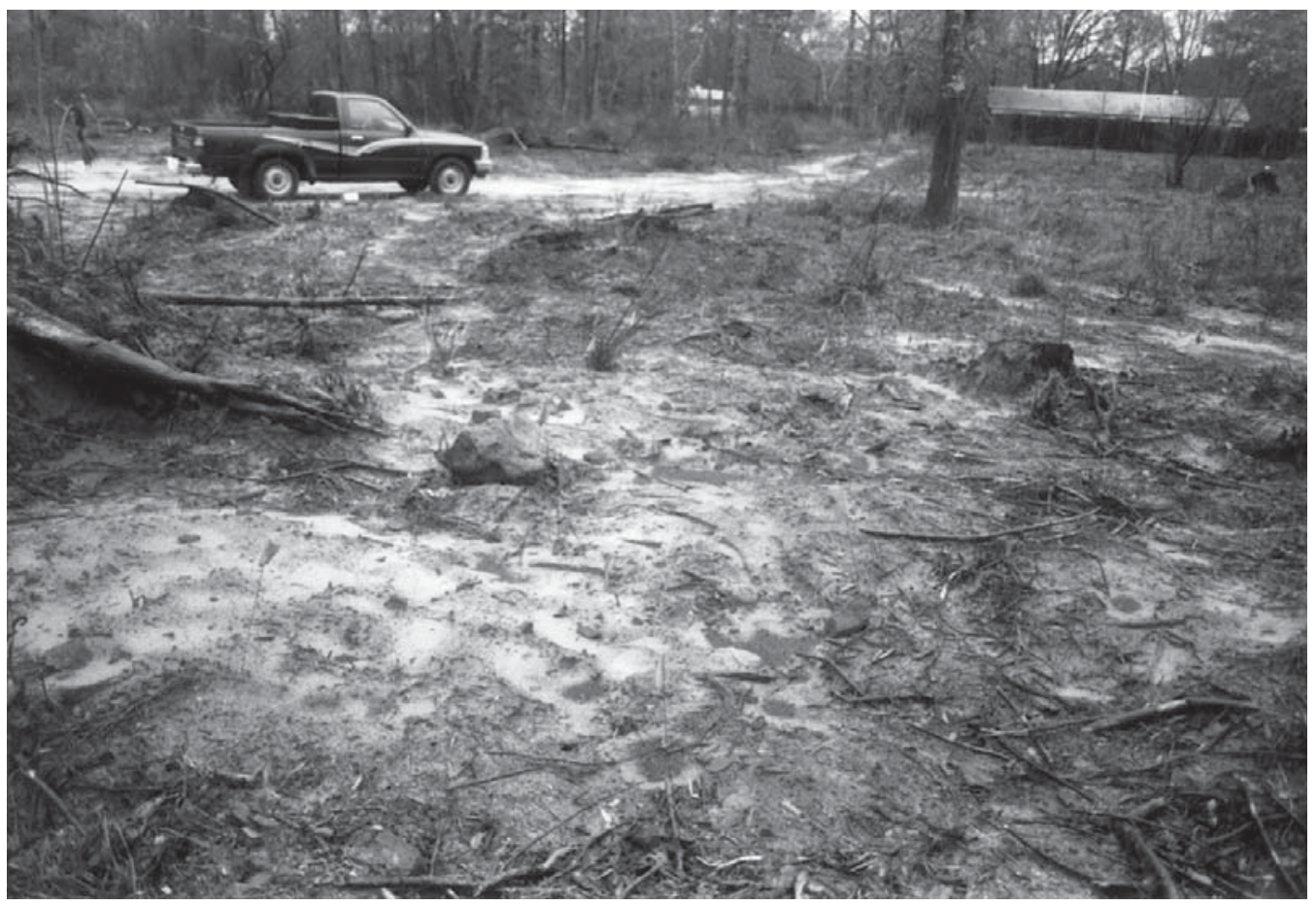

Figure 30. View of the Monterey \#3 site (41MR82) in March 1992. 
Table 14. Recovered artifacts from the Monterey \#3 site.

\begin{tabular}{lcl}
\hline Artifact Type & No. & Comments \\
\hline salt-glazed stoneware sherd & 9 & bottle (n=1) \\
alkaline-glazed stoneware sherds & 8 & \\
Rockingham stoneware sherd & 1 & \\
Yellow ware sherds & 8 & \\
decorated whiteware sherd & 36 & \\
plain whiteware sherds & 133 & \\
whiteware sherd with maker's mark & 2 & I stone; 2 clay \\
redware sherd & 1 & \\
& 1 & \\
porcelain button & 3 & mean thickness, 1.76 mm \\
marbles & 44 & 1 has perforations \\
bottle glass sherds & 5 & \\
snuff glass & 57 & \\
cut nails and shanks & 23 & \\
window glass sherds & 4 & \\
cut brass strips & 1 & \\
iron chain link & 1 & \\
iron strap & 952 & \\
faunal remains & & \\
lithic debris & & \\
\hline Total & & \\
\hline & & \\
& &
\end{tabular}

1846 (Zapata 1997:109), while clay marbles were made between ca. 1840-1920.

The refined earthenware from the Monterey \#3 site include 36 decorated sherds and two with maker's marks. One of the sherds has a "PORC..." mark, while the other has an unidentified impressed back mark. The decorated whiteware sherds include floral relief-molding $(\mathrm{n}=1$, such decorative elements common on whitewares in the 1840 s-1850s, see Price 1979:22); hand-painted $(n=4)$; blue annular ware $(n=3)$; yellow-white-black annular ware $(n=2)$; flown blue $(n=2)$; green transfer-printed $(n=3)$; blue transfer-printed $(n=4)$; purple transfer-printed $(n=1)$; blue shell-edged $(n=3)$ with unscalloped rims and impressed lines (1830-1860, see Hunter and Miller 1994:Plate Vc); and red-green sponge/spatter ware $(n=4)$. The earthy tones of the annular wares suggest these sherds are from early (ca. 1840s) annular ware. Flown blue vessels became popular in the United States in the 1840s-1850s (Samford 2000:79). The date ranges of production of the different colors of transfer-printed ceramics found at the site-blue (1784-1859); green (1818-1859); and purple (1814-1867) — and the fact that these transfer-printed sherds are whitewares-suggests that the occupation at the Monterey \#3 site could have dated most conservatively from ca. 1830-1867. The occurrence of certain kinds of annular ware and flown blue suggests a more likely age range for the occupation at the Monterey \#3 site is ca. 1840-1860.

The one redware sherd from the site has a red lead glaze on both interior and exterior surfaces. 
Redware is not commonly found in Northeast Texas historic ceramic assemblages, and of those, they tend to date no later than the mid-1850s (Perttula 1989:80).

Stonewares include alkaline-glazed $(\mathrm{n}=8$, ca. 1839-1875), Rockingham ( $\mathrm{n}=1)$, salt-glazed $(\mathrm{n}=9$, including a salt-glazed bottle sherd, ca. 1830-1860), and yellow ware ( $n=8$, ca. 1840-1870s). Three of the yellow ware sherds have annular bands of blue, blue and white, and yellow, white, and black. The annular-banded yellow wares were made in the United States or Canada after ca. 1830, but were used extensively from the 1840 s to the 1860 s (Majewski and O'Brien 1984:21)

Bottle glass from the site consists of sherds of amber $(n=1)$, colorless $(n=5$, including a vial lip), olive-green $(\mathrm{n}=9$, including a base with a glasstipped pontil, seen on bottles up to ca. 1870), brown snuff glass $(n=5)$, and aqua $(n=29$, one a vial with a glass-tipped pontil, another with embossing: “... EILIN \& CO", and a third a hand-applied bottle lip) colors. These are from mid- $19^{\text {th }}$ century hand-blown bottles that held liquor or medicine (in vials) with hand-applied lips and four-sided snuff containers with short necks and beveled shoulders. The appearance of embossed lettering of the maker's name on bottles began about 1850 (Newman 1970:74).

\section{Monterey \#4 (41MR83)}

The Monterey \#4 site is located on a flat wooded and/or recently cleared terrace (210 feet amsl) on the east side of Monterey Lake (Figure 31), not far to the northwest of the Monterey \#3 site (see Figure 2 ). At the time of the historic occupation here, the terrace surface would have been between $30-37 \mathrm{ft}$. above the surface of Caddo Lake.

Limited investigations by surface collecting and metal detecting (with finds to depths of $20 \mathrm{~cm} \mathrm{bs}$ ) on November 18, 1991 recovered a small sample of $19^{\text {th }}$ century historic artifacts, including a silver cut-out piece (Figure 32) similar to that seen on other early $19^{\text {th }}$ century aboriginal sites in northwestern Louisiana. This one piece of silver hints at an aboriginal use of the Monterey \#4 site.

Other metal artifacts found at the site include seven machine cut (1820-1891, see Wells 2000) nails and nail shanks, suggesting there was a wood structure constructed on the site, two pieces of lead sprue, 0.63 and 0.64 caliber lead balls, one deformed by impact (see Branstner 2008:Table 1), a piece of iron stock, an iron wedge, an iron chain link, and two later pieces of iron plow parts. The only other recovered artifact is a plain whiteware (post-1830) body sherd.

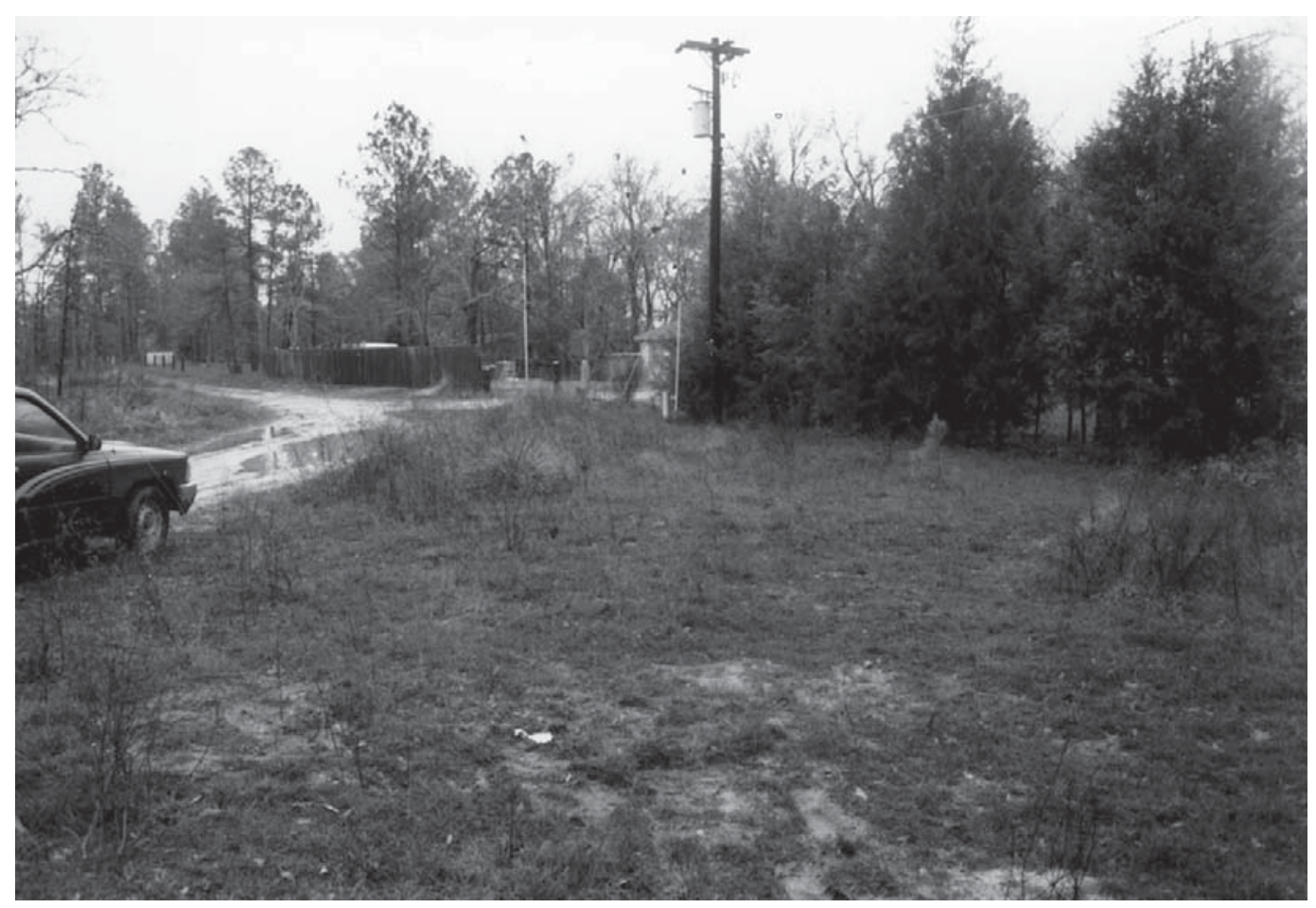

Figure 31. View of the Monterey \#4 site. 


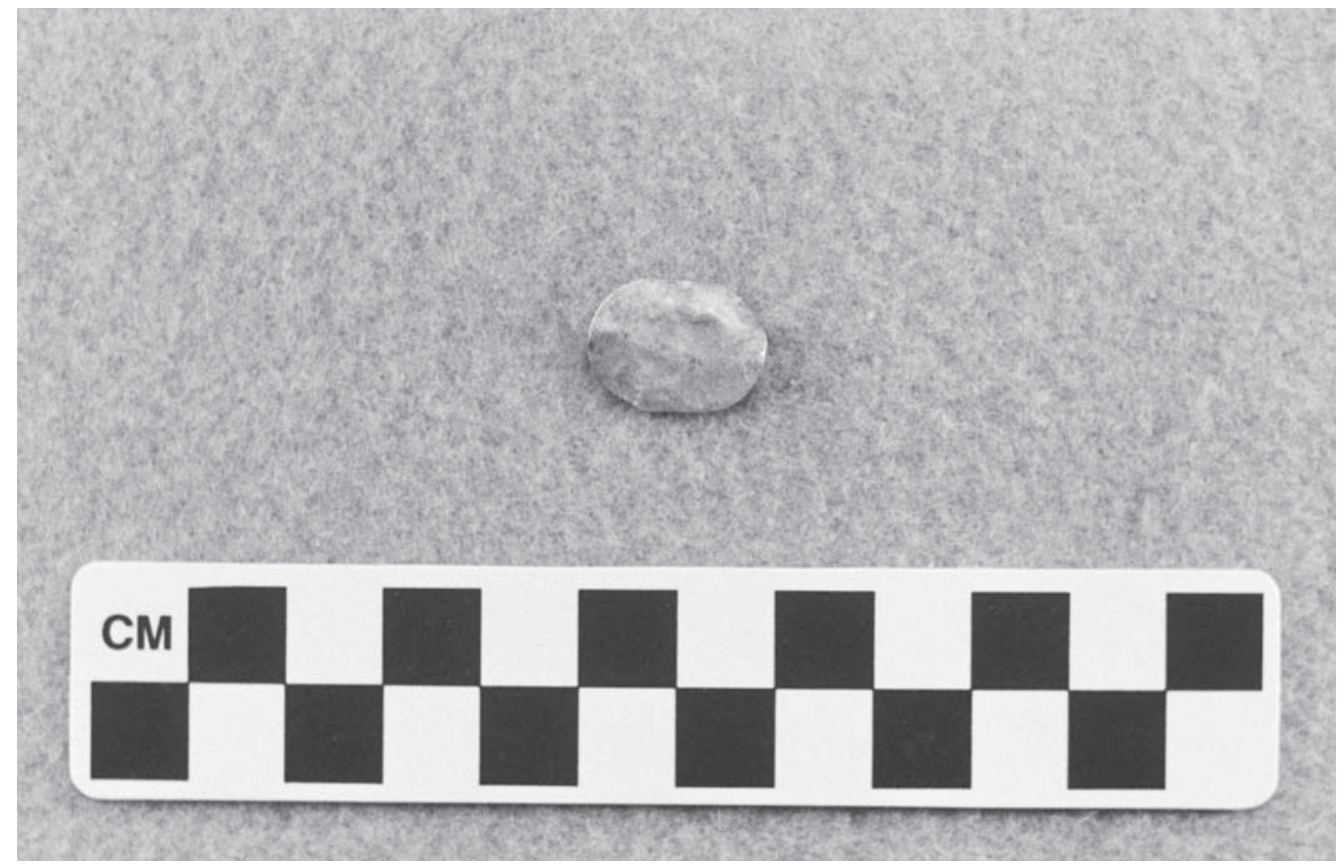

Figure 32. Silver cut-out piece from the Monterey \#4 site.

\section{Monterey \#5 (41MR84)}

The Monterey \#5 site lies on a small toe slope (210 feet amsl) overlooking a broad expanse of the swampy James Bayou floodplain to the west, once part of Caddo Lake (see Figure 2). The site is well north of Monterey Lake, and separated from the Monterey Cemetery by a small drainage area and ravine.

More than 230 artifacts were found at the Monterey \#5 site in January 15, 1992 investigations (presumably from surface collections and screening the fill of metal detector hits). This includes 147 machine cut nails (1820-1891), 20 pieces of hand-made brick, eight miscellaneous pieces of iron, a brass Lshaped handle, nine pieces of whiteware ceramics, one stoneware sherd, 44 pieces of bottle glass, and 10 pieces of animal bone. The many nails and bricks in the collection suggests that there was a $19^{\text {th }}$ century wood structure with a brick chimney at the site.

The ceramics at the site generally date from the ca. 1830s-1860s. Among them is an alkaline-glazed stoneware base sherd (ca. 1839-1875), and five hand-painted whiteware body and rim sherds. The bottle glass includes a light blue flask neck, as well as aqua-colored $(n=1)$, purple $(n=1)$, light green $(n=11)$, dark green $(n=4)$, and very thin colorless $(n=27)$ pieces. The dark green glass is from either a handblown wine bottle or a paneled bottle with embossed letters ("TO..." and "B"); the embossing suggests a manufacture date after ca. 1850 for that bottle. Except for the one later purple bottle glass sherd (ca. 18801918), the other bottle glass sherds are early to mid$19^{\text {th }}$ century in age.

The iron found in the metal detecting work includes a hoe blade, a pad lock, a small hammer head, a hinged metal loop, a hinged metal strap, and screw head, and two wire fence nails.

\section{SUMMARY OF THE ARCHAEOLOGICAL FINDINGS}

The 1991-1993 archaeological investigations along James Bayou in Marion County, Texas, and Caddo Parish, Louisiana, examined a number of early to mid- $19^{\text {th }}$ century sites in the area of a ca. 1800-1840 Caddo village. The search for the $19^{\text {th }}$ century Caddo village on James Bayou continued for several more years, until it was identified in 1998 (McCrocklin 1998; Parsons et al. 2002) on the south side of the bayou (see Figure 3).

The $19^{\text {th }}$ century sites that are the subject of this article include Clements Field (41MR75), 41MR76, Monterey Lake (41MR77), Pam (41MR78), Corley \#1 (41MR80), Corley \#2 (41MR81), Monterey \#2 (Caddo Parish, Louisiana), Monterey \#3 (41MR82), Monterey \#4 (41MR83), and Monterey \#5 (41MR84) (Table 15). Archaeological work 
completed at the sites consisted primarily of metal detecting and surface collections, but shovel tests were done at the Monterey Lake and Corley \#1 sites, and controlled hand excavations were completed at the Monterey Lake and Pam sites.

The Monterey Lake site represents a substantial mid-19 ${ }^{\text {th }}$ century archaeological deposit associated with the 1840 s-late 1870 s village of Monterey on a bluff on the northern end and on the eastern shore of Monterey Lake (Bagur 2001:210215 and Figure 8-14; see Figure 2, this article). The Monterey \#2,\#3, \#4, and \#5 sites are likely also part of the village, or if not, contemporaneous farmsteads associated with commercial establishments at Monterey (see Table 15). This village and steamboat landing (at the western end of the village) had, in addition to homes, a blacksmith shop that had been established in 1847, a mercantile business and saloon, various stores, a sawmill, grist mill, cotton gin, and a large cotton warehouse (Bagur 2001:210). A post office was established here in 1851. By the late 1870s, Monterey was no longer an active steamboat landing or mercantile center on James Bayou. Bagur (2001:215) notes that the last cotton export by boat from Monterey took place in February 1876. In 1878, besides a store, "there were seven or eight vacant houses" at Monterey (Bagur 2001:215).

The other historic Anglo-American sites discussed in this article are north and west along James Bayou (see Figure 3). They appear to be the archaeological remnants of separate farmsteads occupied from the late 1830 s to the 1870 s (see Table 15).

Prehistoric archaeological materials were recovered from several of the James Bayou sites (see Table 15). This includes possible Woodland period (ca. 500 B.C. to ca. A.D. 800) encampments with ceramic sherds and/or stone tools at the Monterey Lake and Corley \#1 sites, and a Late Caddo period (ca. A.D. 1400-1680) settlement at the Clements Field site. Two other sites have lithic debris or ground stone tools from prehistoric occupations of unknown age or character (see Table 15).

Despite our best efforts, none of the sites identified and investigated along James Bayou

Table 15. Selected Characteristics of the James Bayou sites.

\begin{tabular}{|c|c|c|c|}
\hline Site & $\begin{array}{l}\text { Prehistoric } \\
\text { component } \\
\text { (period) }\end{array}$ & $\begin{array}{l}\text { Historic } \\
\text { component } \\
\left(19^{\text {th }} \text { century }\right)\end{array}$ & $\begin{array}{l}\text { Possible pre-1835 } \\
\text { evidence }\end{array}$ \\
\hline Clements Field & Late Caddo & early to mid- $19^{\text {th }}$ & $\begin{array}{l}\text { early green shell- } \\
\text { edged ceramics }\end{array}$ \\
\hline 41MR76 & Unknown & ca. $1840-1875$ & $\begin{array}{l}\text { French faience, } \\
1770- \\
1820\end{array}$ \\
\hline Monterey Lake & Woodland & ca. $1835-1860 \mathrm{~s}$ & $\begin{array}{r}\text { hand-forged nails; } \\
\text { 1810-1835 shell- } \\
\text { edged rim sherds }\end{array}$ \\
\hline Pam & - & ca. $1820-1891$ & - \\
\hline Monterey \#2 & - & ca. $1840-1860 \mathrm{~s}$ & - \\
\hline Corley \#1 & Woodland? & ca. $1840-1870 \mathrm{~s}$ & $\begin{array}{l}\text { 1810-1835 shell- } \\
\text { edged rim sherd }\end{array}$ \\
\hline Corley \#2 & - & ca. $1830 \mathrm{~s}-1860 \mathrm{~s}$ & hand-forged nail \\
\hline Monterey \#3 & Unknown & 1840s-1860s & - \\
\hline Monterey \#4 & - & post-1830s & $\begin{array}{l}\text { silver cut-out piece } \\
\text { and large caliber } \\
\text { lead balls }\end{array}$ \\
\hline Monterey \#5 & - & 1830s-1870s & - \\
\hline
\end{tabular}


between 1991-1993 yielded any concrete evidence for occupation by the Caddo Indian peoples between ca. 1800-1840. The site of Timber Hill (41MR211), on the south side of James Bayou (see Figure 3), was in an area that was not investigated by Claude McCrocklin and his associates until 1998 (McCrocklin 1998), long after the present survey work was concluded. Nevertheless, several of the sites contain a small amount of archaeological material remains-including certain kinds of shell-edged pottery, French faience, hand-forged nails, several large caliber lead balls, and a silver cut-out piece-that hint at use of the area before 1835 (see Table 15). The cultural and ethnic attribution of these specific kinds of material remains has not been determined, but we urge archaeologists interested in the early $19^{\text {th }}$ century history of the Caddo Lake area, especially the early history of Caddo settlement at Caddo Lake, to continue where we left off, and conduct more intensive investigations at these sites, or any new sites identified in this part of James Bayou. Such investigations, however, should not be confined solely to metal detecting, since that tends to overemphasize the recovery of metal artifacts at the expense of the totality of material goods on the site, and lessens the recovery of contextual information from the find spots. Without a representative sample of artifacts, including datable ceramic vessel sherds (including aboriginal Caddo sherds), bottle glass, firearms, and personal use items, etc., along with metal artifacts, recovered in future site investigations, it will be difficult to discern the occupational span of historic archaeological sites along James Bayou or the varied ethnic affiliations of their occupants.

\section{ACKNOWLEDGMENTS}

Volunteers that assisted with the archaeological investigations at one time or another include Charlotte Alford, Harold Brice, Caroline Brown, Wanda Byrd, Julie Connor, M. Edwards, David Hartze, Phillip A. Hartze, Clayton Haskins, Patti Haskins, Rodney Henson, Vernon Holcomb, Vicki Hudson, J. P. Jolly, Craig Kennedy, Marshall McIntosh, Lowell Mickle, Kim and Frank Parks, Mike Patton, Ruth Rainey, Jean Robbins, Tom Speir, Danny Stanfield, David Stanfield, Pam Stanfield, and Mike Turner. We apologize if we have inadvertently forgotten to mention people that helped with the work, but the available records are silent on the names of many of the participants, especially for the work done in January 1993.

Landowners that provided permission to conduct archaeological investigations on their land are John Corley, Johnny Fitzgerald, Robert Harrell, John Haygood, Chubby Jones of the Shingle Mill Hunting Club, C. C. Jones, George Parker, and Danny Stanfield.

Thanks to Mark Armstrong for the information he has provided on renewed archaeological investigations at the Monterey \#4 site.

Bo Nelson took the photographs of the artifacts included in this report, and prepared Figures 2-3. Sandra Hannum prepared the other maps used herein.

\section{END NOTE}

1. These snuff bottles were likely made by E. Roome in Troy, New York, between 1844-1847 (Kwas 2009:114). 


\section{REFERENCES CITED}

Albertson, P. E. and J. B. Dunbar

1993 Geomorphic Investigations of Shreveport to Daingerfield Navigation Project. Technical Report GL-9331. U.S. Army Engineer Waterways Experiment Station, Geotechnical Laboratory, Vicksburg.

Avery, G., H. F. Gregory, J. Emery, and J. Girard

2007 French Faience in Northwest Louisiana. In French Colonial Pottery: An International Conference, edited by G. Avery, pp. 411-469. Northwestern State University Press, Natchitoches, Louisiana.

Bagur, J. D.

2001 A History of Navigation on Cypress Bayou and the Lakes. University of North Texas Press, Denton.

Branstner, M. C.

2008 The Problem with Distorted, Flattened, Spent, and Otherwise Mangled Lead Balls: A Simple Remedy. Illinois Archaeology 20:168-184.

Burrison, J. A.

1975 Alkaline-glazed Stoneware: A Deep South Pottery Tradition. Southern Folklore Quarterly 39(4):377-403.

Castille, G. J., D. B. Kelley, S. K. E. Reeves, and C. E. Pearson

1982 Archaeological Excavations at Esplanade Avenue and North Rampart Streets, New Orleans, Louisiana. Coastal Environments, Inc., Baton Rouge.

Claassen, C.

1994 Washboards, Pigtoes, and Muckets: Historic Musseling in the Mississippi Watershed. Historical Archaeology 28(2):1-145.

Dahmer, F.

1995 Caddo Was... A Short History of Caddo Lake. University of Texas Press, Austin.

Flores, D. L.

1977 The Red River Branch of the Alabama-Coushatta Indians: An Ethnohistory. Southern Studies 16:55-72.

1984 Jefferson and Southwestern Exploration: The Freeman and Custis Accounts of the Red River Expedition of 1806. University of Oklahoma Press, Norman.

Godden, G. A.

1963 British Pottery and Porcelain, 1780-1850. A. S. Barnes and Co., Inc., New York.

1964 Encyclopedia of British Pottery and Porcelain Marks. Barrie \& Jenkins, London, Great Britain.

Greer, G. H.

1981 American Stoneware: The Art and Craft of Utilitarian Pottery. Schiffer Publishing Ltd., Exton, Pennsylvania.
Hunter, R. R. Jr. and G. L. Miller

1994 English Shell-edged Earthenware. Antiques CXLV (No. 3):432-443.

Jones, $\mathrm{O}$.

2000 Glass Bottle Push-Ups and Pontil Marks. In Approaches to Material Culture Research for Historical Archaeologists, compiled by D. R. Brauner, pp. 149-160. $2^{\text {nd }}$ Edition. The Society for Historical Archaeology, California, Pennsylvania.

Jordan, T. G.

1978 Texas Log Buildings: A Folk Architecture. University of Texas Press, Austin.

Kwas, M. L.

2009 Digging for History at Old Washington. University of Arkansas Press, Fayetteville.

Lebo, S. A.

1987 Local Utilitarian Stonewares: A Diminishing Artifact Category. In Historic Buildings, Material Culture, and People of the Prairie Margin: Architecture, Artifacts, and Synthesis of Historic Archaeology, edited by D. H. Jurney and R. W. Moir, pp. 121-142. Volume V. Archaeology Research Program, Institute for the Study of Earth and Man, Southern Methodist University, Dallas.

1988 Local Utilitarian Stoneware Vessels: Developing a Regional Model of Stoneware Use on Farmsteads in Northeastern Texas during the Nineteenth and Early Twentieth Centuries. In Historic farming on the Hogwallow Prairie: Ethnoarchaeological Investigations of the Mountain Creek Area, North Central Texas, compiled by D. H. Jurney, S. A. Lebo, and M. M. Green, pp. 273-297. Joe Pool Lake Archaeological Project, Volume II. Archaeology Research Program, Institute for the Study of Earth and Man, Southern Methodist University, Dallas.

Leibowitz, J.

1985 Yellow Ware: The Transitional Ceramic. Schiffer Publishing Ltd., West Chester, Pennsylvania.

Majewski, T. and M. J. O’Brien

1984 An Analysis of Historical Ceramics from the Central Salt River Valley of Northeast Missouri. Report No. 3. American Archaeology Division, Department of Anthropology, University of Missouri, Columbia.

1987 The Use and Misuse of Nineteenth-Century English and American Ceramics in Archaeological Analysis. In Advances in Archaeological Method and Theory, Volume 11, edited by M. B. Schiffer, pp. 97-209. Academic Press, Inc., New York.

McCrocklin, C.

1991 The Search for Caddo Village (The James Bayou Survey): Preliminary Report, Site 41MR77. MS on file with the author. 
1992a An Intermediate Report on the James Bayou Survey, Marion County, Texas: A Search for Caddo Village. Caddoan Archeology Newsletter 3(3):17-20.

1992b A Preliminary Update of James Bayou Site 41MR76. MS on file with the author.

1998 Preliminary Report on the James Bayou Survey: A Search for Sha-Childni-Ni (1795-1840). Caddoan Archeology 9(1):11-19.

Meissner, B. A.

1997a Making the Man: Remains of Clothing Recovered from the Alamodome Project. In Archaeology at the Alamodome: Investigations of a San Antonio Neighborhood in Transition, Volume III: Artifacts and Special Studies, edited by A. A. Fox, M. Renner, and R. J. Hard, pp. 119-164. Archaeological Survey Report No. 238. Center for Archaeological Research, The University of Texas at San Antonio.

1997b Dolls, Toys, Games, and Other Diversions. In Archaeology at the Alamodome: Investigations of a San Antonio Neighborhood in Transition, Volume III: Artifacts and Special Studies, edited by A. A. Fox, M. Renner, and R. J. Hard, pp. 57-99. Archaeological Survey Report No. 238. Center for Archaeological Research, The University of Texas at San Antonio.

Miller, G. L.

1998 Davenport Date Marks. Victorian Ceramics Group Newsletter 3(3):3-4.

Moir, R. W.

1987 Socioeconomic and Chronometric patterning of Window Glass. In Historic Buildings, Material Culture, and People of the Prairie Margin: Architecture, Artifacts, and Synthesis of Historic Archaeology, edited by D. H. Jurney and R. W. Moir, pp. 73-81. Volume V. Archaeology Research Program, Institute for the Study of Earth and Man, Southern Methodist University, Dallas.

Nelson, B. and T. K. Perttula

2003 Archeological Survey along the Lake Bob Sandlin Shoreline, Camp, Franklin, and Titus Counties, Texas. Report of Investigations No. 46. Archeological and Environmental Consultants, LLC, Austin.

Newman, T. S.

1970 A Dating Key for Post-Eighteenth Century Bottles. Historical Archaeology 4(1):70-75.

Parsons, M. L., J. E. Bruseth, J. Bagur, S. E. Goldborer, and C. McCrocklin

2002 Finding Sha'chahdinnih (Timber Hill): The Last Village of the Kadohadacho in the Caddo Homeland. Archeological Report Series No. 3. Texas Historical Commission, Austin.
Perttula, T. K.

2004 The Prehistoric and Caddoan Archeology of the Northeastern Texas Pineywoods. In The Prehistory of Texas, edited by T. K. Perttula, pp. 370-407. Texas A\&M University Press, College Station.

Perttula, T. K., with contributions by Tom Middlebrook, Bo Nelson, and LeeAnna Schniebs

2008 Archeological Investigations at the D'Ortolan Site (41NA299) and other Late $18^{\text {th }}$ Century to Early $20^{\text {th }}$ Century Sites along Bayou Loco in western Nacogdoches County, Texas. Report of Investigations No. 63. Archeological \& Environmental Consultants, LLC, Austin.

Perttula, T. K. (editor)

1989 The James Franks Site (41DT97): Excavations at a Mid-Nineteenth Century Farmstead in the South Sulphur River Valley, Cooper Lake Project, Texas. Contributions in Archaeology No. 7. Institute of Applied Sciences, University of North Texas, Denton.

Pollan, S. D., W. S. Gross, A. C. Earls, J. T. Pollan, Jr., and J. L. Smith

1996 Nineteenth-Century Transfer-Printed Ceramics from the Townsite of Old Velasco (41BO125), Brazoria County, Texas: An Illustrated Catalogue. Prewitt and Associates, Inc., Austin.

Price, C. R.

1979 Nineteenth Century Ceramics in the Eastern Ozark Border Region: An Analysis of Refined Earthenware from Selected Sites in the Ozark Border Region of Southeast Missouri. Monograph Series No. 1. Center for Archaeological Research, Southwest Missouri State University, Springfield.

Samford, P. M.

2000 Response to a Market: Dating English Underglaze Transfer-Printed Wares. In Approaches to Material Culture Research for Historical Archaeologists, compiled by D. R. Brauner, pp. 56-85. $2^{\text {nd }}$ Edition. The Society for Historical Archaeology, California, Pennsylvania.

Schambach, F. F.

2002 Fourche Maline: A Woodland Period Culture of the Trans-Mississippi South. In The Woodland Southeast, edited by D. G. Anderson and R. C. Mainfort, Jr., pp. 91-112. University of Alabama Press, Tuscaloosa.

Shira, A.

1913 The Mussel Fisheries of Caddo Lake and the Cypress and Sulphur Rivers of Texas and Louisiana. Economic Circular 6. Bureau of Fisheries, Washington, D.C. 
Sussman, L.

2000 British Military Tableware, 1760-1830. In Approaches to Material Culture Research for Historical Archaeologists, compiled by D. R. Brauner, pp. 44-55. $2^{\text {nd }}$ Edition. The Society for Historical Archaeology, California, Pennsylvania.

Tiller, J.

2007 The Shreveport Caddo, 1835-1838. Journal of Northeast Texas Archaeology 26:159-167.

2008 Was Timber Hill the Last Caddo Village in the Caddo Homeland? Caddo Archeology Journal 18:11-21.

Torbenson, M., R. H. Kelly, J. Erlen, L. Cropcho, M. Moracca,

B. Beiler, K. N. Rao, and M. Virji

2000 Lash's: A Bitter Medicine: Biochemical Analysis of an Historical Proprietary Medicine. Historical Archaeology 34(2):56-64.

U.S. Department of the Interior, General Land Office

1914 Examination of Ferry (Caddo) Lake. 3 Vols. U.S. Department of the Interior, General Land Office, Washington, D.C.
Wells, T.

2000 Nail Chronology: The Use of Technologically Derived Features. In Approaches to Material Culture Research for Historical Archaeologists, compiled by D. R. Brauner, pp. 318-339. $2^{\text {nd }}$ Edition. The Society for Historical Archaeology, California, Pennsylvania.

Wyckoff, D. G.

1984 United States Military Buttons of the Land Services 1787-1902. McLean County Historical Society, Bloomington, Illinois.

Zapata, J. E.

1997 Alamodome and Abroad: A Composite Inquiry on Toy Marbles. In Archaeology at the Alamodome: Investigations of a San Antonio Neighborhood in Transition, Volume III: Artifacts and Special Studies, edited by A. A. Fox, M. Renner, and R. J. Hard, pp. 100-118. Archaeological Survey Report No. 238. Center for Archaeological Research, The University of Texas at San Antonio. 